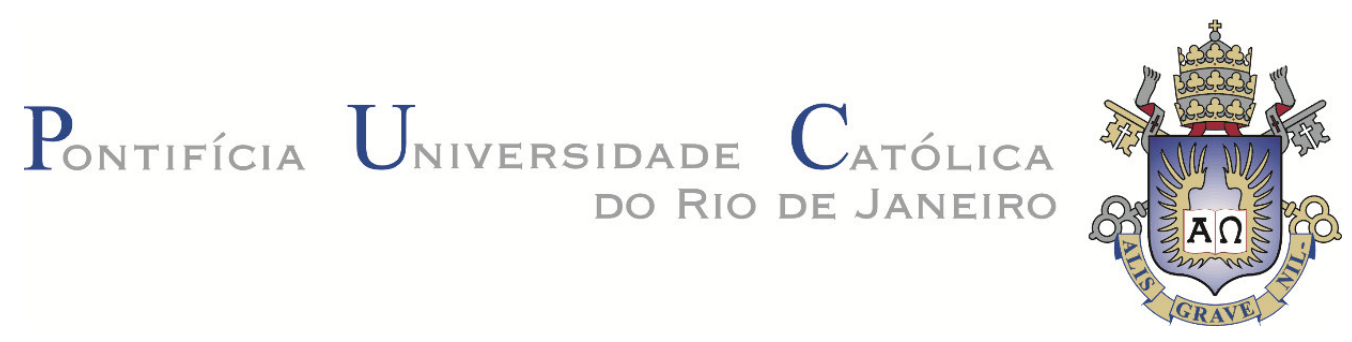

Paula Renata Lobo Brantes

\title{
Análise de Estabilidade de Poços em Trechos de Folhelhos
}

\section{Dissertação de Mestrado}

Dissertação apresentada ao Programa de Pós-graduação em Engenharia Civil da Pontifícia Universidade Católica do Rio de Janeiro como requisito parcial para obtenção do grau de Mestre em Engenharia Civil.

Orientador: Prof. Sérgio Augusto Barreto da Fontoura 


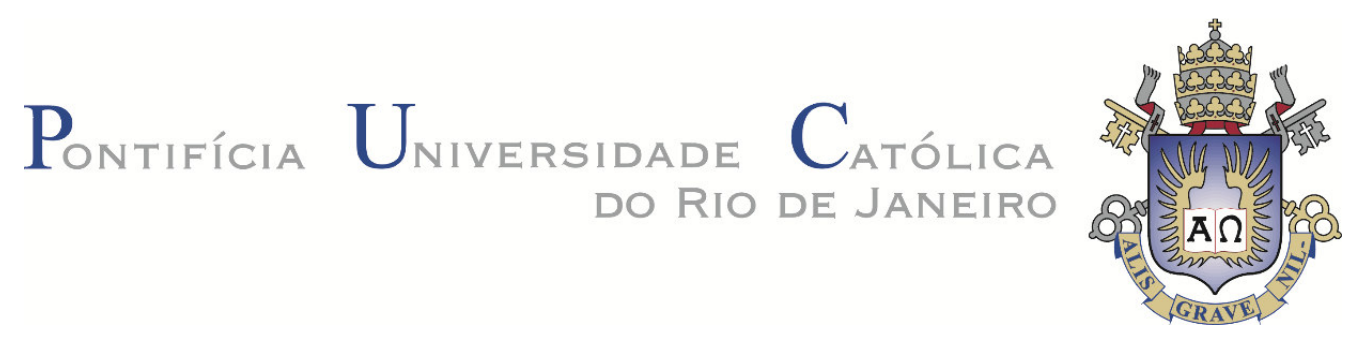

Paula Renata Lobo Brantes

\section{Análise de Estabilidade de Poços em Trechos de Folhelhos}

Dissertação apresentada como requisito parcial para obtenção do grau de Mestre pelo Programa de Pós-Graduação em Engenharia Civil da PUC-Rio. Aprovada pela Comissão Examinadora abaixo assinada.

Prof. Sergio Augusto Barreto da Fontoura Orientador

Departamento de Engenharia Civil e Ambiental- PUC-Rio

Prof ${ }^{\text {. Raquel Quadros Velloso }}$

Departamento de Engenharia Civil e Ambiental- PUC-Rio

\section{Drª. Rosana Fátima Teixeira Lomba PETROBRAS}

Prof. Márcio da Silveira Carvalho Coordenador Setorial do Centro Técnico Científico - PUC-Rio

Rio de Janeiro, 20 de abril de 2018. 
Todos os direitos reservados. É proibida a reprodução total ou parcial do trabalho sem autorização do autor, do orientador e da universidade.

\section{Paula Renata Lobo Brantes}

Graduou-se em Engenharia Civil pela PUC - Rio (Pontifícia Universidade Católica do Rio de Janeiro) no Rio de Janeiro, em julho de 2015. Ingressou no mestrado na PUC-Rio em 2015, desenvolvendo dissertação na linha de pesquisa de Geomecânica do Petróleo.

Ficha Catalográfica

Brantes, Paula Renata Lobo

Análise de estabilidade de poços em trechos de folhelhos / Paula Renata Lobo Brantes ; orientador: Sérgio Augusto Barreto da Fontoura. - 2018.

127 f. : il. color. ; $30 \mathrm{~cm}$

Dissertação (mestrado)-Pontifícia Universidade Católica do Rio de Janeiro, Departamento de Engenharia Civil, 2018.

Inclui bibliografia

1. Engenharia civil - Teses. 2. Folhelho. 3. Estabilidade de poços. 4. Transporte de massa. 5. Ensaio de difusão. 6. Análise físico-química. I. Fontoura, Sérgio Augusto Barreto da. II. Pontifícia Universidade Católica do Rio de Janeiro. Departamento de Engenharia Civil. III. Título.

CDD: 624 
À minha família. 


\section{Agradecimentos}

Neste mundo nada se conquista sozinho. Sempre houve e haverá, em alguma circunstância, a contribuição de uma ou mais pessoas possibilitando a realização dos objetivos. Esta dissertação não é exceção.

Portando, gostaria de agradecer, primeiramente, à Deus pela força, fé e bênçãos que auxiliam em todo caminhar da minha vida. Agradeço a Nossa Senhora pela forte interseção a mim concedida.

À CAPES e a PUC-Rio pela concessão da bolsa de estudos, sem os quais este trabalho não poderia ter sido realizado.

Ao professor Sérgio A. B. Fontoura, meu profundo respeito e admiração profissional. Obrigada pelos ensinamentos, pelo apoio, confiança e oportunidade de desenvolver este trabalho junto ao GTEP.

Aos colegas do GTEP, em especial à Cássia Castelo, Francisco Fontoura, Sandra Rosero, Victor Meléndez e Wethya Alves pela ajuda, apoio e pelas gratas experiências vividas ao longo deste período.

Ao CENPES-Petrobras, em especial a Dra. Rosana F. T. Lomba e ao Ângelo M. Vianna pelos ensinamentos transmitidos e experiências compartilhadas.

À minha família, por ser a minha maior base e meu maior apoio durante todo o meu caminhar. Em especial aos meus pais, Amilton e Vânia, e aos meus irmãos Leonardo e Rafael que, sem dúvida, foram os meus exemplos de seres humanos. Todos os meus logros são por vocês e para vocês, hoje e sempre. 
À Alexandre, por seu sincero amor, por estar ao meu lado nos dias de luta, por me acalmar nos momentos difíceis e por celebrar meus sucessos como se fossem seus. Obrigada por todos esses anos maravilhosas de carinho e amor e por preencher minha vida de alegria com suas ocorrências.

A todos os amigos que conquistei durante o mestrado. Em especial à Claudia Dominoni, Thais Klein, Rebecca Cobe e Ciro Tessari por todos os momentos que compartilhamos de amizade e companheirismo e que vem se tornando ainda mais forte.

A todos os professores e funcionários do Departamento de Engenharia Civil pelos ensinamentos e conhecimentos transmitidos, meu muito obrigado.

Aos professores que participaram da Comissão Examinadora pelas sugestões feitas. 


\section{Resumo}

Brantes, Paula Renata Lobo; Fontoura, Sérgio Augusto Barreto da. Análise de Estabilidade de Poços em Trechos de Folhelhos. Rio de Janeiro, 2018. 127p. Dissertação de Mestrado - Departamento de Engenharia Civil e Ambiental, Pontifícia Universidade Católica do Rio de Janeiro.

Os problemas de instabilidades de poços geralmente ocorrem quando camadas de folhelhos são perfuradas. O processo de instabilidade de poços é o resultado de fenômenos mecânicos e físico-químicos. As instabilidades mecânicas podem ser prevenidas e controladas mediante a otimização do peso do fluido de perfuração. Diferente destas, as instabilidades físico-químicas são dificilmente controláveis e mais complexas, pois além de possuírem várias variáveis, dependem do tempo. Neste sentido, o presente trabalho tem como objetivo analisar e compreender os casos de instabilidade do poço através de uma metodologia que integre os resultados de campo e análises em laboratórios a fim de propor fluidos economicamente mais viáveis e competentes que atuem na estabilidade físicoquímica em trechos de folhelho. Primeiramente são identificados os problemas de instabilidade de um poço (estudo de caso) e seus possíveis agentes causadores através das análises de Boletim Diário de Perfuração (BDP), dados de perfis e análise de estabilidade considerando o modelo elástico. Com base nos problemas identificados, são propostos fluidos hipotéticos de solução salina. Em seguida, amostras de testemunho do poço são coletadas, caracterizadas e analisadas em laboratório com o objetivo de obter os parâmetros de transporte de massa quando estas são submetidas aos fluidos hipotéticos. Por fim, são geradas as análises de estabilidade considerando efeitos físico-químicos conforme tempo de exposição aos fluidos salinos hipotéticos a fim de garantir a otimização do projeto do fluido de perfuração e a estabilidade do poço no processo de perfuração.

\section{Palavras-chave}

Folhelho; boletim diário de perfuração; estabilidade de poços; fluido de perfuração; transporte de massa; ensaio de difusão; análise físico-química 


\section{Abstract}

Brantes, Paula Renata Lobo; Fontoura, Sérgio Augusto Barreto da. (Advisor). Wellbore Stability Analysis in Shales Stretches. Rio de Janeiro, 2018. 127p. Dissertação de Mestrado - Departamento de Engenharia Civil e Ambiental, Pontifícia Universidade Católica do Rio de Janeiro.

Wellbore instability problems usually occur when shale rocks are drilled. The process of wellbore instability is the result of mechanical and physicochemical effects. Mechanical instabilities can be prevented and controlled by optimizing the weight of the drilling fluid. On the other hand, physicochemical instabilities are more complex and difficult to control, because aside from having several variables, they are time-dependent. In this sense, this work has the objective of analysing and understanding the wellbore instability through a methodology that integrates the field results and laboratories' analyses in order to propose competent and economically more viable drilling fluids to act in the physicochemical stability in shale stretches. First, the instability problems of a study case and its main causative agents are identified through Drilling Daily Report analyses, profile data and stability analyses considering the elastic model. Based on the problems identified, hypothetical saline fluids are proposed. Then, well samples are collected, characterized and analysed in laboratory in order to obtain its mass transporting parameters when samples are submitted to hypothetical fluids. Finally, stability analyses is performed considering physicochemical effects according to the exposure time to hypothetical saline fluids in order to guarantee the optimization of the drilling fluid design and the stability of the well in the drilling process.

\section{Keywords}

Shales; daily drilling report; wellbore stability; drilling fluids; mass transporting; difusion tests; physical-chemical analysis 


\section{Sumário}

1 Introdução

1.1 Motivação 19

$\begin{array}{lll}1.2 & \text { Objetivo } & 20\end{array}$

$\begin{array}{lll}1.3 & \text { Estrutura da dissertação } & 21\end{array}$

2 Revisão bibliográfica 23

$\begin{array}{lll}2.1 & \text { Introdução } & 23\end{array}$

2.2 Problemas de Perfuração em Poços 23

2.2.1 Perda de Circulação 24

2.2.2 Kick 25

2.2.3 Desmoronamento do Poço 25

2.2.4 Alargamento do Poço 26

2.2.5 Má Limpeza do Poço 27

2.2.6 Packer Hidráulico (Pack-off) 27

2.2.7 Fechamento do Poço 28

2.2.8 Torque e Drag Elevados 29

2.2.9 Repasse 29

2.3 Identificação de Problemas do Poço 30

2.4 Causas de Instabilidade em Folhelhos 32

2.4.1 Fatores Mecânicos $\quad 34$

2.4.2 Fatores Físico-Químicos 35

2.5 Folhelho e Suas Características $\quad 35$

2.5.1 Tipos de Argilominerais 36

2.5.2 Permeabilidade 36

2.5.3 Inchamento e Dispersão 37

2.6 Fluido de Perfuração 38

2.6.1 Classificação dos Fluidos de Perfuração 39

2.7 Interação Rocha-Fluido 42 
2.7.1 Mecanismo de Transporte 42

2.7.2 Efeito da permeabilidade 48

2.7.3 Efeito de Interação Rocha-Fluido na Estabilidade do Poço 48

3 Identificação dos Problemas de Instabilidade do Poço 50

3.1 Introdução 50

3.2 Metodologia 51

3.2.1 Análise do BDP 51

3.2.2 Análise dos Perfis 53

3.2.3 Análise de Estabilidade 54

3.3 Análise e Resultado 67

3.4 Considerações Finais 78

4 Análise de Testemunho em Laboratório 80

4.1 Introdução $\quad 80$

4.2 Caracterização do Folhelho 81

4.2.1 Análise Granulométrica 81

4.2.2 Composição Química 85

4.2.3 Porosimetria por Injeção de Mercúrio 86

4.3 Ensaio na Célula de Difusão 89

4.3.1 Equipamento e Metodologia 89

4.3.2 Parâmetros de Transporte 92

4.3.3 Análise e Resultado 94

4.4 Considerações Finais 102

5 Análise de Estabilidade considerando a Interação Rocha-Fluido 104

$\begin{array}{lll}5.1 & \text { Introdução } & 104\end{array}$

5.2 Metodologia 104

5.3 Análise e Resultado 108

5.4 Considerações Finais 115 
6 Conclusão e Sugestão para Trabalhos Futuros

6.1 Conclusão

117

6.2 Sugestão para Trabalhos Futuros

118

7 Referências bibliográficas

120 


\section{Lista de Figuras}

Figura 2.1 - Típicas ocorrências de problemas de perfuração de poços (Duarte. 2004).

Figura 2.2 - Classificação de cascalhos de folhelho. A) cascalhos lascados; B) cascalhos desmoronados (Rocha \& Azevedo, 2007). 26

Figura 2.3 - Fechamento do poço (Oilfield Review, 1999). 28

Figura 2.4 - Relação Causa-Consequência dos Problemas de Perfuração (Tavares, 2006).

Figura 2.5 - Problemas de instabilidade normalmente observados durante a perfuração de camadas de folhelhos (Hawkes \& McLellan, 2000).

Figura 2.6 - Tipos de ruptura ao redor de poços (Modificada de Fjaer et al., 1992).

Figura 2.7 - Fluxograma da classificação dos fluidos à base água.

Figura 2.8 - Fluxo osmótico de água através de uma membrana semipermeável perfeita (Hawkes \& McLellan, 2000)

Figura 2.9 - Mecanismo de transporte de água através de uma membrana semi-permeável sob condições de campo (Hawkes \& McLellan, 2000).

Figura 2.10 - Mecanismo de impermeabilização promovido na interface óleo-fluido dos poros (Dussealt \& Gray, 1992).

Figura 3.1 - Boletim diário de perfuração (Tavares, 2006).

Figura 3.2 - Metodologia para classificação e análise dos boletins (Miura et al., 2003).

Figura 3.3 - Exemplo típico de um perfil Caliper. 54

Figura 3.4 - Módulo de Perfis (SEST, 2012). 55

Figura 3.5 - Método de Eaton para estimar a Pressão de Poros (Rocha \& Azevedo, 2007).

Figura 3.6 - Breakouts e fraturas naturais e induzidas no perfil de imagem (Argote, 2012).

Figura 3.7 - Distribuição da pressão de poros para fluido não penetrante (a) e para fluido penetrante (b) (SEST, 2012).

Figura 3.8 - Exemplo típico de uma janela operacional de um poço (Rocha \& Azevedo, 2007). 
Figura 3.9 - Gráfico de Perfuração versus Tempo do poço P-001 (Relatório Técnico Parcial 4, 2017 - Projeto de Pesquisa e Desenvolvimento "Soluções em Folhelhos").

Figura 3.10 - Correlação da litologia, Trajetória, Perfil Caliper e Gráfico de Profundidade versus Tempo do poço P-001 (Relatório Técnico Parcial 4, 2017 - Projeto de Pesquisa e Desenvolvimento "Soluções em Folhelhos").

Figura 3.11 - Estimativa do coeficiente de correlação através da regressão linear.

Figura 3.12 - Módulo de Perfis - Perfis de entrada do poço P-001 (Relatório Técnico Parcial 4, 2017 - Projeto de Pesquisa e Desenvolvimento "Soluções em Folhelhos").

Figura 3.13 - Módulo de Perfis - Perfis calculados pelo SEST (Relatório Técnico Parcial 4, 2017 - Projeto de Pesquisa e Desenvolvimento "Soluções em Folhelhos").

Figura 3.14 - Propriedades Mecânicas do poço P-001 (Relatório Técnico Parcial 4, 2017 - Projeto de Pesquisa e Desenvolvimento "Soluções em Folhelhos").

Figura 3.15 - Continuação das Propriedades Mecânicas do poço P001 (Relatório Técnico Parcial 4, 2017 - Projeto de Pesquisa e Desenvolvimento "Soluções em Folhelhos").

Figura 3.16 - Módulo de Gradientes - Janela Operacional do poço P001 (Relatório Técnico Parcial 4, 2017 - Projeto de Pesquisa e Desenvolvimento "Soluções em Folhelhos").

Figura 4.1 - Analisador de tamanho de partículas a laser da marca Cilas.

Figura 4.2 - Distribuição granulométrica do CP-A.

Figura 4.3 - Distribuição granulométrica do CP-B.

Figura 4.4 - Distribuição granulométrica do CP-C.

Figura 4.5 - Distribuição granulométrica do CP-D.

Figura 4.6 - Analisador de fluorescência de raio-x de energia dispersiva marca Shimadzu.

Figura 4.7 - Intrusão Acumulativa de mercúrio do CP-A, CP-B, CP-C e CP-D (Relatório Técnico, 2018 - Projeto de Pesquisa e Desenvolvimento "Soluções em Folhelhos").

Figura 4.8 - Intrusão incremental dos CP-A, CP-B, CP-C e CP-D (Relatório Técnico 2018 - Projeto de Pesquisa e Desenvolvimento "Soluções em Folhelhos").

Figura 4.9 - Células de difusão do Laboratório de Interação RochaFluido (LIRF).

Figura 4.10 - Ensaio para obter a atividade química da solução. 
Figura 4.11 - Corpo de prova na célula de difusão.

Figura 4.12 - Transmissão de pressão com água do CP-A (Relatório Técnico, 2018 - Projeto de Pesquisa e Desenvolvimento "Soluções em Folhelhos").

Figura 4.13 - Transmissão de pressão com água do CP-B e CP-C (Relatório Técnico, 2018 - Projeto de Pesquisa e Desenvolvimento "Soluções em Folhelhos").

Figura 4.14 - Transmissão de pressão com água do CP-D (Relatório Técnico, 2018 - Projeto de Pesquisa e Desenvolvimento "Soluções em Folhelhos").

Figura 4.15 - Fase da difusão de íons do CP-A submetida ao fluido 03 (Relatório Técnico, 2018 - Projeto de Pesquisa e Desenvolvimento "Soluções em Folhelhos").

Figura 4.16 - Fase da difusão de íons do CP-B submetida ao fluido 01 (Relatório Técnico, 2018 - Projeto de Pesquisa e Desenvolvimento "Soluções em Folhelhos").

Figura 4.17 - Fase da difusão de íons do CP- B submetida ao fluido 02 (Relatório Técnico, 2018 - Projeto de Pesquisa e Desenvolvimento "Soluções em Folhelhos").

Figura 4.18 - Fase da difusão de íons do CP-C submetida ao fluido 01 (Relatório Técnico, 2018 - Projeto de Pesquisa e Desenvolvimento "Soluções em Folhelhos").

Figura 4.19 - Fase da difusão de íons do CP-C submetida ao fluido 02 (Relatório Técnico, 2018 - Projeto de Pesquisa e Desenvolvimento "Soluções em Folhelhos").

Figura 4.20 - Fase da difusão de íons do CP-D submetida ao fluido 02 (Relatório Técnico, 2018 - Projeto de Pesquisa e Desenvolvimento "Soluções em Folhelhos").

Figura 5.1 - Malha utilizada para calcular a área plastificada ao redor do poço (Araújo, 2005). 


\section{Lista de Tabelas}

Tabela 2.1 - Problema de perfuração e principal agente causador (Modificada de Tavares, 2006).

Tabela 2.2 - Indicativos de ocorrência do problema (Modificada de Tavares, 2006).

Tabela 2.3 - Fatores associados à ocorrência de problemas geomecânicos (Modificada de Rabelo, 2008).

Tabela 3.1 - Dados do poço analisado.

Tabela 4.1 - Amostras de testemunho do poço P-001 e suas respectivas profundidades.

Tabela 4.2 - Composição química dos fluidos de solução salina em estudo.

Tabela 4.3 - Tabela comparativa dos resultados dos ensaios de granulometria.

Tabela 4.4 - Classificação das amostras quanto a distribuição de tamanho de grãos.

Tabela 4.5 - Análises químicas dos constituintes dos folhelhos.

Tabela 4.6 - Parâmetros obtidos do ensaio de porosimetria por injeção de mercúrio.

Tabela 4.7 - Valores da permeabilidade obtidos no ensaio de transmissão de pressão (Relatório Técnico, 2018 - Projeto de Pesquisa e Desenvolvimento "Soluções em Folhelhos").

Tabela 4.8 - Indicação dos ensaios realizados na fase de difusão de íons.

Tabela 4.9 - Valores dos parâmetros obtidos após os ensaios de difusão.

Tabela 4.10 - Resumo dos parâmetros obtidos nos ensaios de caracterização e difusão (Relatório Técnico, 2018 - Projeto de Pesquisa e Desenvolvimento "Soluções em Folhelhos").

Tabela 5.1 - Parâmetros necessário para cálculo pontual da janela operacional considerando efeitos de interação físico-química. 
Tabela 5.2 - Dados de entrada para análise de estabilidade na profundidade $5135 \mathrm{~m}$ do poço P-001.

Tabela 5.3 - Dados de entrada para análise de estabilidade na profundidade $5193 \mathrm{~m}$ do poço P-001.

Tabela 5.4 - Dados de entrada para análise de estabilidade na profundidade $5336 \mathrm{~m}$ do poço P-001.

Tabela 5.5 - Valores do colapso inferior em lb/gal correspondente ao tempo de exposição do folhelho ao fluido de perfuração e ao modelo elástico para fluido não penetrante e para fluido penetrante na profundidade de $5135 \mathrm{~m}$ (Relatório Técnico, 2018 - Projeto de Pesquisa e Desenvolvimento "Soluções em Folhelhos").

Tabela 5.6 - Valores do colapso inferior em lb/gal correspondente ao tempo de exposição do folhelho ao fluido de perfuração e ao modelo elástico para fluido não penetrante e para fluido penetrante na profundidade de 5193m (Relatório Técnico, 2018 - Projeto de Pesquisa e Desenvolvimento "Soluções em Folhelhos").

Tabela 5.7 - Valores do colapso inferior em lb/gal correspondente ao tempo de exposição do folhelho ao fluido de e ao modelo elástico para fluido não penetrante e para fluido penetrante na profundidade de 5336m (Relatório Técnico, 2018 - Projeto de Pesquisa e Desenvolvimento "Soluções em Folhelhos"). 


\section{Lista de Símbolos e Siglas}

\begin{tabular}{|c|c|}
\hline$\phi$ & Ângulo de atrito \\
\hline$a_{1}$ & Atividade química da água na região de menor concentração iônica \\
\hline$a_{2}$ & Atividade química da água na região de maior concentração iônica \\
\hline$A_{f}$ & Atividade química do fluido de perfuração ou da solução salina utilizada \\
\hline$A_{f h}$ & Atividade química do fluido dos poros do folhelho \\
\hline B & Parâmetro de pressão de poros de Skempton \\
\hline BDP & Boletim Diário de Perfuração \\
\hline c & Coesão \\
\hline C & Constante de conversão de unidades \\
\hline$C_{b}$ & Compressibilidade \\
\hline $\mathrm{CP}$ & Corpo de prova \\
\hline $\mathrm{D}$ & Coeficiente de difusão iônica \\
\hline D50 & Diâmetro de poros correspondente a $50 \%$ do volume total intrudido \\
\hline $\mathrm{dtc}$ & Tempo de trânsito da onda compressional \\
\hline dtcm & Tempo de trânsito da onda compressional da matriz \\
\hline dtms & Tempo de trânsito da onda cisalhante da matriz \\
\hline dts & Tempo de trânsito da onda cisalhante \\
\hline $\mathrm{E}$ & Módulo de Young \\
\hline ECD & Densidade equivalente de circulação \\
\hline G & Módulo de cisalhamento \\
\hline g & Aceleração da gravidade \\
\hline$G_{o v}$ & Gradiente de sobrecarga \\
\hline$G_{P}$ & Gradiente de pressão de poros \\
\hline$G_{S}$ & Gradiente de sobrecarga \\
\hline$G_{N}$ & Gradiente normal de pressão de poros na área \\
\hline $\mathrm{k}$ & Razão entre as tensões principais efetivas \\
\hline $\mathrm{K}$ & Permeabilidade \\
\hline$K_{b}$ & Módulo de deformação volumétrica \\
\hline$K_{S}$ & Compressibilidade dos grãos \\
\hline LOT & Teste para determinar pressão de absorção \\
\hline Ms & Massa molar do soluto \\
\hline
\end{tabular}




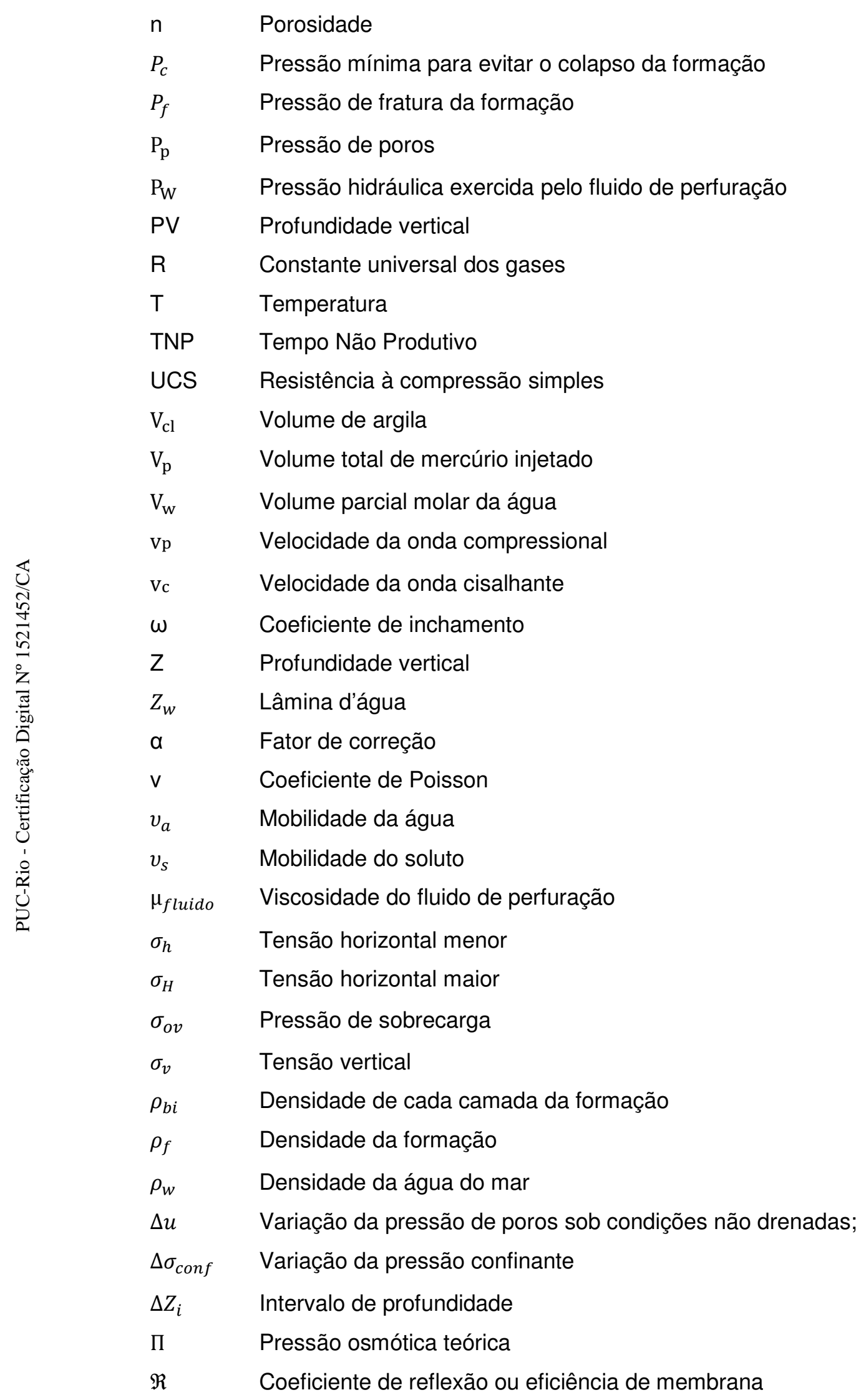




\section{1 \\ Introdução}

\section{1 \\ Motivação}

Os folhelhos são rochas sedimentares de granulação fina composta basicamente por minerais de argila. A baixa permeabilidade, a fissilidade e a facilidade de reagir quimicamente dos componentes da argila são características que conferem ao folhelho propriedades físico-químicas únicas, quando comparadas com outras rochas sedimentares. Tais características fazem com que sejam suscetíveis a diferentes fenômenos que causam instabilidade no processo de perfuração de poços de petróleo e gás.

Frequentemente, a indústria do petróleo vem enfrentando problemas de instabilidade de poços, sendo a instabilidade em formações de folhelhos o maior evento responsável pelo aumento dos gastos econômicos devido a geração de custo operacional extra durante o processo de perfuração e ao incremento de tempo não produtivo. Cerca de $75 \%$ das formações perfuradas em poços de petróleo são folhelhos e mais de $90 \%$ dos problemas de instabilidade das paredes do poço estão relacionados à inabilidade do fluido de perfuração em estabilizar esses folhelhos (Steiger \& Leung, 1992), o que o caracteriza como uma formação instável.

O processo de instabilidade de poços é o resultado de fenômenos físicoquímicos (Rabe et al., 2003) e mecânicos (Tan et al., 1997) que ocorrem durante e após a perfuração. Esta interação pode mudar a magnitude das tensões da formação ao redor do poço, gerar excesso de pressão de poros, hidratar os argilominerais e aumentar o teor de umidade da formação. As instabilidades mecânicas podem ser prevenidas e controladas mediante a otimização do peso do fluido de perfuração. Diferentes destas, as instabilidades físico-químicas são dificilmente controláveis e mais complexas, pois, além de possuírem diversas variáveis, dependem do tempo.

Os principais problemas de instabilidade associados aos folhelhos são: desmoronamento do poço, alargamento do poço, fechamento de poço, perda de circulação do fluido de perfuração, pack-off e elevados valores de torque e drag. 
A resolução destes problemas implica em tempo ocioso na perfuração e o consequente aumento de custos para a indústria do petróleo.

A fim de combater o problema de instabilidade dos folhelhos, fluidos de perfuração base óleo foram usados durante muito tempo pela indústria por apresentarem vantagens como a geração de alta pressão capilar no contato óleofolhelho que impede o ingresso de água e íons na formação. Porém, o uso destes fluidos foi restringido no mundo inteiro por legislações ambientais devido ao seu alto potencial de poluição e, também, pelo seu elevado custo. Estes foram substituídos por fluidos base água e, como consequência, os problemas de instabilidade passaram a ser mais frequentes.

Desta forma, a indústria do petróleo começou a demonstrar um grande interesse no desenvolvimento de fluidos de perfuração à base de água ambientalmente corretos e que promovam a estabilização da formação de maneira eficaz, ou seja, que previnam o incremento de pressão de poros na parede do poço. Pesquisas vêm sendo desenvolvidas a fim de analisar o comportamento dos folhelhos expostos aos fluidos de perfuração à base água contendo diversos componentes químicos como soluções salinas e aditivos com a finalidade de obter parâmetros a serem usados diretamente na mitigação dos problemas de instabilidade nos folhelhos.

Diante disso, uma boa análise das interações físico-químicas e o conhecimento das propriedades estruturais micro e macroscópicas dos folhelhos garantem a otimização do projeto do fluido de perfuração e a estabilidade do poço no processo de perfuração.

\section{2}

\section{Objetivo}

O objetivo geral desta dissertação é analisar e compreender os casos de instabilidade do poço através da análise de Dados de Perfuração (Dados de Perfis e Boletim Diário de Perfuração), de Amostras de Testemunhos e da Análise Computacional, com o intuito de criar uma metodologia que integre os resultados de campo e de laboratório e auxiliem na identificação de fluidos mais competentes que atuem na estabilidade físico-química em trechos de folhelho, reduzindo a dispersão de sólidos no fluido, inibindo a reatividade do folhelho e a invasão do fluido no interior do mesmo. A dissertação forma parte do escopo do projeto de Pesquisa e Desenvolvimento (P\&D) entre a PETROBRAS e a PUC-Rio intitulado "Soluções em folhelhos". 
Quatro amostras de folhelho de diferentes profundidades do Poço 001 foram estudadas e caracterizadas. Os corpos de prova destes folhelhos foram submetidos a diferentes soluções salinas aquosas nas células de difusão a fim de simular as condições de tensão in situ e a interação físico-química entre os fluidos de perfuração à base de água contendo eletrólitos (comumente utilizados na indústria como inibidor químico de formações argilosas) e os folhelhos.

Os parâmetros de transporte obtidos no ensaio, necessários para a análise de estabilidade de poço considerando os efeitos físico-químicos, foram: a eficiência de membrana ou coeficiente de reflexão $(\alpha)$ e a permeabilidade absoluta do folhelho.

A partir dos parâmetros obtidos experimentalmente e dos dados obtidos de perfis foi realizada a análise de estabilidade do poço em trechos pontuais de folhelho considerando os efeitos físico-químicos com apoio do software SEST Sistema de ESTabilidade, desenvolvido pela PUC-Rio em conjunto com a PETROBRAS.

\section{3 \\ Estrutura da dissertação}

O Capítulo 2 apresenta, primeiramente, uma revisão bibliográfica das principais ocorrências dos problemas de perfuração, bem como os indícios observados e a correlação destes com seus principais agentes causadores. Posteriormente, são descritas as causas da instabilidade do poço, sendo estas subdivididas em fatores mecânicos e físico-químicos. Com intuito de melhor compreender e mitigar os problemas de instabilidade dos poços em regiões de folhelhos, são descritas as características principais desta formação. Em seguida, é apresentada uma breve revisão dos fluidos de perfuração e sua classificação. Por fim, é descrito o processo de interação rocha-fluido, incluindo o mecanismo de transporte de massa, o efeito da permeabilidade e os efeitos desta interação na estabilidade do poço.

A metodologia proposta por esta dissertação é estruturada por três análises distintas. A primeira análise é descrita no Capítulo 3 cujo intuito é identificar os possíveis problemas de instabilidade de um poço através da retroanálise de estabilidade e, a partir disso, propor um novo tipo de fluido que proporcione um melhor desempenho para futuras operações em poços correlacionados. Inicialmente, apresenta-se a descrição dos dados disponíveis, isto é, BDP e perfis do poço. Em seguida, inclui-se a descrição do processo para a análise de 
estabilidade do poço com apoio do software SEST. Por último, são apresentados os resultados da análise de um estudo de caso utilizando a metodologia apresentada neste capítulo.

O Capítulo 4 descreve a segunda análise: a análise experimental dos quatro testemunhos do poço em estudo, com o objetivo de obter os parâmetros de transporte de massa da interação destas amostras quando submetidas a diferentes fluidos de solução salina, através de ensaios de difusão. Primeiramente, são apresentados os ensaios de caracterização dos folhelhos estudados. Incluemse também a metodologia e a descrição das fases de ensaios na célula de difusão e os procedimentos para obter os parâmetros de transporte. Por fim, são apresentadas as análises dos resultados e as considerações finais deste capítulo.

O Capítulo 5 descreve a terceira e última análise da dissertação, a análise de estabilidade considerando efeitos físico-químicos. A análise tem por intuito constatar como o folhelho se comporta aos fluidos hipotéticos sugeridos no Capítulo 4, visando esclarecer de que maneira as propriedades físico-químicas podem influenciar na estabilidade de poços, e se estes fluidos são mais eficientes do que o utilizado anteriormente. São descritos a metodologia, bem como os parâmetros adotados para gerar a análise. Por último, são apresentadas as análises dos resultados e as considerações finais deste capítulo.

No Capítulo 6, apresentam-se as conclusões gerais e sugestões para trabalhos futuros.

No Capítulo 7 são apresentadas as referências bibliográficas citadas nesta dissertação. 


\section{2 \\ Revisão bibliográfica}

Este capítulo apresenta, inicialmente, uma revisão dos conceitos e considerações dos problemas de perfuração de poços e a identificação dos problemas mediante a indícios constatados no BDP. Em seguida, são apresentadas as causas mecânicas e físico-químicas da instabilidade de poços em folhelhos. A definição da rocha folhelho e dos fluidos de perfuração utilizados na indústria são descritos na sequência. E por fim, a interação rocha-fluido, governada pelos mecanismos de transportes de massa.

\section{1 \\ Introdução}

Instabilidade de poços em folhelhos é a maior fonte de problemas de tempo e de custo durante a perfuração. Quando o poço é perfurado, o equilíbrio mecânico e físico-químico preexistente é perturbado, condicionando a estabilidade do poço à interação de fatores geomecânicos, geométricos e constitutivos que controlam o comportamento do poço.

A identificação de indícios dos problemas de perfuração de poços através de uma análise do Boletim Diário de Perfuração permite constatar os eventuais problemas do poço e seus principais agentes causadores e, consequentemente, auxiliar na mitigação das causas de instabilidade de poços em folhelhos.

Tais problemas são creditados, em geral, à interação entre o fluido de perfuração e o folhelho. Para um maior entendimento dos fenômenos de interação rocha-fluido, é necessário, primeiramente, que se tenha uma descrição completa da rocha e, posteriormente, a compreensão dos fenômenos de transporte e do comportamento do folhelho frente a estes fluidos.

\section{2}

\section{Problemas de Perfuração em Poços}

A operação de perfuração de poços de petróleo é bastante complexa e sujeita a ocorrência de uma série de anormalidades. Segundo Bol et al.,1994, os problemas geralmente se acumulam ao longo do tempo, começando com a 
fragmentação na parede do poço, seguido pela transferência de fragmentos para o anular e culminando em problemas (se a limpeza do poço é insuficiente) como obstrução do espaço anular e prisão de coluna de perfuração. As consequências podem incluir a ocorrência de cimentação pobre devido a washouts excessivos, a necessidade de desviar o poço ou até a perda do mesmo. A Figura 2.1 ilustra as típicas ocorrências de problemas de perfuração em poços.

Estas complicações que podem ocorrer durante a perfuração são altamente indesejáveis e causam prejuízos como contratação de tempo adicional de sonda, atraso no cronograma e aumentos de custos do projeto. Desde então, estudos têm sido conduzidos a fim de um maior entendimento das causas dos problemas e dos possíveis meios de evitá-los.

Em vista disso, a seguir é apresentada uma breve descrição de alguns problemas de perfuração que podem ser identificados no Boletim Diário de Perfuração (BDP) e que podem estar relacionados à instabilidade de poços durante a perfuração em trechos de folhelhos.

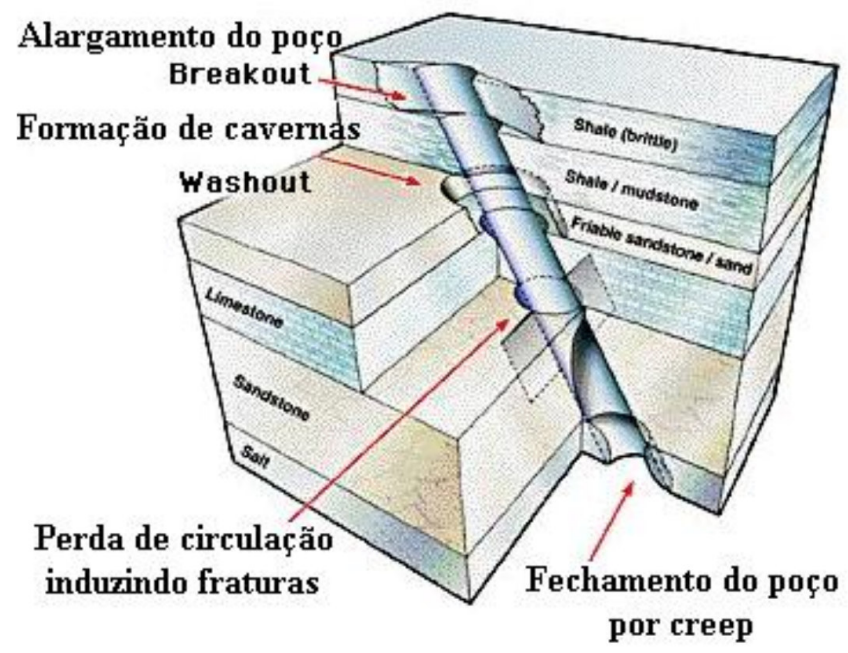

Figura 2.1 - Típicas ocorrências de problemas de perfuração de poços (Duarte. 2004).

\subsubsection{Perda de Circulação}

Tavares (2006) define a perda de circulação como a perda total ou parcial de fluido de perfuração para formação. O fluxo do poço para a formação pode ocorrer em formações naturalmente fraturadas ou de alta permeabilidade - onde a pressão exercida na parede do poço é maior que a pressão de poros da formação nesses horizontes - ou até mesmo ser capaz de fraturar a formação quando a pressão exercida na parede do poço é maior que a pressão de fratura da formação. 
A perda total de circulação pode causar desmoronamento do poço se o nível de fluido de perfuração dentro do mesmo não for rapidamente restaurado. Isso ocorre porque as formações mais rasas ficam sem o suporte proporcionado pela pressão hidrostática do fluido de perfuração. O desmoronamento provoca 0 alargamento do poço e, consequentemente, o acúmulo de cascalhos no espaço anular.

Segundo Tavares, dois fatores chaves na prevenção da perda de circulação são:

1. O acompanhamento do peso de fluido: A pressão hidrostática dentro do poço deve ser a menor possível, mas grande o suficiente a fim de conter kicks. Além disso, o fluido deve conter sólidos de granulometria adequada com a finalidade de bloquear os poros da formação.

2. Posicionamento da sapata: um incorreto posicionamento da sapata pode fraturar a formação logo abaixo da mesma devido à alta pressão hidrostática requerida para perfurar a próxima fase do poço.

\subsubsection{Kick}

O kick é o influxo indesejado de fluidos presentes na formação (água, gás ou óleo) para dentro do poço, devido à existência de uma pressão hidrostática no interior do mesmo insuficiente para conter a pressão da formação. Quando o mesmo ocorre de maneira descontrolada e atinge a superfície chama-se blowout.

Kicks podem provocar instabilidades no poço tais como desmoronamentos, alargamentos, fechamento do poço, contaminação do fluido de perfuração, entre outros.

\subsubsection{Desmoronamento do Poço}

O desmoronamento do poço é caracterizado pela queda de fragmentos ou blocos de rocha que formam parte da parede do poço. Pode ser provocado pela pressão hidrostática insuficiente do fluido de perfuração no interior do poço que não suporta a pressão de poros da formação, pela ação mecânica da coluna de perfuração sobre as paredes do poço ou por ruptura à compressão normalmente caracterizada por rupturas diametralmente opostas.

A identificação das causas de desmoronamento pode ser feita através da análise das características dos cascalhos provenientes do poço tais como formato, 
tamanho e aumento de retorno. Segundo Rocha \& Azevedo (2007), os cascalhos lascados e desmoronados dos folhelhos se ajustam bem a esse tipo de análise, pois podem dar uma boa indicação das condições de estabilidade das paredes do poço e da formação.

O folhelho lascado possui formato côncavo e se apresenta em forma de lascas, sendo geralmente mais pontiagudo e fino, já o folhelho desmoronado é mais espesso e retangular, conforme Figura 2.2. Indica-se que os cascalhos em forma de lasca geralmente são resultados de falhas por tração e muitas vezes associados a pressões anormalmente altas ou ao sub-balanceio do poço, isto é, quando o peso do fluido de perfuração se encontra inferior à pressão de poros. $O$ cascalho desmoronado, embora também esteja relacionado ao peso de fluido insuficiente, não é resultante de zonas com pressões anormalmente altas.

Outras maneiras de identificação de desmoronamento incluem a elevação na pressão de bombeio, devido ao aumento de carga de cascalho no anular do poço e o aumento do esforço para retirar a coluna do poço, devido ao aumento da fricção.

Para conter o desmoronamento, o aumento da densidade do fluido de perfuração é necessário.

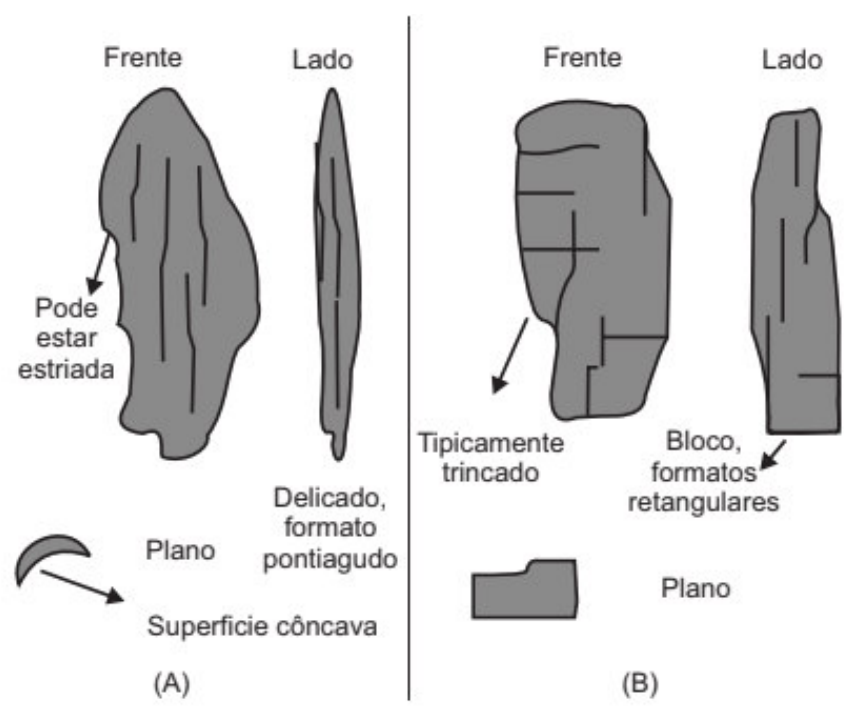

Figura 2.2 - Classificação de cascalhos de folhelho. A) cascalhos lascados; B) cascalhos desmoronados (Rocha \& Azevedo, 2007).

\subsubsection{Alargamento do Poço}

O alargamento do poço é caracterizado por um aumento não desejado do diâmetro do poço. Pode ser provocado por desmoronamentos localizados, por influxos de fluidos para dentro do poço, pela erosão da formação provocada por 
regime de fluxo turbulento ou até mesmo por atrito mecânico da coluna de perfuração com as paredes do poço (Tavares, 2006).

O alargamento do poço prejudica a qualidade da cimentação, provoca "topadas" na descida do revestimento e dificulta operações de pescaria.

Para conter o alargamento, o peso de fluido deve ser alto o suficiente para dar sustentação mecânica para as paredes do poço, mas não demasiadamente elevado, para não induzir a ocorrência de fraturas na formação ao redor do poço.

\subsubsection{Má Limpeza do Poço}

Durante a perfuração de um poço, os cascalhos gerados pela broca são removidos para a superfície através da circulação do fluido no poço. A má limpeza do poço ocorre quando os cascalhos não são devidamente removidos do poço e acabam se acumulando no espaço anular.

O acúmulo de cascalhos no poço pode ocorrer devido a uma vazão insuficiente de circulação do fluido, devido ao uso de um fluido inadequado para o carreamento de cascalho, ou ainda devido a problemas de desmoronamento e alargamento do poço e pode ser detectado pelo aumento de pressão de bombeio e pela dificuldade de retirar a coluna do poço.

Segundo Yarim et. al. (2010), a má limpeza é um problema comum e custoso na perfuração de poços direcionais e horizontais, pois podem causar desgastes da broca, baixas taxas de perfuração, elevados valores de torque e drag, e até mesmo a prisão da coluna de perfuração. Se a situação não for tratada da maneira correta, podem ocorrer desvios na trajetória ou até mesmo a perda do poço (Argote, 2012).

\subsubsection{Packer Hidráulico (Pack-off)}

O Packer Hidráulico ocorre quando o espaço anular entre a coluna de perfuração e o poço é obstruído, normalmente, por acúmulos de detritos no espaço anular. Este acúmulo de cascalhos pode ser provocado pela má limpeza do poço, desmoronamento ou devido ao inchamento da formação por hidratação.

Pode ser constatado através de um súbito aumento na pressão de bombeio, podendo ocorrer perda de circulação devido ao excessivo aumento de pressão no fundo do poço. 


\subsubsection{Fechamento do Poço}

O fechamento consiste na redução da seção transversal do poço provocada pela ruptura por compressão de acordo com o comportamento dúctil ou frágil das rochas perfuradas (Figura 2.3). Pode ocorrer devido à hidratação do folhelho, à fluência do sal, ao desgaste da broca em formações abrasivas e ao espessamento do reboco.

1. Fechamento do poço devido à hidratação dos folhelhos: é uma obstrução total ou parcial, havendo um estreitamento no diâmetro do poço, devido ao inchamento dos minerais de argila por hidratação, em função da utilização de fluido de perfuração base água pouco inibido.

2. Fechamento do poço devido à fluência do sal: durante a perfuração de formações salinas onde o peso de fluido é insuficiente para manter as paredes do poço, é comum a ocorrência da diminuição de seu diâmetro.

3. Fechamento do poço devido ao desgaste da broca em formações abrasivas: ocorre durante a perfuração de rochas abrasivas, como o arenito, em que a broca sofre desgaste e, com isso, o poço perde seu calibre e tende a reduzir gradualmente seu diâmetro.

4. Fechamento do poço por espessamento do reboco: ocorre durante a perfuração de formações permeáveis em que os sólidos contidos no fluido de perfuração formam um reboco de tal maneira que acaba reduzindo o diâmetro do poço.
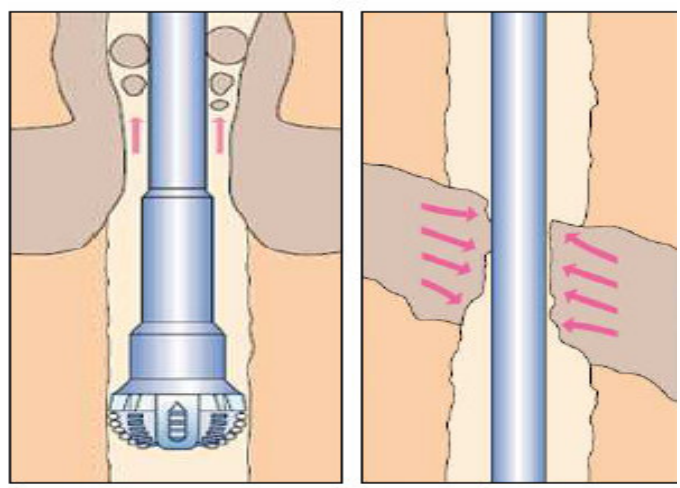

Figura 2.3 - Fechamento do poço (Oilfield Review, 1999). 


\subsubsection{Torque e Drag Elevados}

O torque é definido como o momento necessário para girar a coluna. Já o drag é caracterizado como o esforço adicional para movimentação axial da coluna devido a forças de atrito.

Obtêm-se boas estimativas de torque e drag, multiplicando-se o fator de atrito pela força normal da coluna sobre as paredes do poço, os quais podem ser usados para diagnosticar problemas no poço quando combinados com outros parâmetros, tais como: variação da pressão de bombeio, pistoneios, amostras de calha, repassamentos, entre outros (Argote, 2012).

Segundo Idagawa (1990), a avaliação destes parâmetros é importante, pois permite o conhecimento das condições mecânicas das paredes do poço, fazendo com que seja possível identificar a tempo problemas como prisão de coluna ou do cabo de perfilagem através do aumento de torque e drag.

O monitoramento combinado de torque, drag e da densidade equivalente de circulação fornecem informações adicionais sobre as condições da limpeza do poço. A técnica também permite otimizar a programação dos repasses para que eles sejam feitos corretamente somente quando são necessários (Vos, 2000).

\subsubsection{Repasse}

Repasse é uma operação feita a fim de manter em boas condições as paredes dos poços para que os revestimentos, perfis elétricos, colunas de pescaria e demais componentes da coluna de perfuração possam descer sem encontrar restrições nos diâmetros planejados do projeto do poço.

As operações de repasse são geralmente necessárias na retirada da coluna de perfuração quando houver indícios de resistência (por exemplo, acunhamento), na descida da coluna de perfuração quando há intervalos que ofereçam resistência (topamento) e quando há ameaça de prisão de coluna.

Se não forem feitos de maneira cautelosa, os repasses podem causar problemas ao invés de resolvê-los, comprometendo o funcionamento do poço pela geração de desmoronamento e, consequentemente, de uma grande quantidade de cascalhos que podem chegar a causar problemas de estabilidade e prisões na coluna de perfuração.

Segundo Yarim et al. (2010), as operações de repasse em formações instáveis, que são sensíveis à agitação mecânica, tais como folhelhos fraturados, podem ter um efeito negativo para a integridade do poço, devido à transmissão de 
vibrações por parte da coluna de perfuração ao folhelho fraturado, causando alargamento no diâmetro do poço e a necessidade de carrear mais sólidos.

\section{3}

\section{Identificação de Problemas do Poço}

A partir das descrições dos problemas de perfuração na seção anterior, constata-se que, em alguns casos, estes possuem uma relação de causa e consequência entre si.

Tavares (2006) apresenta algumas das relações de causa e consequência por meio da Figura 2.4 .

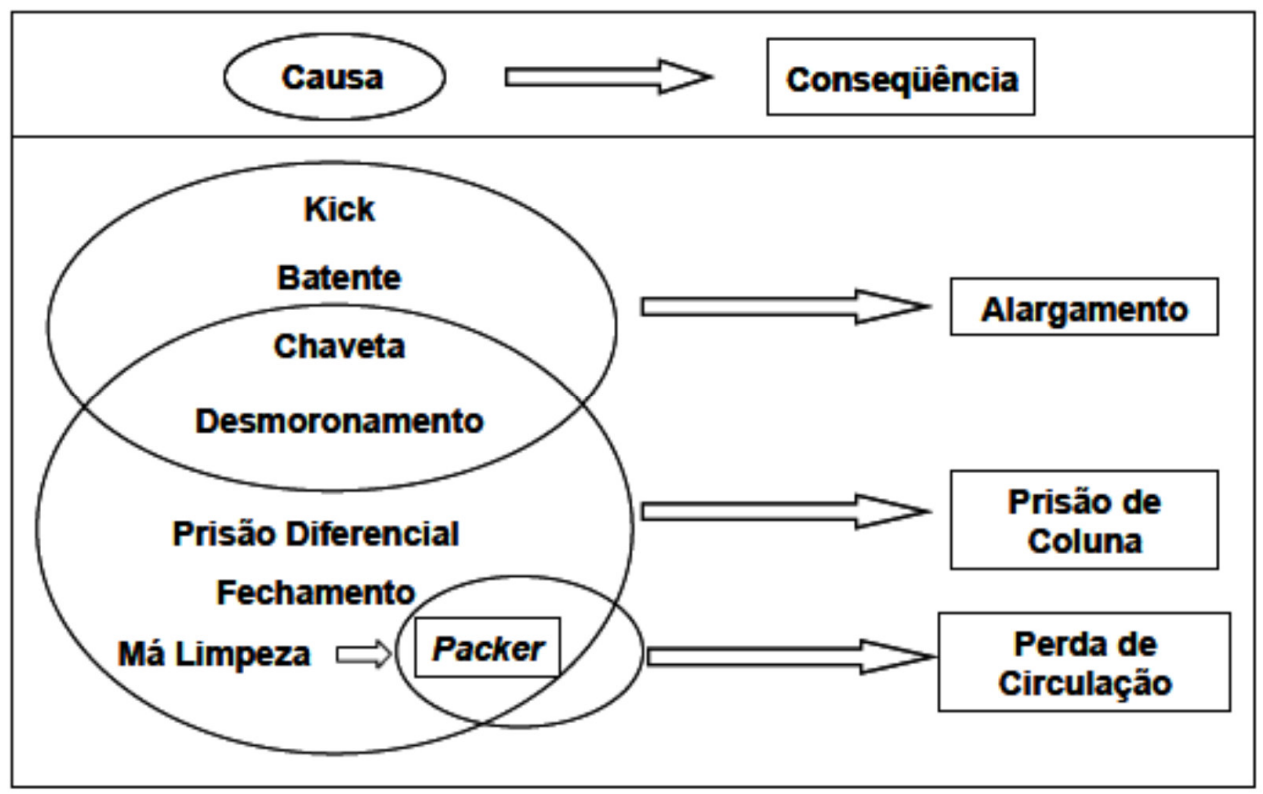

Figura 2.4 - Relação Causa-Consequência dos Problemas de Perfuração (Tavares, 2006).

O autor mapeou um principal agente causador para maioria dos problemas de perfuração considerando o mecanismo responsável pela ocorrência em cada caso e concluiu a existência de quatro principais agentes causadores: Fluido de Perfuração, Geometria do Poço, Características da Formação e Parâmetros Mecânicos. Contudo na Tabela 2.1 são listados apenas os dois principais agentes causadores correlacionados aos problemas anteriormente descritos nesta dissertação.

De acordo com a classificação apresentada na Tabela 2.1, o autor constata que o fluido de perfuração está relacionado a diversos problemas de perfuração. Agrupando a classe de problemas motivados por aspectos relativos ao fluido, o autor conclui que é possível evoluir na análise e apontar quais seriam os indícios da ocorrência de cada problema. 
Tabela 2.1 - Problema de perfuração e principal agente causador (Modificada de Tavares, 2006).

\begin{tabular}{|c|c|c|}
\hline Problema & Principal Agente Causador & Parâmetro \\
\hline Perda de circulação & Fluido de perfuração & ECD > Pf \\
\hline $\begin{array}{c}\text { Desmoronamento/ } \\
\text { Alargamento de Poço }\end{array}$ & Fluido de perfuração & ECD<Pc \\
\hline $\begin{array}{c}\text { Má Limpeza do Poço / } \\
\text { Pack Off }\end{array}$ & Fluido de perfuração & Baixa mfluido e/ou Baixa V fluido \\
\hline Kick & Fluido de perfuração & ECD < Pp \\
\hline Fechamento do poço & Característica da formação & $\begin{array}{c}\text { Hidratação de argila / } \\
\text { Movimento de sal }\end{array}$ \\
\hline
\end{tabular}

Onde,

$P_{f}:$ pressão de fratura da formação;

$P_{p}:$ pressão de poros da formação

$P_{c}$ : pressão mínima para evitar o colapso da formação

$\mu_{\text {fluido }}$ : viscosidade do fluido de perfuração

$\mathrm{V}_{\text {fluido }}$ : velocidade de carreamento do fluido de perfuração

Tabela 2.2 - Indicativos de ocorrência do problema (Modificada de Tavares, 2006).

\begin{tabular}{|c|c|c|}
\hline Problema & Fluido de Perfuração & Indícios \\
\hline Perda de Circulação & Peso excessivo de fluido & $\begin{array}{c}\text { Reduzida vazão de retorno } \\
\text { Perda de volume nos tanques }\end{array}$ \\
\hline $\begin{array}{c}\text { Desmoronamento/ } \\
\text { Alargamento de Poço }\end{array}$ & Peso insuficiente de fluido & $\begin{array}{c}\text { Aumento no retorno de cascalhos } \\
\text { Cascalhos maiores e irregulares } \\
\text { Aumento do drag } \\
\text { Aumento do torque }\end{array}$ \\
\hline Má Limpeza do Poço / & Propriedades inadequadas & $\begin{array}{c}\text { Aumento da pressão de bombeio } \\
\text { Aumento do drag } \\
\text { Aumento do torque }\end{array}$ \\
\hline Kick Off & Peso insuficiente de fluido & $\begin{array}{c}\text { Aumento da vazão de retorno } \\
\text { Ganho de volume nos tanques }\end{array}$ \\
\hline
\end{tabular}

A Tabela 2.2 permite identificar de maneira antecipada o problema de perfuração através da observação dos indícios presentes nos parâmetros de superfície. Desse modo, os indícios seriam utilizados como sintomas que estariam anunciando a iminência da ocorrência de um problema (Tavares, 2006).

Rabelo (2008), assim como Tavares (2006), apresenta a Tabela 2.3 que correlaciona os problemas de perfuração às causas e aos indícios dos problemas 
observados. Para o autor, a maioria dos problemas de perfuração estão associados a causas de natureza geomecânica.

Tabela 2.3 - Fatores associados à ocorrência de problemas geomecânicos (Modificada de Rabelo, 2008).

\begin{tabular}{|c|c|c|}
\hline Problema & Causa & Indícios \\
\hline Alargamento & $\begin{array}{c}\text { Pressão hidráulica excessiva (vazão de bombeio) } \\
\text { Ação mecânica da coluna (BHA) } \\
\text { Reatividade da formação x fluido (tipo de fluido) } \\
\text { Desmoronamentos (regime de tensões) }\end{array}$ & $\begin{array}{l}\text { Topadas durante } \\
\text { manobras } \\
\text { Maior volume de } \\
\text { retorno de cascalho }\end{array}$ \\
\hline Desmoronamento & $\begin{array}{c}\text { Pressão hidrostática insuficiente } \\
\text { Ação mecânica da coluna (BHA) } \\
\text { Pressão hidráulica excessiva (vazão de bombeio) } \\
\text { Dissolução de domos salinos (litologia) }\end{array}$ & $\begin{array}{c}\text { Maior volume de } \\
\text { retorno de cascalhos } \\
\text { Drags elevados na } \\
\text { manobra } \\
\text { Cascalhos com } \\
\text { tamanho maior que o } \\
\text { normal }\end{array}$ \\
\hline Fechamento & $\begin{array}{l}\text { Reatividade da formação x fluido (tipo de fluido) } \\
\text { Formações com mobilidade (ex: sais) } \\
\text { Pressão hidrostática insuficiente (peso de fluido) }\end{array}$ & $\begin{array}{c}\text { Drags elevados na } \\
\text { manobra } \\
\text { Dificuldade na descida } \\
\text { do revestimento } \\
\text { Ameaças de prisão } \\
\end{array}$ \\
\hline Kick & $\begin{array}{c}\text { Pressão hidrostática insuficiente } \\
\text { Pistoneio (operação) } \\
\text { Perda de circulação (característica da formação/peso de } \\
\text { fluido) }\end{array}$ & $\begin{array}{l}\text { Aumento do volume de } \\
\text { lama nos tanques } \\
\text { Aumento da vazão de } \\
\text { retorno } \\
\text { Fluxo com bombas } \\
\text { desligadas } \\
\end{array}$ \\
\hline $\begin{array}{c}\text { Perda } \\
\text { de Circulação }\end{array}$ & $\begin{array}{l}\text { Existência de fraturas na formação (característica da } \\
\text { formação) } \\
\text { Formações com alta permeabilidade e porosidade } \\
\text { (característica da formação) } \\
\text { Peso de fluido excessivo em zonas depletadas ou com } \\
\text { baixo gradiente de fratura }\end{array}$ & $\begin{array}{l}\text { Redução do volume de } \\
\text { lama nos tanques }\end{array}$ \\
\hline
\end{tabular}

\section{4}

\section{Causas de Instabilidade em Folhelhos}

Ao perfurar um poço, o estado de tensões nas formações rochosas atravessadas pela broca é alterado. O material removido pela escavação é substituído pelo fluido de perfuração, que entre outras funções, tenta restabelecer o equilíbrio anterior à escavação. O controle das tensões efetivas ao redor do poço ao longo do tempo é um fator importante, porém muito complexo, para mantê-lo estável. A indústria se baseia em parâmetros operacionais a fim de manter o mesmo objetivo, tais como: a densidade e composição do fluido de perfuração e o controle das variações da pressão do fluido no espaço anular. Contudo, isto nem sempre é atingido, e como consequência ocorre a geração de ruptura ao redor do poço.

A instabilidade de poços é um dos problemas frequentes que a indústria do petróleo tem enfrentado ao longo de décadas, sendo a instabilidade em folhelhos 
o maior item responsável pelo incremento de tempo não produtivo (TNP) e dos custos operacionais extras durante a perfuração. A mais importante variável para manter a estabilidade do poço em folhelhos seria prevenir a invasão de pressões elevadas dentro da matriz da formação (Stowe et al., 2001, Van Oort et al., 1994, Van Oort, 1997, Tare \& Mody, 2000).

Os problemas de instabilidade em folhelhos podem ser do tipo intrínseco como os relacionados com a interação físico-química do folhelho com o fluido de perfuração, à ruptura da rocha, ou do tipo operacional. Alguns destes problemas são mostrados na Figura 2.5.

Segundo Bol et al. (1994), a instabilidade em folhelhos é um fenômeno complexo e pode ser dividido em cinco áreas básicas do problema:

1- Perfuração em uma região naturalmente fraturada;

2- Perfuração através de um folhelho frágil;

3- Ruptura por tração;

4- Ruptura por compressão;

5- Ruptura por tensão de hidratação;

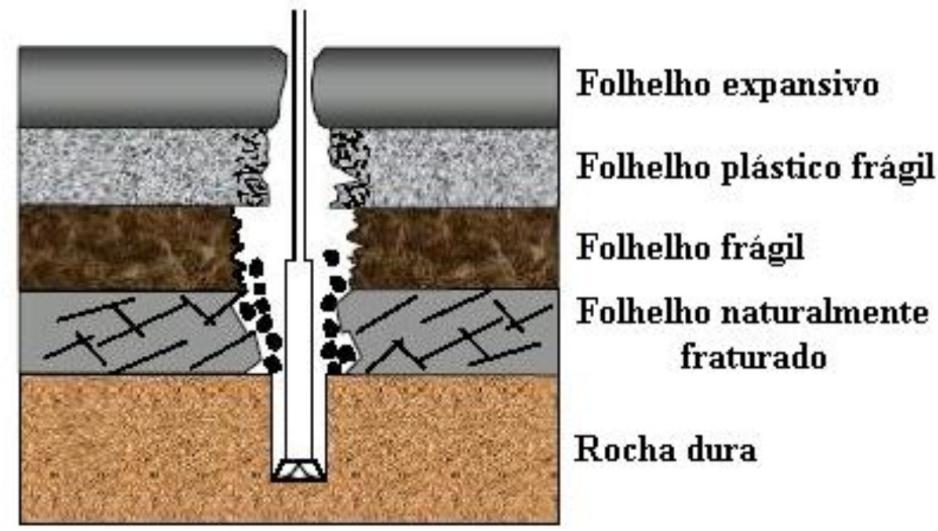

Figura 2.5 - Problemas de instabilidade normalmente observados durante a perfuração de camadas de folhelhos (Hawkes \& McLellan, 2000).

No primeiro caso, o dano já está feito, e somente a estabilização pós-falha e a limpeza otimizada do poço podem ajudar a aliviar o problema.

No segundo caso, a indução de fragmentação através de vibrações da coluna ocasiona problemas como alargamentos e até mesmo prisão de coluna. A redução das vibrações da broca de perfuração pode oferecer alívio adicional.

Os demais casos são classificados por diversos autores com base nos diferentes efeitos sobre a alteração da pressão dos poros e das tensões que atuam no folhelho, em fatores mecânicos e físico-químicos, os quais serão descritos a seguir. 


\subsubsection{Fatores Mecânicos}

Os fatores mecânicos são processos físicos que ocorrem quando as tensões mecânicas impostas na formação excedem a resistência do folhelho e geram rupturas de compressão ou de tração:

I. Ruptura por compressão: Também chamada de colapso, a ruptura ocorre quando a pressão hidrostática insuficiente do fluido de perfuração no interior do poço não suporta a pressão de poros da formação. A ruptura por compressão pode causar redução no tamanho do poço devido ao fluxo plástico ou, também, o alargamento de um eixo diametral da seção transversal do poço em uma rocha frágil, devido à formação de lascas, conforme Figura 2.6a.

II. Ruptura por tração (Figura 2.6b): Também chamada fraturamento, a ruptura ocorre, geralmente, quando o peso excessivo do fluido de perfuração ultrapassa a resistência à tração da rocha. Neste caso, podem ocorrer perdas de circulação de fluido para formação através das fraturas, ocasionando diminuição da pressão hidrostática nas formações superiores e inferiores e consequente risco de instabilidade do poço. A invasão do fluido de perfuração incrementa a pressão de poros da parede do poço, sendo transmitida para a formação conforme o passar do tempo. Além da alta densidade do fluido de perfuração, outras causas podem induzir fraturas durante a perfuração como a técnica inadequada de perfuração com altas velocidades de rotação, diferença pequena entre o diâmetro do poço e o diâmetro externo da coluna de perfuração podendo induzir pressões que superam a resistência à tração da formação.

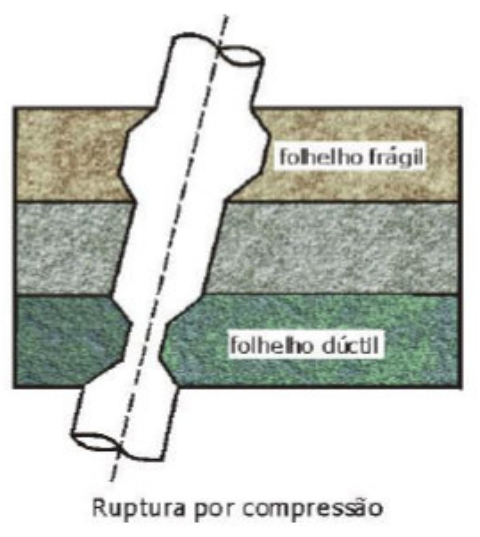

(a) Seção vertical

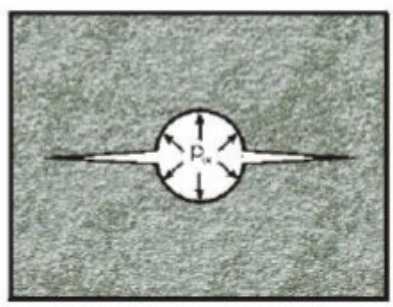

Ruptura por tração

(b) Vista do topo

Figura 2.6 - Tipos de ruptura ao redor de poços (Modificada de Fjaer et al., 1992). 


\subsubsection{Fatores Físico-Químicos}

A ruptura por tensão de hidratação ocorre devido às interações físicoquímicas da rocha com o fluido de perfuração ao longo do tempo.

A invasão do fluido de perfuração por gradiente hidráulico e/ou a difusão dos íons devido ao gradiente químico alteram a composição do fluido nos poros do folhelho resultando numa variação da pressão de hidratação e pressão de poros ao redor do poço. Como consequência, a tensão efetiva pode ser fortemente reduzida e gerar altas tensões radiais na formação que provocam ruptura por compressão ou por tração.

\section{5}

\section{Folhelho e Suas Características}

Os folhelhos têm um papel importante na exploração e produção de petróleo, pois são rochas formadoras de hidrocarbonetos e capeadoras das rochas reservatório (Horsrud et al., 1994).

Os folhelhos são rochas sedimentares, de granulação fina composta basicamente de minerais de argila com alta porosidade e baixa permeabilidade. Possuem anisotropia devido às condições de deposição dos sedimentos e à natural foliação das argilas, em outras palavras à fissilidade que estas possuem. Os folhelhos apresentam elevado potencial de reatividade frente aos fluidos de perfuração base água, o que Ihes concede propriedades físico-químicas únicas, quando comparadas com outras rochas sedimentares. Estas características transformam os folhelhos em uma rocha altamente sensível à instabilidade com o transcurso do tempo (Tan et al., 1998).

A composição dos folhelhos pode variar de acordo com a pré-disposição da rocha fonte. Segundo Suguio (1998), os folhelhos normalmente derivam de dois tipos de ambientes: marinhos (ricos em clorita e argilas do grupo ilita) ou lacustres (enriquecidos com esmectita). Geralmente, os folhelhos são compostos por quartzo, feldspato, calcita, e frações de argila em proporções variáveis, onde argilas susceptíveis a água, tais como a esmectita e ilita, podem constituir até $80 \%$ do peso total do folhelho (O’Brien \& Chenevert, 1973), desencadeando mecanismos de hidratação e dispersão, que podem causar problemas de instabilidade no poço com o passar do tempo.

A capacidade de certo folhelho adsorver água é função dos tipos de e quantidades de argilominerais que o compõe. Para um maior entendimento dos fenômenos de interação entre rocha e o fluido de perfuração é necessário, 
primeiramente, que se tenha uma descrição completa destas formações, tanto do ponto de vista de seus constituintes individuais quanto da sua microestrutura.

\subsubsection{Tipos de Argilominerais}

Segundo Amanullah et al. (2014), existem cinco principais grupos de argilas: caulinita, esmectita, ilita, vermiculita e clorita, sendo os três primeiros os grupos mais relevantes para atividades de perfuração.

A estrutura de argila consiste em camadas contendo planos de átomos. Estas camadas podem ser tetraédricas ou octaédricas. No caso da caulinita, a estrutura é disposta de modo que uma camada tetraédrica é seguida por uma camada octaédrica na proporção de 1: 1. Para outros tipos de argilas, cada camada octaédrica é intercalada entre duas camadas tetraédricas na proporção de 2: 1 (Brindley e Brown, 1980).

A variação na estrutura da argila pode ser um dos fatores que regem a resposta de cada tipo de argila ao processo de hidratação quando exposta à água. Cada amostra de folhelho tem alguma porcentagem de um ou mais tipos de argila, além de quartzo e outros minerais. Portanto, a mineralogia da amostra de folhelho determina sua resposta quando entra em contato com a água. Sone e Zoback (2013) realizaram vários experimentos mecânicos em vários tipos de folhelhos com diferente teor de argila e mineralogia. O objetivo era compreender os fatores que afetam as propriedades elásticas dos folhelhos. Foi realizada uma série de testes de resistência à compressão hidrostática e triaxial. Embora o coeficiente de Poisson não tenha sido encontrado em correlação com o conteúdo de argila, o módulo de Young mostrou uma forte correlação. Houve uma tendência geral para o módulo de Young diminuir à medida que o teor de argila aumenta. Baseado nesses resultados e em outras tendências também, eles concluíram que a ductilidade e a fragilidade dos folhelhos dependem da composição da amostra e da anisotropia. À medida que o teor de argila aumenta, a rocha do folhelho tende a se comportar no modo dúctil.

\subsubsection{Permeabilidade}

Folhelhos têm permeabilidades variando de $10^{-6}$ a $10^{-12}$ Darcy. Segundo Lal (1999), a baixa permeabilidade do folhelho é devido à pobre conectividade entre seus poros estreitos com diâmetros típicos entre 3nm a 10nm. 
A permeabilidade dos folhelhos é influenciada por vários fatores, entre eles podemos citar a distribuição de tamanho dos poros, a conectividade destes, a tortuosidade dos canais de fluxo, a porosidade, o tamanho e o arranjo dos seus grãos.

A característica comum nos folhelhos é sua anisotropia, a origem está ligada às condições de deposição dos sedimentos e à natural foliação das argilas; em outras palavras à fissilidade que estas possuem. A avaliação da anisotropia da permeabilidade é de grande importância quando se estuda fluxos de água ou íons dentro de formações rochosas.

Schlemmer et al. (2003), em ensaios que visavam estimar a permeabilidade do folhelho Pierre1E, reportaram valores na faixa de 0,3 a $10 \mu \mathrm{D}$ quando ensaiados paralelos ao plano de acamamento (ensaio horizontal). Por outro lado, a faixa de permeabilidade quando ensaiados perpendicularmente ao acamamento (ensaio vertical) foi entre 0,01 a $0,05 \mu \mathrm{D}$. Claramente, pode ser observado que as permeabilidades paralelas aos planos de acamamento são elevadas em relação às perpendiculares (anisotropia de 20 a 30). Se estas variações não são levadas em conta, podem ser fontes de erro de interpretação nos coeficientes de reflexão obtidos para um mesmo tipo de folhelho.

\subsubsection{Inchamento e Dispersão}

Amanullah et al. (2014) descreve o inchamento como a expansão das partículas de argila devido à hidratação da água. Os íons carregados negativamente são concentrados nas superfícies do folhelho enquanto que os carregados positivamente estão concentrados nas bordas. Devido à elevada concentração de cargas negativas, haverá troca de cátions onde os íons carregados positivamente são adsorvidos nas superfícies.

$\mathrm{Na}$ literatura, descrevem-se diferentes mecanismos de inchamento de folhelhos, incluindo inchamento cristalino e inchamento osmótico. A estrutura de esmectita é composta por duas camadas tetraédricas e uma camada octaédrica entre elas. Uma vez que a argila é carregada negativamente, são necessários cátions intercalares para neutralizá-la. Haverá reação de permuta catiônica que resultará num aumento da distância de espaçamento entre as camadas que, por sua vez, resultará na expansão da argila, isto é, no inchamento cristalino (Zhou e Law, 1998).

O inchaço osmótico ocorre devido à diferença na salinidade do fluido do folhelho e do fluido de perfuração. Para fluidos de perfuração de baixa salinidade, 
a água tende a se mover e difundir para o folhelho de maior salinidade e, assim, hidratar as partículas de folhelho. A absorção de água também cria uma camada dupla com potencial repulsivo levando à expansão da matriz de argila.

A dispersão é a desintegração progressiva dos folhelhos reativos na presença de água ou de uma lama não inibidora. Os folhelhos que possuem a caulinita como principal componente de argila têm geralmente uma elevada tendência de dispersão num ambiente de fluido reativo. Como resultado, problemas de desintegração de folhelhos serão encontrados e a eficiência da limpeza do poço será, significativamente, reduzida (Amanullah et al., 2014).

\section{6 \\ Fluido de Perfuração}

Grande parte dos problemas de instabilidade em poços de petróleo podem ser atribuídos ao tipo de fluido de perfuração. Portanto a escolha do fluido ideal é de grande importância para redução de custos e tempo.

Durante a perfuração, adota-se o fluido de perfuração, cuja composição química induz a comportamentos físico-químicos desejados, para permitir um equilíbrio entre as pressões das formações e a pressão dentro dos poços. O fluido de perfuração deve possuir propriedades físico-químicas que possam ser cuidadosamente controladas, para se ajustarem a uma grande variedade de condições em sub-superfície (Darley et al., 1988).

Thomas (2001) define os fluidos de perfuração como misturas complexas de sólidos, líquidos, e, por vezes, até de gases. De uma maneira geral, os fluidos de perfuração são sistemas multifásicos, que podem conter água, material orgânico, sais dissolvidos e sólidos em suspensão nas mais diversas proporções. Do ponto de vista físico, eles podem assumir aspectos de suspensão, dispersão coloidal ou emulsão, dependendo do estado químico dos componentes. Devem ser especificados de forma a garantir uma perfuração rápida e segura.

Os fluidos de perfuração são indispensáveis durante as atividades de perfuração de um poço, pois desempenham uma série de funções essenciais, destacando-se:

- Limpar o fundo do poço e carrear os cascalhos gerados durante a perfuração até a superfície;

- Estabilizar as paredes do poço, mecânica e quimicamente;

- Manter os sólidos em suspensão durante a interrupção da perfuração; 
- Exercer pressão hidrostática sobre a formação, de modo a evitar o Kick (influxo de fluidos indesejáveis);

- Resfriar, limpar e lubrificar a coluna de perfuração e a broca;

- Reduzir o atrito entre a coluna de perfuração e o poço ou revestimento;

- Prevenir a hidratação de formações reativas;

Para desempenhar tais funções, os fluidos de perfuração devem ter características desejáveis como:

- Ser estável quimicamente;

- Ser facilmente separado dos cascalhos na superfície;

- Não causar danos à formação produtora;

- Aceitar qualquer tratamento físico e químico;

- Ser bombeável;

- Ter baixo grau de corrosão e abrasão;

- Facilitar interpretações geológicas;

- Apresentar custo compatível com a operação.

Portanto, projetar um fluido de perfuração apropriado para uma determinada situação requer a compreensão das propriedades físicas e químicas deste fluido, em particular sua reologia, e do seu desempenho sob as condições de operação, além das características da zona perfurada, tais como pressão e propriedades permo-porosas.

As propriedades físicas do fluido são mais genéricas e medidas em qualquer tipo de fluido. São elas: densidade, parâmetros reológicos, parâmetros de filtração, teor de sólidos, coeficiente de lubricidade, resistividade e estabilidade elétrica.

Já as propriedades químicas são mais específicas e são determinadas para distinguir certos tipos de fluidos, tais como: $\mathrm{pH}$, teores de cloreto e de bentonita, alcalinidade, excesso de cal, teor de cálcio e de magnésio, concentração de H2S, concentração de potássio.

\subsubsection{Classificação dos Fluidos de Perfuração}

Os fluidos de perfuração são comumente classificados de acordo com o componente principal que constitui a fase contínua ou dispersante, podendo ser:

- à base de gás, 
- à base sintética (óleo, por exemplo),

- à base de água.

A natureza das fases dispersante e dispersa, bem como os componentes básicos e suas quantidades definem não apenas o tipo de fluido, mas também suas características e propriedades.

Os fluidos à base de gás incluem aqueles nos quais o gás é a fase contínua (gás seco), e aqueles onde o gás é a fase descontínua, como em espumas e espumas compactas. Segundo Thomas (2001), algumas situações recomendam a utilização destes fluidos de baixa densidade, tais como em zonas com perdas de circulação severas e formações produtoras com pressão muito baixa ou com grande susceptibilidade a danos. Também em formações muito duras como o basalto ou o diabásio e em regiões com escassez de água ou regiões glaciais com camadas espessas de gelo.

Os fluidos à base sintética, comumente chamados de "oil based mud" são compostos, geralmente, por hidrocarbonetos líquidos em sua fase contínua como: óleo cru, óleo mineral (fração de hidrocarbonetos saturados de C12 a C18 contendo baixas quantidades de aromáticos) e diesel (fração de petróleo destilado, contendo uma mistura não específica de parafinas, olefinas e aromáticos) e a fase descontínua é formada por pequenas gotículas de água ou solução aquosa. Alguns sólidos coloidais, de natureza inorgânica e/ou orgânica, podem compor a fase contínua.

As principais características do fluido à base sintética são: o alto grau de inibição às rochas ativas, a baixíssima taxa de corrosão, propriedades controláveis em altas temperaturas, baixa solubilidade aos sais e alta lubricidade. Contudo, apesar das grandes vantagens citadas, os fluidos sintéticos à base óleo vem sendo empregados com menor frequência na indústria do que os fluidos à base de água devido principalmente ao alto custo inicial e ao grau de poluição.

Os fluidos à base de água, comumente chamados de "water based mud" ou simplesmente base água, consideram principalmente a natureza da água e os aditivos químicos empregados no preparo do fluido. A principal função da água é prover o meio de dispersão para os materiais coloidais, tais como argila e polímeros, que controlam viscosidade, limite de escoamento, força géis e filtrado. A água pode ser doce, dura ou salgada, sendo:

- Doce: salinidade inferior a 1000 ppm de $\mathrm{NaCl}$ equivalente e não necessita de tratamento químico.

- Dura: Presença de sais de Ca e Mg dissolvidos que alteram o desempenho dos aditivos químicos. 
- Salgada: salinidade maior que 1000 ppm de $\mathrm{NaCl}$ equivalente, e pode ser água do mar, ou salgada com adição de sais como $\mathrm{NaCl}$, $\mathrm{KCl}$ ou $\mathrm{CaCl} 2$.

Segundo Machado \& Oliveira (1986), os fluidos base água podem ser compostos por bentonitas, soda cáustica, lignossulfatos, amidos, polímeros, eletrólitos, baritina e hematita, cada um destes em diferentes proporções e com uma determinada função. Por exemplo, a bentonita, a atapulgita e os polímeros funcionam como viscosificantes. A soda cáustica funciona como alcalinizante e floculante. Os amidos, dependendo do tamanho de suas partículas, evita a penetração do fluido na formação (redução de filtrado). Cloretos e hidróxidos à base de sódio, cálcio e potássio são utilizados como inibidores químicos e floculantes, e finalmente, a barita e a hematita, por possuírem elevada densidade dos grãos, são utilizadas como densificantes.

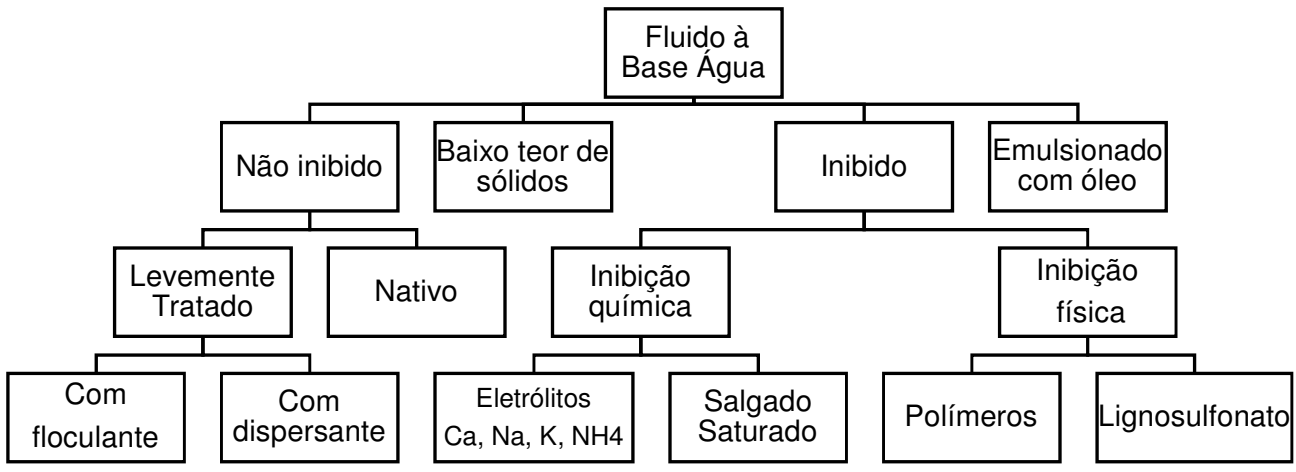

Figura 2.7 - Fluxograma da classificação dos fluidos à base água.

A Figura 2.7 demonstra o esquema da subclassificação dos fluidos à base de água.

Os fluidos não inibidos são usados na perfuração de rochas superficiais compostas na maioria das vezes de sedimentos inconsolidados. Os fluidos com baixo teor de sólidos são utilizados para aumentar a taxa de penetração. Já os fluidos emulsionados com óleo são utilizados para reduzir a densidade e evitar perdas de circulação.

Os fluidos inibidos são programados para perfurar rochas de elevado grau de atividade na presença de água doce. Uma rocha é dita ativa quando interage quimicamente com a água, tornando-se expansível, plástica e dispersível, como é o caso dos folhelhos, ou até mesmo solúvel, como é o caso das rochas evaporíticas. Nos fluidos inibidos, são adicionados produtos químicos tais como eletrólitos e/ou polímeros, que têm a propriedade de retardar ou diminuir estes efeitos. Soluções eletrolíticas, como os cloretos de sódio, de potássio e de cálcio, 
conferem uma inibição química porque reduzem a atividade química da água do fluido de perfuração. Porém, podem reagir com a formação, alterando a composição química.

Os fluidos base água contendo silicatos também são uma boa alternativa na estabilização de formações rochosas como os folhelhos e foram re-introduzidos na indústria do petróleo nos anos 1990 (Ward and Williamson, 1996). Estes fluidos têm a propriedade de se gelificar e precipitar quando expostos aos folhelhos, criando uma fina superfície (reboco) que sela as superfícies levemente fissuradas e fraturadas, prevenindo assim a invasão do fluido de perfuração. Estes fluidos podem ser usados com sais que proporcionem baixas atividades da água gerando altas eficiências de membrana, tipicamente entre 30 e 80\% (van Oort, 2003).

\section{7}

\section{Interação Rocha-Fluido}

O comportamento do folhelho durante a perfuração é definido por uma complexa combinação de processos mecânicos, químicos, térmicos e elétricos.

Esta seção aborda a interação do folhelho com fluido de perfuração do ponto de vista mecânico e correlaciona os fatores químicos e mecânicos que afetam a estabilidade de poços em formação de folhelho. Esses fatores incluem, mas não se limitam a: conteúdo e atividade da água, eficiência da membrana, capacidade de troca catiônica, teor de argila, composição mineralógica, tipo e propriedades do fluido de perfuração, pressão de poros, tensão ao redor do poço e ambientes geológicos.

Os três fatores críticos que controlam as interações rocha-fluido são: a) difusão iônica relacionada à mobilidade da solução salina do fluido de perfuração; b) eficiência da membrana do folhelho, e c) difusão hidráulica relacionada à permeabilidade do folhelho. Os dois primeiros fatores estão associados ao potencial químico e estão inversamente relacionados entre si. O último fator está relacionado ao potencial hidráulico e é diretamente proporcional a este (Bai et al., 2008).

\subsubsection{Mecanismo de Transporte}

O entendimento dos mecanismos de transportes de massa, ou seja, a entrada ou saída de água e solutos nos folhelhos, é de extrema importância, pois estes fenômenos influenciam diretamente nas propriedades da formação, como a 
pressão de poros, deformabilidade, compressibilidade, tensões totais e efetivas, e a resistência da rocha ao redor do poço.

Mody et Hale (1993) estudaram as interações físico-químicas do folhelho com fluido de perfuração até chegar a um modelo integrado de estabilidade de poço. Eles sugerem que a presença de fluido de perfuração pode levar ao transporte de íons e/ou água para dentro ou para fora da formação através de dois mecanismos controladores: a difusão hidráulica e a difusão química.

A difusão hidráulica (ou convecção) representa o fluxo de fluido como resposta ao gradiente de pressão hidráulica entre a pressão que exerce o fluido de perfuração e a pressão de poros da formação. Este fluxo é governado pela lei de Darcy.

A difusão química representa a migração do soluto das zonas de alta concentração para áreas de menor concentração devido à diferença de potencial químico existente ente o fluido de perfuração e o fluido dos poros do folhelho. Esta migração é governada pela lei de Fick.

O fluxo de água devido a um gradiente químico é denominado osmose química. Quando dois fluidos de concentrações diferentes estão separados por uma membrana semi-permeável perfeita, ou seja, que permite somente a passagem de solvente (água) e não de soluto (íons), a água presente na solução menos concentrada flui para a região mais concentrada na tentativa de equilibrar o sistema, gerando assim um gradiente de pressão (Figura 2.8).

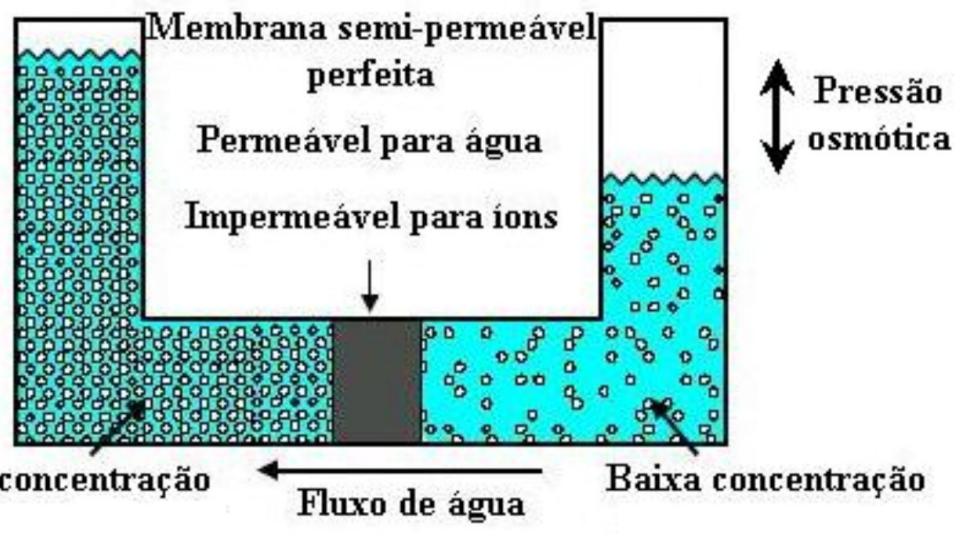

Figura 2.8 - Fluxo osmótico de água através de uma membrana semi-permeável perfeita (Hawkes \& McLellan, 2000)

A pressão necessária a ser aplicada no fluido mais concentrado para evitar o fluxo de água é denominada de pressão osmótica e pode ser obtida pela Equação (2.1) (Katchalsky, et al., 1965, Olsen et al., 1990). 


$$
\Pi=\frac{R T}{V_{w}} \ln \left(\frac{a_{1}}{a_{2}}\right)
$$

Onde:

$R=$ constante universal dos gases $(0,082 \mathrm{I} . \mathrm{atm} / \mathrm{mol} . \mathrm{K})$

$T$ = temperatura absoluta $(\mathrm{K})$

$V_{w}=$ volume parcial molar da água $(0,018 \mathrm{I} / \mathrm{mol})$

$a_{1}=$ atividade química da água na região de baixa concentração iônica

$a_{2}=$ atividade química da água na região de alta concentração iônica $\left(a_{1}>a_{2}\right)$

Considerando o folhelho como uma membrana semi-permeável perfeita numa situação de poço, a pressão osmótica teórica gerada é calculada através da Equação (2.2) (Mody \& Hale, 1993, van Oort, 1995, Tan et al., 2002, Melendez, 2010).

$$
\Pi=\frac{R T}{V_{w}} \ln \left(\frac{A_{f}}{A_{f h}}\right)
$$

Onde:

$A_{f}=$ atividade química do fluido de perfuração

$A_{f h}=$ atividade química do fluido de poros do folhelho

\subsubsection{Atividade Química}

O conceito de atividade química quantifica as diferenças de potencial químico entre o folhelho e o fluido de perfuração, ou seja, é um parâmetro indicador da direção do fluxo de água entre o folhelho e o fluido de perfuração (Figura 2.9). Ela está relacionada com a energia livre das moléculas de água em uma solução. Soluções com alta concentração de soluto apresentam uma baixa atividade da água e soluções com baixa concentração apresentam uma alta atividade da água.

Desta maneira, considerando só a atividade e nenhum processo difusivo, poderia inferir que a utilização de fluidos de perfuração com maior concentração salina (baixas atividades da água) que o fluido dos poros dos folhelhos, geraria um potencial osmótico na formação que é usado para gerar fluxo (osmótico) em direção ao poço perfurado, retirando água da formação, provocando uma queda na pressão de poros, aumentando a tensão efetiva e como consequência melhorando a resistência da formação. 


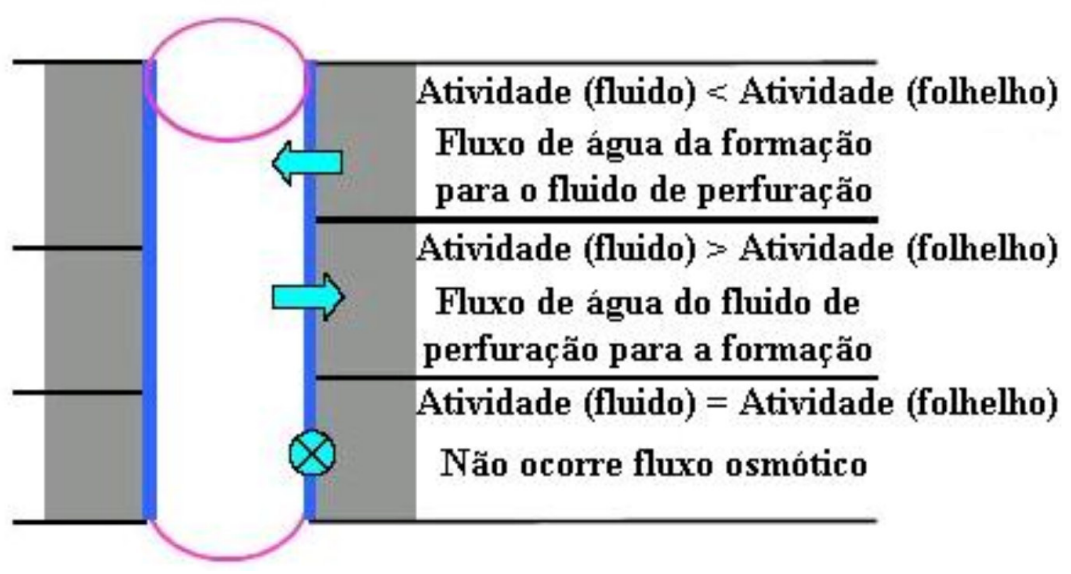

Figura 2.9 - Mecanismo de transporte de água através de uma membrana semi-permeável sob condições de campo (Hawkes \& McLellan, 2000).

Chenevert (1970) aplicou o conceito de atividade química que durante muito tempo se demonstrou eficaz na estabilização de poços perfurados com fluidos base óleo. Neste período, atribuía-se aos folhelhos capacidade de se comportar como uma membrana semi-permeável perfeita. Entretanto, Van Oort (1994), argumenta que o sucesso dos fluidos base óleo, na verdade, é função da formação de barreiras impermeáveis a moderadas pressões diferenciais, devido à alta pressão capilar no contato óleo-fluido dos poros dos folhelhos contribuindo assim para a melhoria da estabilidade (Figura 2.10).

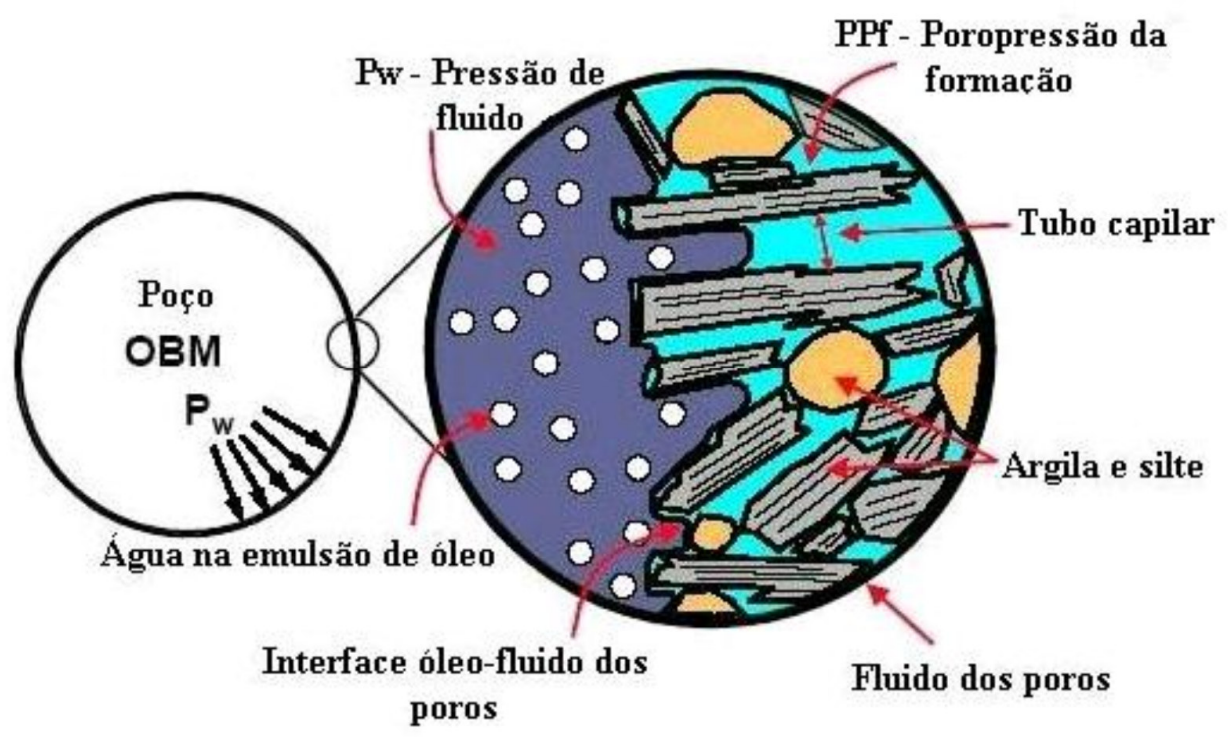

Figura 2.10 - Mecanismo de impermeabilização promovido na interface óleo-fluido dos poros (Dussealt \& Gray, 1992).

Por estas razões, os fluidos de perfuração base óleo ou base óleo sintético foram usados durante muito tempo. No entanto, esses usos foram restritos no 
mundo inteiro devido a legislações ambientais e a seus custos elevados. Sendo assim, os fluidos base óleo foram substituídos por fluidos base água que são ambientalmente viáveis e de menor custo. Como consequência, vários problemas de instabilidade passaram a ser mais frequentes e formulações anteriormente utilizadas com sucesso em fluidos base óleo não se mostraram eficientes.

Em investigações da interação entre o fluido de perfuração base água e o folhelho, pesquisadores como Van Oort et al. (1995), Simpson \& Dearing (2000), Tan et al. (2002), Ewy \& Stankovich (2002), argumentam que o sistema fluidofolhelho não impede a difusão de íons, ou seja, a entrada de íons na formação devido a um gradiente químico ou hidráulico. Logo, o folhelho não atua como uma membrana semi-permeável perfeita. Por conta disto, mudanças na pressão de expansão, no teor de umidade e na pressão de poros podem ocorrer devido ao fluxo de água e íons, sendo estas algumas das causas de instabilidade de poços.

Segundo Amanullah et al. (2014), trabalhos experimentais têm mostrado que, de fato, o aumento da salinidade (diminuição da atividade química) do fluido acima do valor ótimo não é um fator único e preponderante para estabilidade de poços em folhelhos. A utilização de fluidos de composição com alta salinidade pode ter efeitos adversos devido à possibilidade de fraturar o folhelho e, portanto, causar instabilidade no poço. Isso ocorre porque uma salinidade muito alta fará com que a pressão dos poros diminua significativamente devido ao movimento da água da formação para o poço, levando à formação de fissuras dentro da matriz do folhelho.

O potencial osmótico gerado entre o folhelho e o fluido de perfuração em favor da estabilidade é grandemente influenciado pelo movimento de íons para dentro ou fora dos folhelhos; este fato tem estimulado muito interesse para quantificar o impacto do fluxo iônico no potencial osmótico, o que levou a introduzir o conceito da "eficiência de membrana" ou "coeficiente de reflexão" dos folhelhos (Meléndez, 2010).

\subsubsection{Coeficiente de Reflexão (Eficiência de Membrana)}

O coeficiente de reflexão ( $\Re$ ) ou eficiência de membrana está relacionado com as taxas relativas de migração de solvente e soluto no folhelho, ou seja, o termo expressa a capacidade que o folhelho tem de impedir ou não a passagem de íons através de seus poros. 
Van Oort et al. (1995) definiram que o coeficiente de reflexão do folhelho depende da mobilidade da água $\left(v_{a}\right)$ e do soluto $\left(v_{s}\right)$ de acordo com a Equação (2.3) a seguir:

$$
\Re=1-v_{s} / v_{a}
$$

Se o folhelho retiver completamente os íons $\left(v_{s}=0, v_{a} \neq 0\right)$ e permitir somente a passagem de água saindo da formação, é considerado uma membrana semipermeável perfeita, o que torna o coeficiente de reflexão igual a 1 . Este comportamento não é realmente observado com os folhelhos expostos aos fluidos de perfuração base água, pois estes permitem em diferentes graus o ingresso de íons dentro da sua estrutura $\left(v_{s} \neq 0\right)$, assim, os folhelhos são considerados membranas semi-permeáveis imperfeitas, apresentando valores do coeficientes de reflexão entre 0 e 1, exibindo desta maneira, certo nível de seletividade iônica. O coeficiente de reflexão $\Re$ é igual a zero, quando o soluto e o solvente podem fluir livremente através da membrana. Isto ocorre em meios porosos sem propriedade de membrana e neste caso não existe fluxo osmótico e, consequentemente, pressão osmótica.

A verdadeira pressão osmótica $\left(\Delta P_{o s m}\right)$, gerada num sistema onde a membrana seja o folhelho, ou seja, num sistema onde a membrana é semipermeável imperfeita, deve levar em conta a eficiência de membrana ( $\alpha$ ) do mesmo, e pode ser obtida pela Equação (2.4) (Van Oort et al., 1995, Tan et al., 2002, Ewy \& Stankovich, 2002, Al-Bazali, 2005, Melendez,2010).

$$
\Delta P_{o s m}=\Re \Pi
$$

Onde:

$\Delta P_{\text {osm }}=$ pressão osmótica gerada durante ensaio

$\Pi=$ pressão osmótica teórica gerada pelo fluido de perfuração em contato com o folhelho (Equação 2.2)

$\Re=$ coeficiente de reflexão obtido experimentalmente

Diversos pesquisadores, entre eles Van Oort (1997), Ewy \& Stankovich, (2002), Tan et al. (1996), Al-Bazali et al. (2006) e Osuji et al. (2008), estimaram valores do coeficiente de reflexão de diversos tipos de folhelhos expostos a soluções salinas na faixa de $0,003(0,3 \%)$ a $0,25(25 \%)$. 
Segundo Amanullah et al. (2014), o folhelho que possui baixa eficiência de membrana tem mais tendência a se enfraquecer, pois ocorrerá mais permuta iônica. $O$ autor sugere que o poço torna-se mais estável a medida que a eficiência da membrana aumenta e a atividade da água diminui.

\subsubsection{Efeito da permeabilidade}

O estudo dos movimentos difusivos e osmóticos se tornam complexos, pois estes fenômenos possuem fluxos opostos, ou seja, o fluxo de água é dado em uma direção e o fluxo de íons contrariamente a esta. Além disto, a velocidade do transporte é função do gradiente químico imposto e das propriedades do folhelho, como a permeabilidade.

Segundo Meléndez (2010), altas permeabilidades poderiam acabar com o potencial osmótico gerado na formação, como consequência da rápida equalização do gradiente químico entre o folhelho e o fluido de perfuração devido à facilidade na passagem de solutos e água para dentro da estrutura rochosa; que se traduz, em baixos valores do coeficiente de reflexão.

Al-Bazali et al. (2006), em ensaios que visaram avaliar o coeficiente de reflexão em corpos de prova de diferentes permeabilidades e submetidos a diversas soluções salinas (diferentes atividades da água), concluíram que a permeabilidade dos folhelhos influencia na eficiência de membrana e na pressão osmótica gerada. A tendência geral foi que a eficiência de membrana se incrementava quando a permeabilidade do folhelho decrescia. Osuji et al. (2008), em ensaios com o folhelho Atoka, submetidos a diferentes fluidos de perfuração base água, mostraram que a eficiência de membrana é função da permeabilidade e da porosidade dos folhelhos, baixas permeabilidades e baixas porosidades correlacionaram bem com altos coeficientes de reflexão.

\subsubsection{Efeito de Interação Rocha-Fluido na Estabilidade do Poço}

Segundo Amanullah (2014), as interações entre o folhelho e o fluido de perfuração têm vários efeitos sobre diferentes propriedades relacionadas à resistência da rocha. As forças coesivas são as forças que mantêm as partículas de rocha aderindo uma à outra. O autor descreve que quando o filtrado, isto é, a água, penetra nas rochas de folhelho, as forças coesivas são quebradas, reduzidas ou danificadas. Assim, ocorre uma diminuição na resistência da tensão de cisalhamento, que é a requerida para que a falha ocorra. Isso resulta em 
movimento ao longo da fratura existente ou ao longo dos planos fracos levando a problemas como o alargamento. Além disso, quando o filtrado invade o folhelho e o inchamento osmótico acontece, a rocha é amolecida e um aumento no volume de rocha é notado porque a osmose desencadeia o inchaço da superfície da partícula, bem como das camadas de folhelho. Outro efeito da osmose é a pressão criada na rocha devido ao fluxo de fluido dentro da matriz do folhelho. Isso enfraquecerá ainda mais a estrutura coesa.

De um ponto de vista mais mecânico, He et al. (2016) concluíram que a invasão de fluidos e a osmose são mecanismos potencialmente importantes que podem resultar na alteração da pressão do fluido dos poros nas formações dos folhelhos. Quando a atividade da água do fluido de perfuração é menor do que o fluido dos poros, a queda de pressão dos poros por osmose reversa poderia subjugar o impacto da invasão de fluidos dos fluidos de perfuração para a formação e até diminuir a pressão dos poros abaixo do valor inicial em uma escala de tempo de alguns minutos. Uma queda de pressão dos poros pode melhorar a estabilidade do poço devido ao aumento do suporte de fluido de perfuração efetivo, mas a desidratação devido à forte osmose reversa causa o efeito oposto. A invasão de fluidos através de poros do folhelho pode aumentar a pressão de fluido dos poros e, consequentemente, reduzir o suporte efetivo do fluido de perfuração, lubrificar a superfície da fratura ou os planos fracos e causar interações rocha-fluido. Porém, o quadro se agrava quando ocorre invasão destes ao longo de fraturas.

Ajustar a atividade da água dos fluidos de perfuração de forma a aproximar das formações de folhelho, minimizando a invasão de fluidos ao longo de fraturas e outros canais de fluidos, pode reduzir a instabilidade do poço. 


\section{3 Identificação dos Problemas de Instabilidade do Poço}

\section{1}

\section{Introdução}

A revisão dos problemas durante a perfuração e as ações adotadas pela equipe de perfuração fornecem informações importantes para uma análise de estabilidade.

O estudo do comportamento dos problemas de poços através de uma metodologia de análise de dados de perfuração obtidos a partir de operações de campo, permite aos projetistas um melhor conhecimento das peculiaridades do campo analisado e proporcionam um melhor desempenho na execução de futuras operações (Rabelo ,2008).

Mcintyre et al. (2009) descrevem que uma análise dos eventos de perfuração pode ser útil para refinar o modelo de análise de estabilidade, fornecendo insumos-chaves para otimizar o planejamento dos poços e adaptar as práticas de perfuração às condições adversas do campo.

Segundo os estudos desenvolvidos pelos autores, os dados usados para caracterizar os problemas de instabilidade foram: dados de BDP do poço, dados de mudlogging, dados de perfilagem, fluido de perfuração utilizado, litologia e trajetória do poço.

Neste contexto, o objetivo deste capítulo é identificar os possíveis problemas de instabilidade do poço através de uma retroanálise dos dados de perfuração, como Boletim Diário de Perfuração e Dados de Perfil, e da análise de estabilidade do poço a fim de propor um novo tipo de fluido que proporcione um melhor desempenho para futuras operações em poços correlacionados. 


\section{2}

\section{Metodologia}

\subsubsection{Análise do BDP}

O Boletim Diário de Perfuração (BDP) é um registro diário que apresenta descritivamente informações sobre a sequência das atividades e procedimentos que ocorrem em cada fase durante a perfuração.

Nele é relatada a designação, a duração e a profundidade medida do início e do término de cada evento de acordo com o avanço da perfuração. Basicamente as informações que compõem o BDP estão ilustradas na Figura 3.1.

\begin{tabular}{|c|c|c|c|c|c|c|}
\hline $\begin{array}{c}\text { Data do } \\
\text { Relatório }\end{array}$ & $\begin{array}{c}\text { Início } \\
\text { (h) }\end{array}$ & $\begin{array}{c}\text { Duraçäo } \\
\text { (h) }\end{array}$ & $\begin{array}{c}\text { Prof. } \\
\text { Inicial } \\
\text { (m) }\end{array}$ & $\begin{array}{c}\text { Prof. } \\
\text { Final } \\
\text { (m) }\end{array}$ & Descriçäo & $\begin{array}{c}\text { Etapa } \\
\text { (Subcode) }\end{array}$ \\
\hline $08 / 09$ & $14: 30$ & 2 & 2741 & 2749 & Perfurando orientado & $\begin{array}{c}\text { Perfurando } \\
\text { orientado }\end{array}$ \\
\hline $08 / 09$ & $16: 30$ & 0.5 & 2749 & 2754 & Perfurando com rotação da coluna & $\begin{array}{c}\text { Perfurando } \\
\text { rotativo }\end{array}$ \\
\hline $08 / 09$ & $17: 00$ & 1 & 2754 & 2762 & Perfurando orientado & $\begin{array}{c}\text { Perfurando } \\
\text { orientado }\end{array}$ \\
\hline $09 / 09$ & $18: 00$ & 24 & 2762 & 2925 & $\begin{array}{l}\text { Perfurando com rotação da coluna e orientado, } \\
\text { fazendo back reaming antes da conexão e após } \\
\text { perfurar trecho orientado. (20/35kip, 130/170 } \\
\text { rpm, 450gpm pela coluna e 200 gpm pela } \\
\text { booster line, 3350/3420 psi, tpm =6,8 m/h) }\end{array}$ & $\begin{array}{c}\text { Perfurando } \\
\text { orientado }\end{array}$ \\
\hline $10 / 09$ & $18: 00$ & 5 & 2925 & 2961 & $\begin{array}{l}\text { Perfurando com rotação da coluna e orientado, } \\
\text { fazendo back reaming antes da conexão e após } \\
\text { perfurar trecho orientado. (20/35kip, 130/170 } \\
\text { rpm, 450gpm pela coluna e 200 gpm pela } \\
\text { booster line, 3350/3420 psi, tpm =7,2 m/h) }\end{array}$ & $\begin{array}{c}\text { Perfurando } \\
\text { orientado }\end{array}$ \\
\hline
\end{tabular}

Figura 3.1 - Boletim diário de perfuração (Tavares, 2006).

É um documento imprescindível para elaboração de uma retroanálise, pois nele contém registros que servem de guia para interpretação de dados. Podem servir também como informação de correlação para elaboração do projeto do poço, bem como do seu planejamento (Miura et al., 1991; Miura et al., 2003).

$\mathrm{Na}$ literatura, existem diversas metodologias para a identificação de problemas de perfuração a partir do estudo dos BDP(s) dos poços analisados.

Miura et al. (1991;2003), por exemplo, propõe uma metodologia cuja finalidade é a exploração do grande potencial de informação contida no BDP para gerar o conhecimento sobre questões relativas aos problemas que ocorrem durante a perfuração. Na Figura 3.2 são apresentadas as seis etapas da metodologia proposta por ele.

Com o objetivo de otimizar o tempo gasto no processo de identificação dos problemas de perfuração, Rabelo (2008) propôs uma metodologia para a classificação automatizada dos textos do BDP, através de uma elaboração de um 
dicionário de problemas que contenha anormalidades que podem ocorrer durante a perfuração de um poço.

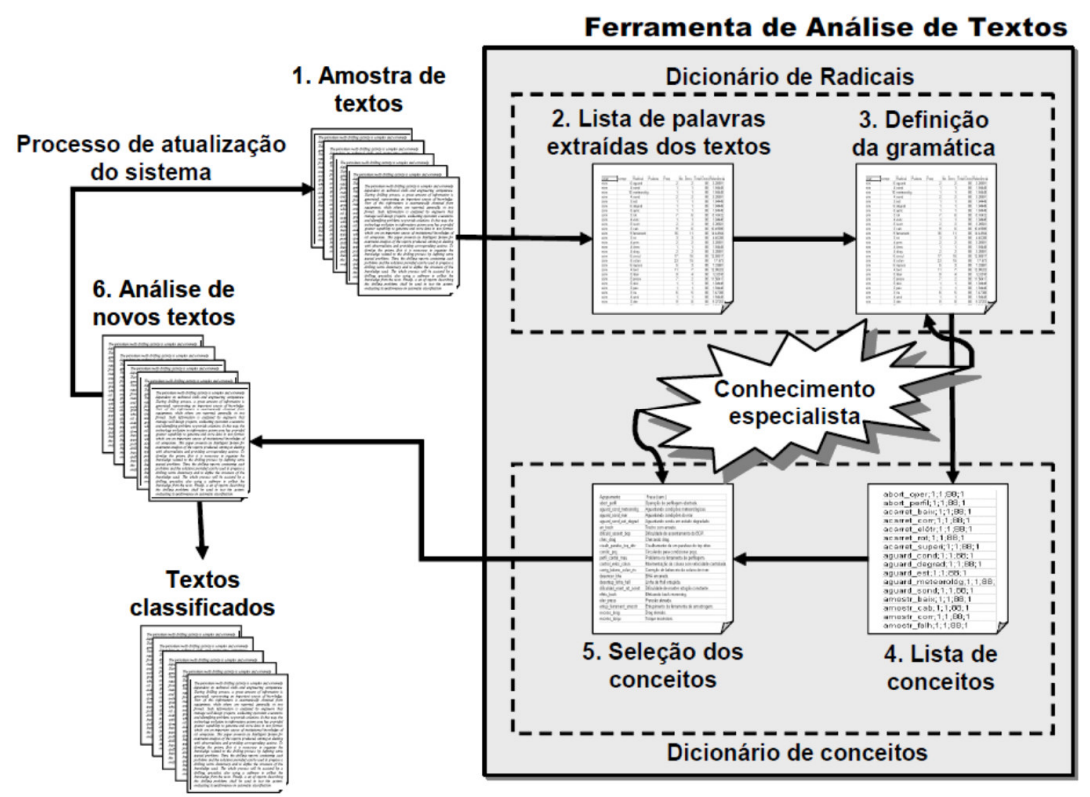

Figura 3.2 - Metodologia para classificação e análise dos boletins (Miura et al., 2003).

A partir dos dados registrados no BDP pode-se construir um gráfico da profundidade versus tempo, chamado por alguns autores como Gráfico de Acompanhamento Diário do Poço, a fim de visualizar os eventos de perfuração importantes, auxiliando no estudo de estabilidade.

Para construir o gráfico, os registros referentes aos eventos, experiências de perfuração e ações corretivas devem ser sistematicamente coletadas e utilizadas para gerar um banco de dados de risco de perfuração.

Segundo Argote (2012), este gráfico permite que as experiências de perfuração sejam apresentadas de forma estruturada e organizada em função da profundidade perfurada, além de estabelecer uma ligação entre as experiências de perfuração de poços com formações específicas, práticas e atividades de perfuração.

Em suma, o gráfico da profundidade versus o tempo do poço é uma ferramenta ideal para: identificar a falha de um poço em particular; distinguir problemas relacionados com a prática de perfuração inadequada daqueles que são afetados pela instabilidade da formação; revelar quando e onde as atividades de perfuração ocorrem. 


\subsubsection{Análise dos Perfis}

Os perfis de poço são medidas das características da formação (elétrica, acústicas e radioativas) obtidas pelo deslocamento ascensional, constante e uniforme da sonda. A interpretação dos perfis de poço permite uma avaliação da formação em intervalos maiores e em condições reais do poço. No entanto a sua aplicação requer informações adicionais, tais como informações da área estudada (estudos geológicos, geofísicos, informações dos poços vizinhos), características das ferramentas de perfilagem (tipo, precisão e alcance) e as condições em que foram realizadas (condições do poço e características do fluido de perfuração).

. Os perfis que geralmente estão disponíveis são: Gamma Ray, Perfil Sônico, Caliper e Densidade da Formação.

- Gamma Ray: O perfil de Raios Gama mede a radioatividade natural das formações. Este perfil reflete o conteúdo de sequências argilosas em virtude da concentração de elementos radioativos presentes nos minerais argilosos dos folhelhos. A medida do perfil é expressa em unidade padrão API, que é a medida da radioatividade de uma rocha padrão com quantidades determinadas de tório, urânio e potássio. Os folhelhos apresentam normalmente alto teor de K40, razão pela qual esse perfil tem grande importância na identificação dos folhelhos entre as rochas não argilosas, ressalvadas as demais condições de enriquecimento por outros minerais radioativos (Tório, Césio, Polônio, Irídio, etc.) (Rocha \& Azevedo, 2007).

- Perfil Sônico: Utilizam a metodologia de medições do tempo de trânsito de um pulso acústico entre dois pontos fixos de uma formação no poço. A velocidade do som é maior nos sólidos do que nos líquidos e nos gases. Por isso, para meios com velocidades maiores, os tempos de trânsito são menores. Se uma rocha, entre duas semelhantes, contém maior quantidade de fluidos nos seus poros (maior porosidade), então o tempo de trânsito do pulso será maior. Por outro lado, as zonas de fratura também podem ser identificadas devido a um maior tempo de trânsito do pulso para alcançar o receptor (ou receptores). Devido à essas características, as principais aplicações do perfil sônico têm sido na estimativa da densidade (indiretamente), da porosidade intergranular (com a equação de Wyllie), na identificação de zonas fraturadas (Schlumberger, 1998) e na calibração da sísmica de superfcie. 
- Caliper: Perfil que registra o diâmetro do poço em qualquer profundidade e fornece de maneira indireta, uma indicação de estabilidade do poço. A ferramenta tem um, dois, três ou seis braços que se expandem e se contraem para ajustarem-se à parede do poço. Um exemplo típico é demonstrado na Figura 3.3.

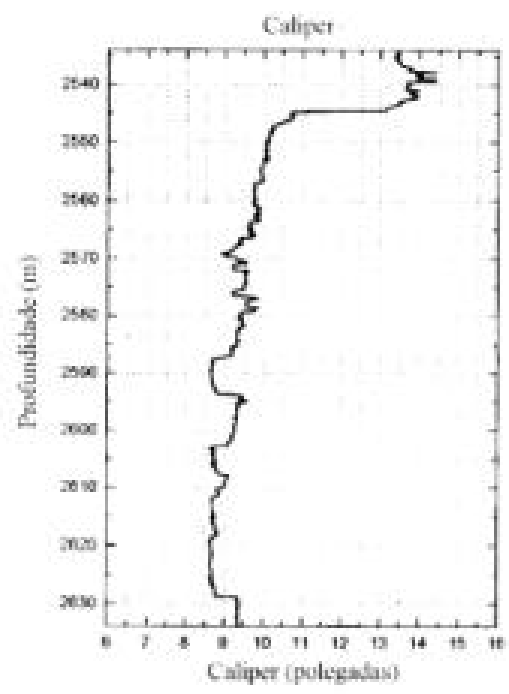

Figura 3.3 - Exemplo típico de um perfil Caliper.

- Densidade: O perfil densidade é um registro continuo das variações da massa específica das rochas atravessadas por um poço. As ferramentas de densidade são utilizadas para medir a densidade de elétrons da formação e, por correções litológicas apropriadas, esse valor é convertido para massa específica com razoável acurácia. Embora de grande utilidade, alguns fatores existentes limitam a utilização do perfil densidade para fins de determinação do gradiente de sobrecarga. Entre eles, pode-se citar o fato do perfil ser normalmente corrido apenas em zonas de interesse e não ao longo de todo o poço, devido ao seu alto custo, e também as grandes imprecisões dos valores medidos em poços alargados (Azevedo, 2011).

\subsubsection{Análise de Estabilidade}

Com o intuito de identificar os mecanismos que causam a instabilidade do poço e sugerir como os poços devem ser perfurados futuramente de maneira mais apropriada e eficiente, os problemas e eventos de instabilidades devem ser incorporados para calibrar e validar a análise de estabilidade do poço. 
A análise de estabilidade do poço foi determinada através do software de sistema de estabilidade de poços SEST (Sistema de ESTabilidade versão 5.72) criado pelo GTEP da PUC-Rio, em conjunto com a PETROBRAS, cujo principal objetivo é a avaliação da janela operacional de peso de fluido de perfuração para o projeto de poço através dos gradientes de pressão de poros, colapso e fratura (inferiores e superiores), estimada em função dos perfis do poço e eventos de instabilidade.

A metodologia para determinar a análise de estabilidade seguiu a sequência de cálculo dos módulos estabelecidos na estrutura do software, definidos como: Perfis, Sobrecarga, Pressão de Poros, Propriedades Mecânicas, Tensões In Situ e Gradientes, que permitem a definição de perfis não disponíveis, são eles: cálculo do gradiente de Sobrecarga, cálculo do gradiente de Pressão de Poros, estimativa das Propriedades Mecânicas, estimativa das Tensões In Situ e o cálculo dos gradientes de Colapso e Fratura, respectivamente.

\subsubsection{Módulo de Perfis}

No módulo de perfis são carregados os perfis do poço no SEST (Figura 3.4) para estimar por meio de correlações presentes na literatura, as informações iniciais para o cálculo dos parâmetros necessários para obter a janela operacional de estabilidade. Os perfis que geralmente estão disponíveis são: Tempo de trânsito compressional (dtc), Resistividade, Gamma Ray, Caliper e Densidade da formação, e por meio de correlações presentes na literatura são definidos os demais perfis, como: Tempo de trânsito da onda cisalhante (dts), Tempo de trânsito da onda compressional da matriz (dtmc), Tempo de trânsito da onda cisalhante da matriz (dtms), Volume de argila, Densidade dos grãos e Porosidade.

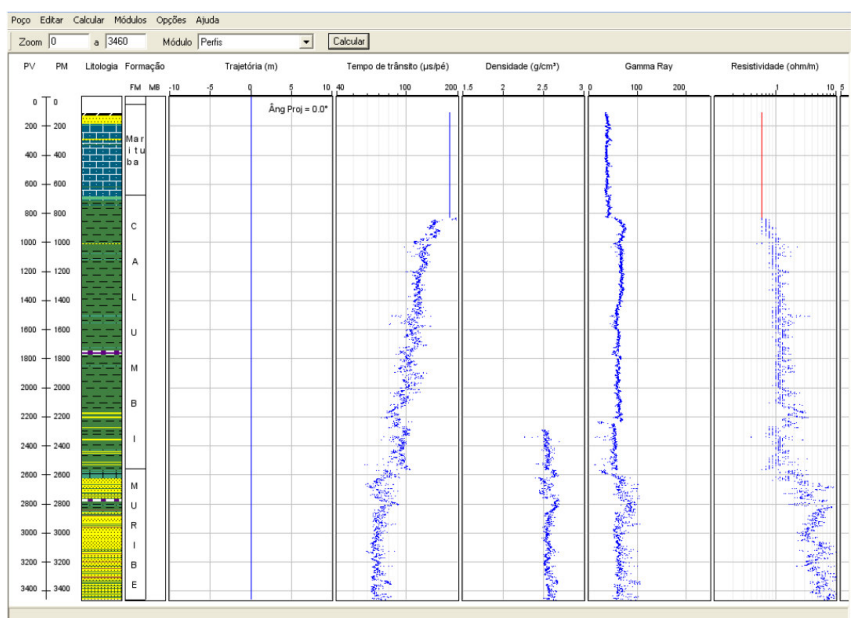

Figura 3.4 - Módulo de Perfis (SEST, 2012). 


\subsubsection{Módulo de Sobrecarga}

O módulo de sobrecarga tem como objetivo a obtenção do gradiente de sobrecarga. A pressão de sobrecarga pode ser calculada através do somatório como mostra a Equação (3.1), já expressa em unidades de campo.

$$
\sigma_{o v}=1,422\left(\rho_{w} Z_{w}+\sum_{0}^{n} \rho_{b i} \Delta Z_{i}\right)
$$

Onde:

$$
\begin{aligned}
& \sigma_{o v}=\text { pressão de sobrecarga }(\mathrm{psi}) \\
& \rho_{b i}=\text { densidade de cada camada da formação }\left(\mathrm{g} / \mathrm{cm}^{3}\right) \\
& \rho_{w}=\text { densidade da água do mar }\left(\mathrm{g} / \mathrm{cm}^{3}\right) \\
& Z_{w}=\text { lâmina d'água }(\mathrm{m}) \\
& \Delta Z_{i}=\text { intervalo de profundidade }(\mathrm{m})
\end{aligned}
$$

Portanto, é necessário dispor-se do perfil de densidade da formação. Contudo, normalmente, este perfil não é corrido nas regiões superiores do poço e raramente está disponível em toda a sua extensão, o que tem conduzido a sua obtenção por meio de correlações presentes na literatura a partir do tempo de trânsito descritas, por exemplo, por Gardner (1974) e Bellotti \& Garcia (1978).

A estimativa de densidade da formação descrita por Gardner (1974) é um dos métodos mais utilizados na indústria do petróleo devido à sua simplicidade pois necessita apenas dos dados de tempo de trânsito acústico, conforme apresentada na Equação (3.2):

$$
\rho_{f}=a\left(\frac{10^{6}}{d t c}\right)^{b}
$$

Onde:

$\rho_{f}=$ densidade da formação $\left(\mathrm{g} / \mathrm{cm}^{3}\right)$

$d t c=$ tempo de trânsito compressional ( $\mu \mathrm{s} /$ pé)

$a$ e $b=$ são constantes empíricas que devem ser calibradas para a área de estudo. Para o Golfo do México as constantes a e b foram estimadas em 0,23 e 0,25 , respectivamente.

Já Belloti \& Giacca (1978) correlacionaram a densidade da formação com o tempo de trânsito compressional (dtc) e tempo de trânsito compressional da matriz (dtmc). Os autores consideram os cálculos para formações cimentadas e 
compactas e para formações não cimentadas, descritos nas Equações (3.3) e (3.4), respectivamente:

$$
\begin{gathered}
\rho_{f}=3,28-\left(\frac{d t c}{89}\right), \text { para } d t c \leq 100 \mu \mathrm{s} / \text { pé } \\
\rho_{f}=2,75-2,11\left(\frac{d t c-d t m c}{d t c+200}\right), \text { para } d t c>100 \mu \mathrm{s} / \text { pé }
\end{gathered}
$$

Onde:

$\rho_{f}=$ densidade da formação $\left(\mathrm{g} / \mathrm{cm}^{3}\right)$

Após a determinação da pressão de sobrecarga, faz-se necessária a definição do gradiente de sobrecarga. Por fim, o gradiente de sobrecarga para uma determinada profundidade é calculado pela Equação (3.5):

$$
G_{o v}=\frac{\sigma_{o v}}{C Z}
$$

Onde:

$G_{o v}=$ gradiente de sobrecarga

$\sigma_{o v}=$ pressão de sobrecarga

$Z$ = profundidade vertical

$C=$ constante de conversão de unidades

\subsubsection{Módulo de Pressão de Poros}

Este módulo tem como objetivo a determinação do gradiente de pressão de poros. A pressão de poros é definida como a pressão do fluido contido no espaço poroso das rochas.

Em formações de baixa permeabilidade, como os folhelhos, a partir de uma certa profundidade, pode ocorrer o processo de subcompactação. Este processo consiste no aumento da taxa de soterramento e da taxa de redução do volume poroso que passam a ser maiores que o escape do fluido contido dentro dos poros gerando uma possível retenção de fluidos durante o processo de compactação. Como consequência, ocorre um aumento da pressão de poros e a pressão de sobrecarga passa a atuar sobre eles.

$\mathrm{Na}$ literatura, existem várias correlações para obter o gradiente de poros, porém o método de Eaton (1975) é, sem dúvida, a correlação mais amplamente utilizada até o momento. $O$ método propõe a determinação do gradiente de 
pressão de poros tanto pelo perfil de tempo de trânsito compressional quanto pelo perfil de resistividade e tem como fundamento principal o processo de compactação através do traço de uma linha de tendência.

O tempo de trânsito decresce à medida que a profundidade aumenta, e a porosidade também decresce. Ou seja, à medida que a profundidade aumenta, a tendência de zonas normalmente compactadas é se tornarem cada vez menos porosas. No entanto, em zonas normalmente compactadas, principalmente em regiões com pressões de poros anormalmente altas, a porosidade não mantém a tendência de decréscimo. Este é o comportamento que permite a identificação de zonas de pressões anormais conforme o método de Eaton mostrado na Figura 3.5 .
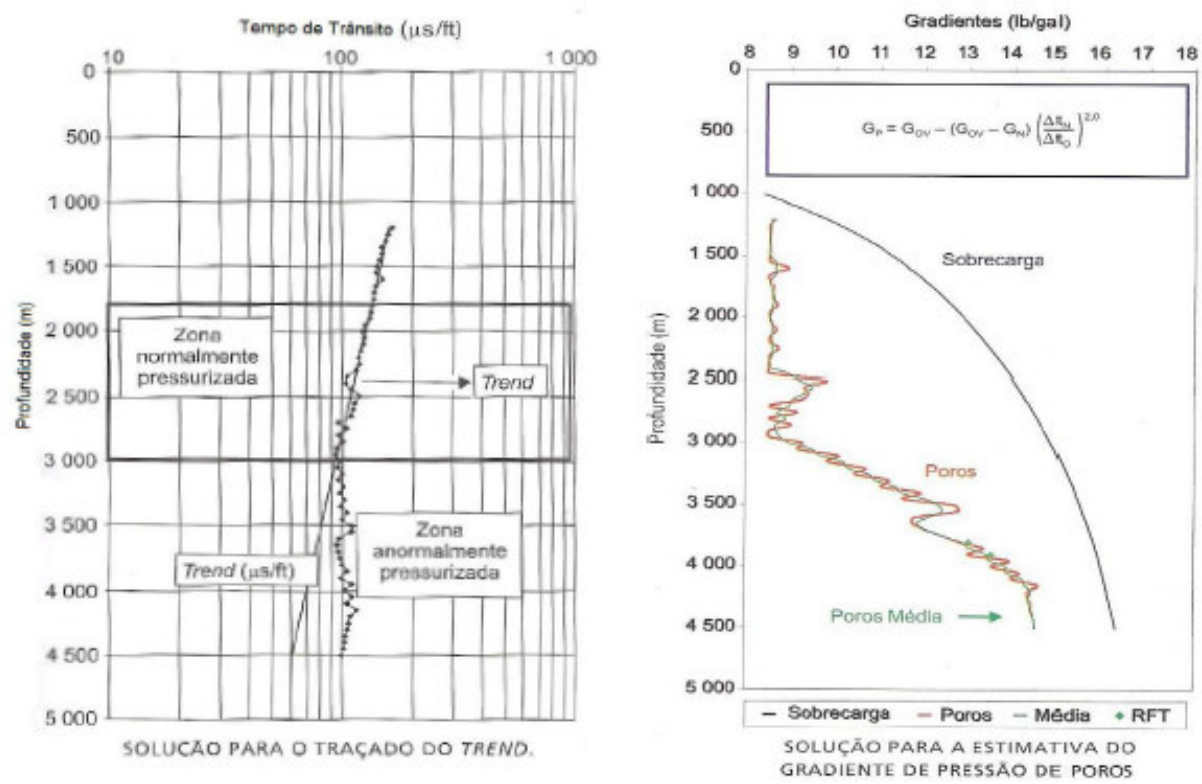

Figura 3.5 - Método de Eaton para estimar a Pressão de Poros (Rocha \& Azevedo, 2007).

Finalmente, em posse do perfil de tempo de trânsito, o método de Eaton é descrito pela Equação (3.6).

$$
G_{P}=G_{o v}-\left(G_{o v}-G_{N}\right)+\left(\frac{d t c_{n o r m a l}}{d t c_{o b s}}\right)^{e x p}
$$

Onde:

$G_{P}=$ gradiente de pressão de poros (lb/gal)

$G_{o v}=$ gradiente de sobrecarga $(\mathrm{lb} / \mathrm{gal})$

$G_{N}=$ gradiente de pressão de poros normal na área (lb/gal)

$d t c_{\text {normal }}=$ tempo de trânsito da onda compressional para a linha de tendência de compactação normal ( $\mu$ s/pé) 
$d t c_{o b s}=$ tempo de trânsito da onda compressional observado ( $\left.\mu \mathrm{s} / \mathrm{pé}\right) ;$

$\exp =$ expoente de Eaton

\subsubsection{Propriedades Mecânicas}

Correlações a partir de perfis elétricos e acústicos para determinar as propriedades mecânicas das rochas têm sido amplamente usadas ao invés de resultados de ensaios de laboratório com testemunhos, uma vez que os perfis fornecem informações contínuas do poço e os resultados dos ensaios informações pontuais.

Considerando a rocha um meio homogêneo e isotrópico, os parâmetros elásticos são obtidos em função da velocidade da onda compressional $(V p)$ e cisalhante $(V s)$, do tempo de trânsito da onda compressional $(d t c=1 / V p)$ e cisalhante $(d t s=1 / V s)$, e da densidade da rocha $\left(\rho_{f}\right)$.

As relações entre tensões e deformações de um material elástico são conhecidas como parâmetros elásticos e entre os mais importantes destacam-se: coeficiente de Poisson $(v)$, módulo de Young $(E)$, módulo de cisalhamento $(G)$ e o módulo de compressibilidade dos grãos $\left(K_{S}\right)$, descritas conforme as Equações (3.7), (3.8), (3.9) e (3.10), respectivamente.

$$
\begin{gathered}
v=0,5 \frac{(\mathrm{dts} / \mathrm{dtc})^{2}-2}{(\mathrm{dts} / \mathrm{dtc})^{2}-1} \\
E=2 G(1+v) \\
G=1,34 \times 10^{10} \frac{\rho_{f}}{d t s^{2}} \\
K_{S}=1,34 \times 10^{10} \rho_{f}\left(\frac{1}{d t m c^{2}}-\frac{4}{3 d t m s^{2}}\right)
\end{gathered}
$$

Onde:

$d t s=$ tempo de trânsito cisalhante ( $\mu$ s/pé)

$\mathrm{dtc}=$ tempo de trânsito compressional $(\mu \mathrm{s} /$ pé $)$

$d t m c=$ tempo de trânsito compressional da matriz ( $\mu$ s/pé)

$d t m s$ = tempo de trânsito cisalhante da matriz ( $\mu$ s/pé)

$\rho_{f}=$ densidade da formação $\left(\mathrm{g} / \mathrm{cm}^{3}\right)$ 


$$
\begin{aligned}
& E=\text { módulo de Young (psi) } \\
& G=\text { módulo de cisalhamento (psi) } \\
& K_{S}=\text { módulo de compressibilidade dos grãos (psi) }
\end{aligned}
$$

A pressão de poros não possui eficiência total na sua oposição à tensão total aplicada, devido a estreitamentos existentes no espaço intergranular por efeito da cimentação ou forma dos grãos. Deste modo, Biot propôs o fator de correção $\alpha$ para o efeito da pressão de poros, conforme Equação (3.11):

$$
\sigma^{\prime}=\sigma-\alpha P_{p}
$$

Onde:

$$
\begin{aligned}
& \sigma^{\prime}=\text { tensão efetiva } \\
& \sigma=\text { tensão total } \\
& \alpha=\text { fator de correção } \\
& P_{p}=\text { pressão de poros }
\end{aligned}
$$

Onde $\alpha$ varia de 0 a 1 e seu valor depende da geometria do poro e das propriedades físicas dos constituintes sólidos da rocha. Para esta dissertação, o coeficiente de Biot foi adotado como $\alpha=1$.

O valor para o ângulo de atrito pode ser adotado para todas as rochas igual a $\varnothing=30^{\circ}$ ou pode ser usada alguma das correlações de Lal (1999) e Plumb (1994).

Coates e Denoo (1981) propuseram uma correlação empírica para estimar a coesão $(c)$ a partir do volume de argila $\left(V_{c l}\right)$, do módulo de Young $(E)$ e da compressibilidade $\left(C_{b}\right)$ através de dados de rochas sedimentares, conforme as Equação (3.12) e (3.13):

$$
\begin{gathered}
c=0,025 \frac{\left[0,0045\left(1-V_{c l}\right)+0,008 V_{c l}\right] E}{10^{6} C_{b}} \\
C_{b}=\frac{1}{K_{b}} \\
K_{b}=1,34 \times 10^{10} \rho_{f}\left(\frac{1}{d t c^{2}}-\frac{4}{3 d t s^{2}}\right)
\end{gathered}
$$

Onde:

$c=$ coesão (psi) 


$$
\begin{aligned}
& C_{b}=\text { compressibilidade }(1 / \mathrm{psi}) \\
& d t s=\text { tempo de trânsito cisalhante }(\mu \mathrm{s} / \mathrm{pé}) \\
& \mathrm{dtc}=\text { tempo de trânsito compressional }(\mu \mathrm{s} / \mathrm{pé}) \\
& E=\text { módulo de Young (psi) } \\
& K_{b}=\text { módulo de deformação volumétrica }(\mathrm{psi}) \\
& V_{c l}=\text { volume unitário de argila }
\end{aligned}
$$

A resistência à compressão simples (UCS) é calculada em função da combinação de um par de parâmetros de resistência enquanto o terceiro parâmetro é calculado em função desses dois parâmetros escolhidos.

$\mathrm{Na}$ literatura existem diversas correlações empíricas para estimativa da resistência à compressão simples conforme a composição litológica da rocha em análise. Para determinação da mesma, o SEST se dispõe das correlações propostas por Brehm (2004), Militzer \& Stoll (173), Chang (2004) e Lal (1999), todas em função do tempo de trânsito compressional. Nesta dissertação o cálculo se deu por meio da Equação (3.15), cuja resistência à compressão simples é função do ângulo de atrito $(\phi)$ e da coesão (c).

$$
U C S=2 c \tan \left(\frac{\pi}{4}+\frac{\phi}{2}\right), \text { em psi }
$$

A resistência à tração é calculada pela Equação (3.16):

$$
\sigma_{t}=\frac{U C S}{12}, \text { em psi }
$$

Por último, a permeabilidade é obtida através da correlação com a porosidade $(\varnothing)$ conforme Equação (3.17):

$$
K=54,4 \frac{n^{2}}{(1-n)^{2}}, \mathrm{em} \mathrm{mD}
$$

\subsubsection{Tensões In Situ}

Toda análise de estabilidade de poços requer a determinação das tensões in situ, da pressão de poros e de um critério de falha das rochas perfuradas. No entanto, a magnitude das tensões in situ é provavelmente um dos parâmetros de entrada mais importantes e insuficientemente conhecidos (Argote, 2012). 
As formações existentes em subsuperfície estão submetidas a um estado de tensões compressivo. Esse estado de tensão é chamado de tensão in situ, sendo formada por três tensões mutuamente ortogonais entre si, uma vertical $\left(\sigma_{v}\right)$ e duas horizontais, sendo uma horizontal mínima $\left(\sigma_{h}\right)$ e a outra horizontal máxima $\left(\sigma_{H}\right)$. De acordo com Rocha \& Azevedo (2007), a tensão vertical in situ $\left(\sigma_{v}\right)$ é dada pelo peso das camadas de rochas sobrejacentes a um bloco de rocha no subsolo, geralmente assumida igual à pressão de sobrecarga $\left(\sigma_{o v}\right)$. Em resposta a esse carregamento, o elemento de rocha tende a se deformar lateralmente, sendo, contudo, limitado pelos elementos vizinhos. Isto resulta no aparecimento das tensões in situ horizontais, $\left(\sigma_{H}\right)$ e $\left(\sigma_{h}\right)$, as quais podem ou não ser iguais.

Dentre as tensões in situ, a tensão vertical é a maior tensão atuante na formação e, também, a mais fácil de ser determinada. O cálculo de seu valor é realizado através do estabelecimento da densidade das formações conforme demonstrado no item 3.2.3.2.

A pressão de poros atua em todas as direções dentro dos poros de uma rocha, ajudando a suportar grande parcela da tensão total aplicada. Dessa forma, a tensão efetiva atuante na matriz da rocha que deverá ser levada em consideração para análises da resistência das formações é igual a tensão total menos a pressão de poros, conforme a Equação (3.18) de Terzaghi.

$$
\sigma^{\prime}=\sigma-P_{p}
$$

Onde:

$\sigma^{\prime}=$ tensão efetiva

$\sigma=$ tensão total

$P_{p}=$ pressão de poros

As tensões horizontais são uma resposta ao carregamento vertical, e para efeitos desta análise, assumindo a condição de bacia com deformação lateral nula, podem ser escritas conforme Equação (3.19):

$$
\sigma_{h}^{\prime}=\sigma_{H}^{\prime}=k \sigma_{v}^{\prime}
$$

Onde:

$\sigma_{h}^{\prime}=$ tensão horizontal mínima efetiva

$\sigma_{H}^{\prime}=$ tensão horizontal máxima efetiva

$\sigma^{\prime}{ }_{v}=$ tensão vertical efetiva

$k=$ razão entre a tensão horizontal efetiva e a tensão vertical efetiva 
Sendo que $0 k$, por sua vez, é calculado em termos do coeficiente de Poisson $(v)$, conforme Equação (3.20):

$$
k=\frac{v}{1-v}
$$

Entretanto, é importante dizer que em condições especiais, tais como áreas tectonicamente ativas, presença de domos salinos e regiões sujeitas ao aumento ou à redução drástica de temperatura, tanto a magnitude quanto a direção das tensões podem ser afetadas e, considerando esses efeitos, as tensões horizontais podem ser diferentes entre si, além de, em alguns casos, uma das tensões horizontais poder representar a maior tensão atuante na formação.

Diferentemente da tensão vertical, a obtenção da tensão horizontal máxima e mínima apresenta grande dificuldade, uma vez que os valores dessas tensões não são obtidos facilmente a partir de modelos matemáticos (Fjær,2008). Para sua caracterização, podem ser realizadas análises referentes à determinação de suas direções e também testes afim de obter suas magnitudes.

O estabelecimento das direções das tensões horizontais é baseado na detecção de falhas nas paredes do poço, pois as direções dessas falhas, em uma situação ideal, são unicamente governadas pelas direções das duas tensões horizontais principais. Para obtenção dessas direções são empregadas ferramentas de perfilagem, principalmente perfil Caliper e perfis de imagens elétricos e acústicos. Esses instrumentos são capazes de visualizar a direção de breakout, isto é, zonas de desmoronamento e ruptura por cisalhamento, determinando então as direções das tensões horizontais. A Figura 3.6 traz um exemplo de um breakout incipiente e de uma fratura induzida encontrado no perfil de imagem na Bacia de Neuquén.

Com relação às magnitudes, os valores são obtidos de forma distinta para a tensão horizontal mínima e máxima. Para determinação da tensão horizontal mínima, o único método eficaz é fraturar a formação e registrar a pressão em que a fratura se fecha (teste de LOT). Isto requer que a fratura tenha penetrado na formação por uma distância longa o suficiente para que apenas a resistência das tensões horizontais in situ seja sentida. Já a tensão horizontal máxima é realizada empregando equações que utilizam dados obtidos a partir de ensaios de fraturamento a fim de que estimativas de seu valor possam ser obtidas. 


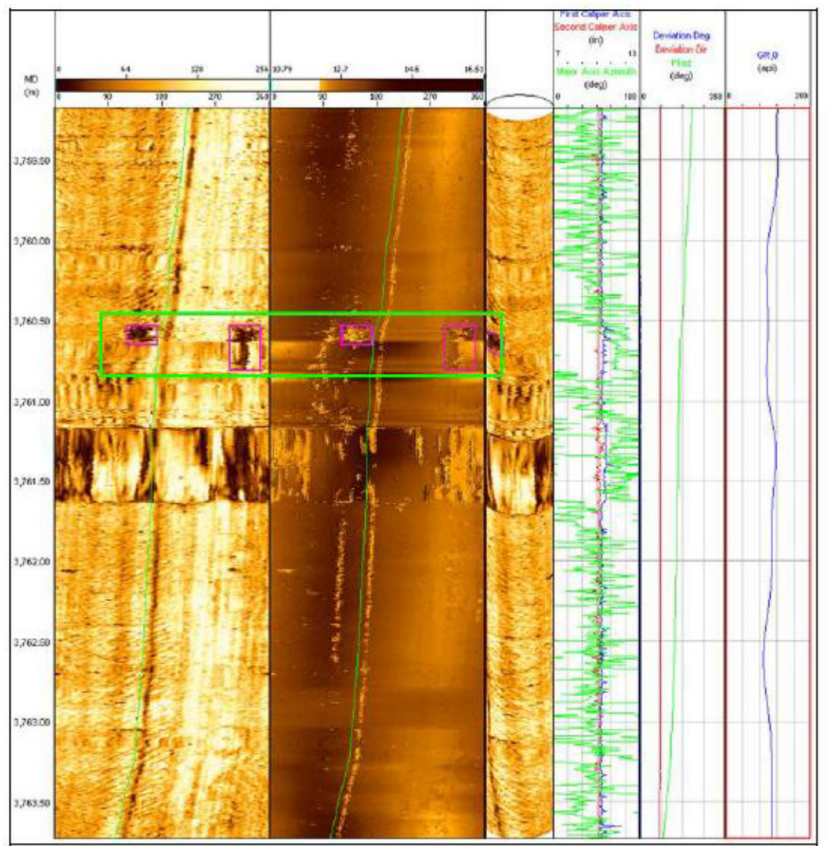

Figura 3.6 - Breakouts e fraturas naturais e induzidas no perfil de imagem (Argote, 2012).

\subsubsection{Gradientes}

O módulo de gradientes do SEST permite a obtenção dos gradientes de colapso superior e inferior e fratura inferior e superior para toda a extensão do poço mediante ao critério de ruptura adotado.

O gradiente de colapso está relacionado ao conceito de pressão de colapso, a qual pode ser entendida como a pressão que faz com que a parede do poço falhe por cisalhamento. A falha por colapso pode estar relacionada tanto a um peso de fluido insuficiente como a um peso de fluido excessivo, gerando falha por colapso inferior e superior, respectivamente, e levando à definição de gradientes de colapso inferior e superior. A determinação do valor do gradiente de colapso, mais especificamente o gradiente de colapso inferior, exige um conhecimento do comportamento das rochas em subsuperfície.

Por outro lado, o gradiente de fratura é a pressão que leva a falha da rocha por tração. Segundo Rocha e Azevedo (2007), da mesma forma que acontece para o colapso da formação, a fratura pode ocorrer tanto em função da utilização de um baixo peso de fluido de perfuração, levando a uma falha devido à fratura inferior, quanto por alto peso de fluido de perfuração, ocorrendo uma fratura superior. O gradiente de fratura pode ser determinado basicamente de duas formas: por meio de medições diretas ou usando técnicas de cálculo baseadas em modelos teóricos e empíricos. 
A medição direta dos gradientes de fratura é geralmente feita através de testes de absorção clássico (LOT) ou de teste de absorção estendido (ELOT), em que o fluido de perfuração é pressurizado de maneira controlada no reservatório. A pressão de absorção é utilizada como uma aproximação para o cálculo do gradiente de fratura, pois esse teste estima o gradiente máximo de pressão que o poço pode ser submetido sem que ocorra perda de circulação.

Ao contrário dos métodos diretos, os métodos indiretos permitem a estimativa do gradiente de fratura ao longo de todo o poço. No entanto, a aplicação desses métodos torna-se difícil pois necessita de conhecimento, nem sempre disponível sobre as formações.

Rocha \& Azevedo (2007) afirmam que o gradiente de fratura, em poços verticais, pode ser estimado utilizando o método da tensão mínima, pois é o método mais representativo das tensões atuantes nas regiões mais distantes do poço. O estado de tensão é examinado em frente à fratura e não próximo à parede do poço, admite-se hipoteticamente que a rocha não possui resistência à tração e que a fratura ocorre quando a pressão dentro do poço atinge a tensão in situ para que a propagação da fratura ocorra. Considerando que a menor tensão in situ é a tensão horizontal mínima $\left(\sigma_{h}\right)$ e que $P_{W}$ é a pressão dentro do poço que leva à fratura da formação, tem-se a Equação (3.21):

$$
P_{W}=\sigma_{h}
$$

Outro método indireto para estimativa do gradiente de fratura são as correlações específicas que se baseiam na utilização do gradiente de sobrecarga como parâmetro, pois além de ser um valor de tensão in situ, o gradiente de sobrecarga é função da profundidade do poço e da lâmina d'água, fazendo dele uma boa correlação direta com testes de absorção disponíveis na área.

Quando se têm dados de sobrecarga e LOT, basta plotar um gráfico do LOT versus sobrecarga e traçar a linha de tendência que forneça o melhor coeficiente de correlação. Esta linha estima o gradiente de fratura ao longo de todo poço.

Outra consideração importante para obtenção da janela operacional é a determinação do fluido de perfuração como penetrante ou não penetrante. Quando a formação é perfurada e o fluido de perfuração é capaz de gerar um reboco eficiente, este é caracterizado como fluido não penetrante e, então, considera-se que a pressão de poros no interior da rocha é a própria pressão de poros original da rocha, enquanto que na parede do poço a pressão é igual a pressão do fluido de perfuração (Figura 3.7a). Por outro lado, se o fluido de 
perfuração não é capaz de gerar um reboco eficiente, este é caracterizado como fluido penetrante e nesta condição pode ocorrer fluxo de fluido do poço para a rocha ou da rocha para o poço, a depender do gradiente de pressão. A distribuição de pressão ao redor do poço é representada por uma função logarítmica, como apresentado por Fjaer et al. (1992) e conforme a Figura 3.7b.

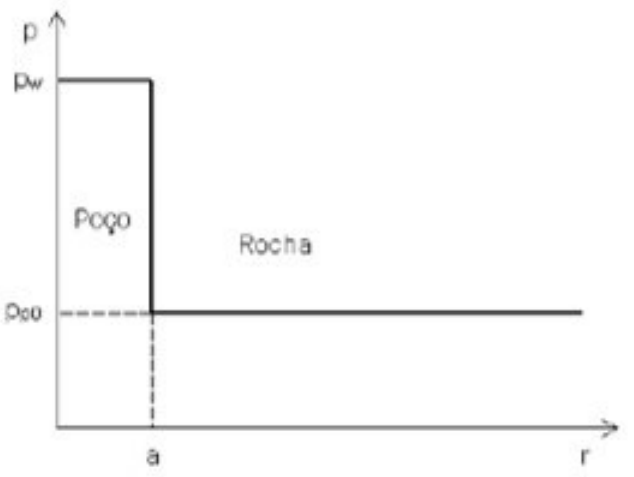

(a)

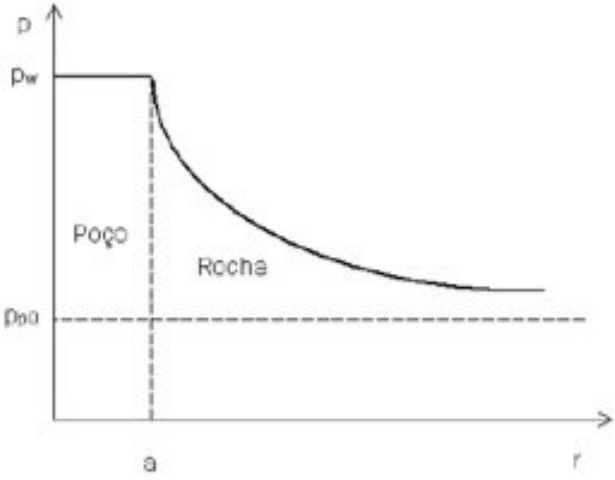

(b)

Figura 3.7 - Distribuição da pressão de poros para fluido não penetrante (a) e para fluido penetrante (b) (SEST, 2012).

Por fim, ao obter os gradientes de colapso superior e inferior e fratura inferior e superior para toda a extensão do poço, é definida a janela operacional conforme Figura 3.8, que determina o intervalo permissível da variação de um peso de fluido de perfuração dentro do poço, respeitando os limites demarcados pelos gradientes de pressões de poros, fratura e colapso, de forma a manter a integridade do mesmo. O limite inferior corresponde ao menor valor entre as curvas de pressão de poros e colapso inferior, enquanto o limite superior é definido pela pressão de fratura.

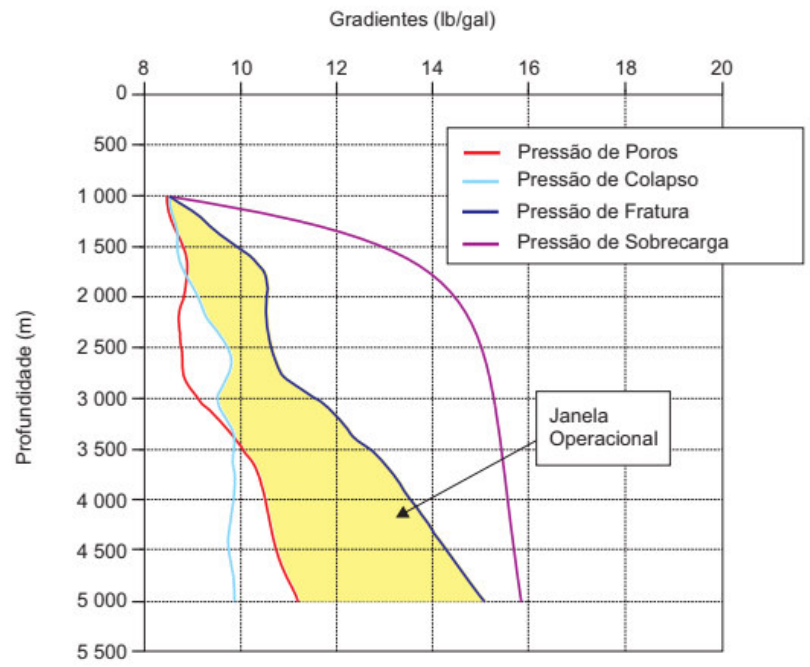

Figura 3.8 - Exemplo típico de uma janela operacional de um poço (Rocha \& Azevedo, 2007). 


\section{3}

\section{Análise e Resultado}

A metodologia proposta foi aplicada no estudo de caso do poço exploratório P-001 cujas informações estão apresentadas na Tabela 3.1.

Tabela 3.1 - Dados do poço analisado.

\begin{tabular}{cccccc}
\hline Nome & $\begin{array}{c}\text { Tipo de } \\
\text { Poço }\end{array}$ & $\begin{array}{c}\text { Mesa Rotativa } \\
(\mathbf{m})\end{array}$ & $\begin{array}{c}\text { Lâmina da } \\
\text { Água }(\mathbf{m})\end{array}$ & $\begin{array}{c}\text { Prof. Medida } \\
(\mathbf{m})\end{array}$ & $\begin{array}{c}\text { Número de } \\
\text { Fases }\end{array}$ \\
\hline P-001 & Vertical & 25 & 2135 & 5603 & 5 \\
\hline
\end{tabular}

Inicialmente, foi realizada a análise do BDP a fim de obter o levantamento dos principais pontos nos quais problemas e eventos de perfuração ocorridos possam estar relacionados à instabilidade do poço em regiões de folhelho.

Geralmente, o BDP é elaborado por diversos técnicos que podem registrar um mesmo evento de perfuração de várias formas distintas. Em vista disso, foi realizado um controle de qualidade dos dados, destacando os pontos que apresentaram eventos de perfuração, tais como: drag, ganho de fluido, gás, kick, perda de fluido, perfilagem, pontos trabalhados, repasse, testemunhagem, topada.

Segundo os registros do BDP, não foram relatados problemas na primeira fase (fase de 36"). Já na fase de 20" (segunda fase), foram constatados pontos críticos que foram trabalhados devido à presença de altos valores de drags.

A fase 13 3/8" (terceira fase) é marcada por aumento de ECD e por conseguinte prisão de coluna a $3787 \mathrm{~m}$. Isto porque com o aumento do ECD, ocorreu transbordamento na secadora de cascalho, sendo necessário reduzir a vazão do fluido. Como consequência, ocorreu a decantação e compactação de cascalho no anular. Com o fim de resolver o problema, a coluna foi trabalhada e repasses foram realizados.

Os principais eventos ocorridos na fase 9 7/8" (quarta fase) foram marcados pela troca de sonda de perfuração devido à alta incidência de tempo não produtivo vinculado a falhas no BOP, optando por um navio sonda com melhor histórico de desempenho operacional. Antes da troca de sonda, constatou-se topada da coluna. Já na nova intervenção, após desvio de poço, por quase toda extensão da fase foram constatados altos valores de drag - e por conseguinte, diversos pontos foram trabalhados - ameaça de prisão e queda de pressão. A fase foi perfurada até a profundidade de $5060 \mathrm{~m}$, onde foi observado alto volume de cascalhos retornado nas peneiras, grande parte deles com indícios de desmoronamento 
(cavings). Posteriormente, foi realizada a perfilagem constatando, de fato, arrombamentos nos trechos entre $4330 \mathrm{~m}$ a $4350 \mathrm{~m}$ e $4375 \mathrm{~m}$ a $4400 \mathrm{~m}$.

Finalmente, na última fase (fase 8 1/2") foram observados drags altíssimos, em torno de $500 \mathrm{klb}$, nos trechos de $5169 \mathrm{~m}$ a $5188 \mathrm{~m}$.

Através da leitura do BDP, foi identificado, ainda, que o fluido de perfuração adotado ao longo de todo o poço foi o fluido sintético base óleo.

Uma vez revisado o BDP, realizou-se a construção do gráfico de profundidade versus tempo, apresentado na Figura 3.9, com o intuito de reconstruir o histórico de perfuração que permita ressaltar a influência dos eventos de perfuração nas curvas de avanço do poço. O gráfico permitiu, ainda, correlacionar os problemas de perfuração com as fases de perfuração e profundidade onde esses ocorreram no poço.

Para um melhor entendimento dos problemas ocorridos no poço, a Figura 3.10 apresenta a correlação dos eventos de perfuração com a litologia, a trajetória do poço e o perfil Caliper. Confirma-se a condição de instabilidade das paredes na fase $97 / 8$, inclusive na fase $81 / 2$ ", devido aos arrombamentos experimentados durante a perfuração. Ressalta-se que a coluna litológica do trecho analisado é composta basicamente por folhelhos.

A ocorrência destes arrombamentos evidencia uma condição de instabilidade das paredes do poço a qual, conforme apresentada na Tabela 2.3 no Capitulo 2 desta dissertação, Rabelo (2008) relaciona a quatro possíveis causas: ação mecânica da coluna, pressão hidráulica excessiva, reatividade da formação ao fluido de perfuração e desmoronamentos. Por sua vez, o mesmo autor relaciona os desmoronamentos a quatro causas: pressão hidrostática insuficiente, ação mecânica da coluna, pressão hidráulica excessiva e dissolução dos domos salinos.

Findas a análise do BDP e a identificação do problema de instabilidade do poço, foi realizada a análise de estabilidade particularmente em regiões de folhelhos a fim de identificar os possíveis agentes causadores do problema de instabilidade.

A análise de estabilidade foi determinada seguindo as sequências de cálculo dos módulos estabelecidos na estrutura do software de simulador de estabilidade SEST em função dos perfis disponíveis, isto é, perfil Gamma Ray, perfil Caliper, perfil do Tempo de Trânsito, perfil de Densidade da Formação, a partir dos quais foram estimadas correlações para determinar os parâmetros necessários para gerar a janela operacional de estabilidade. 
P-001
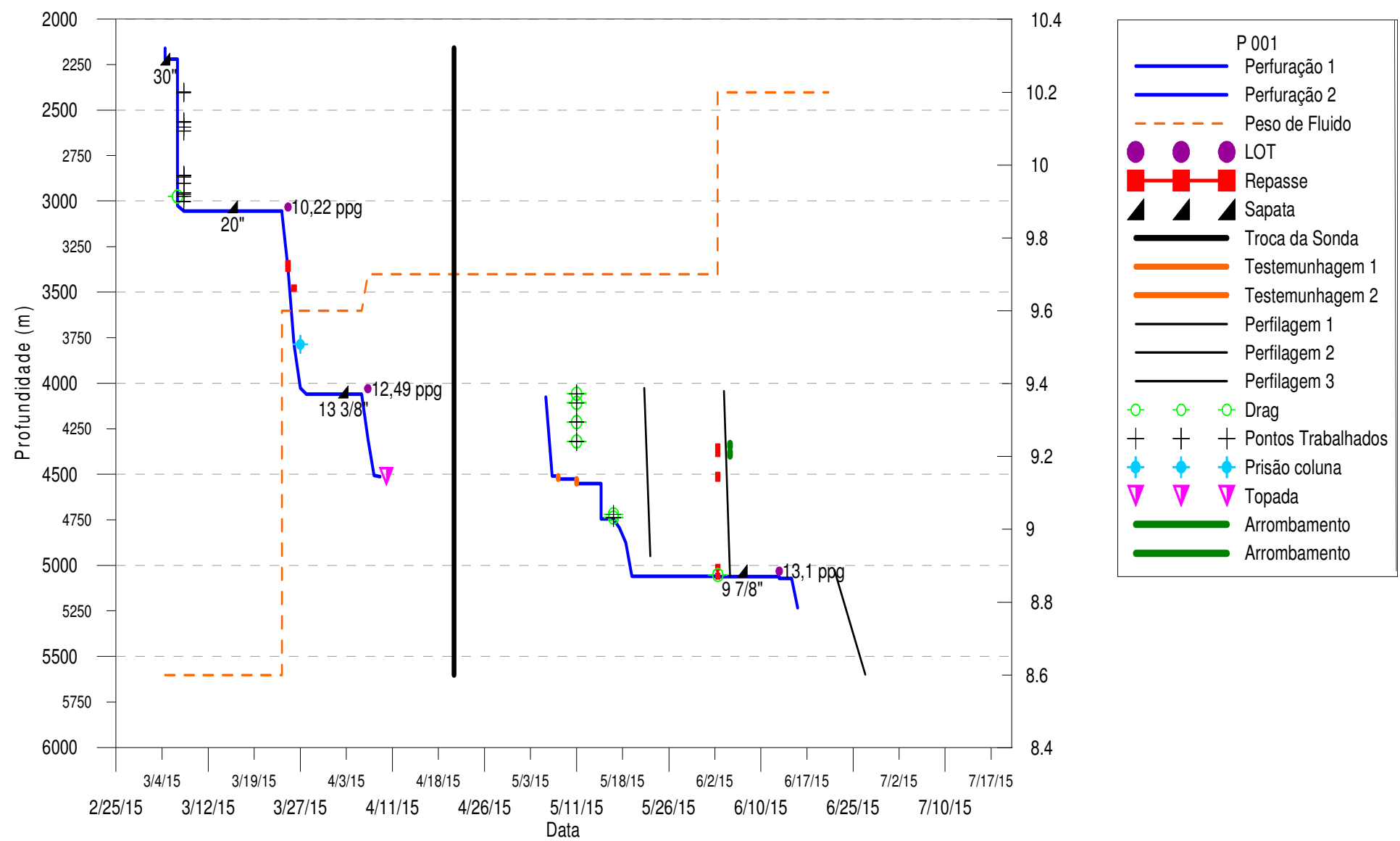

Figura 3.9 - Gráfico de Perfuração versus Tempo do poço P-001 (Relatório Técnico Parcial 4, 2017 - Projeto de Pesquisa e Desenvolvimento "Soluções em Folhelhos"). 


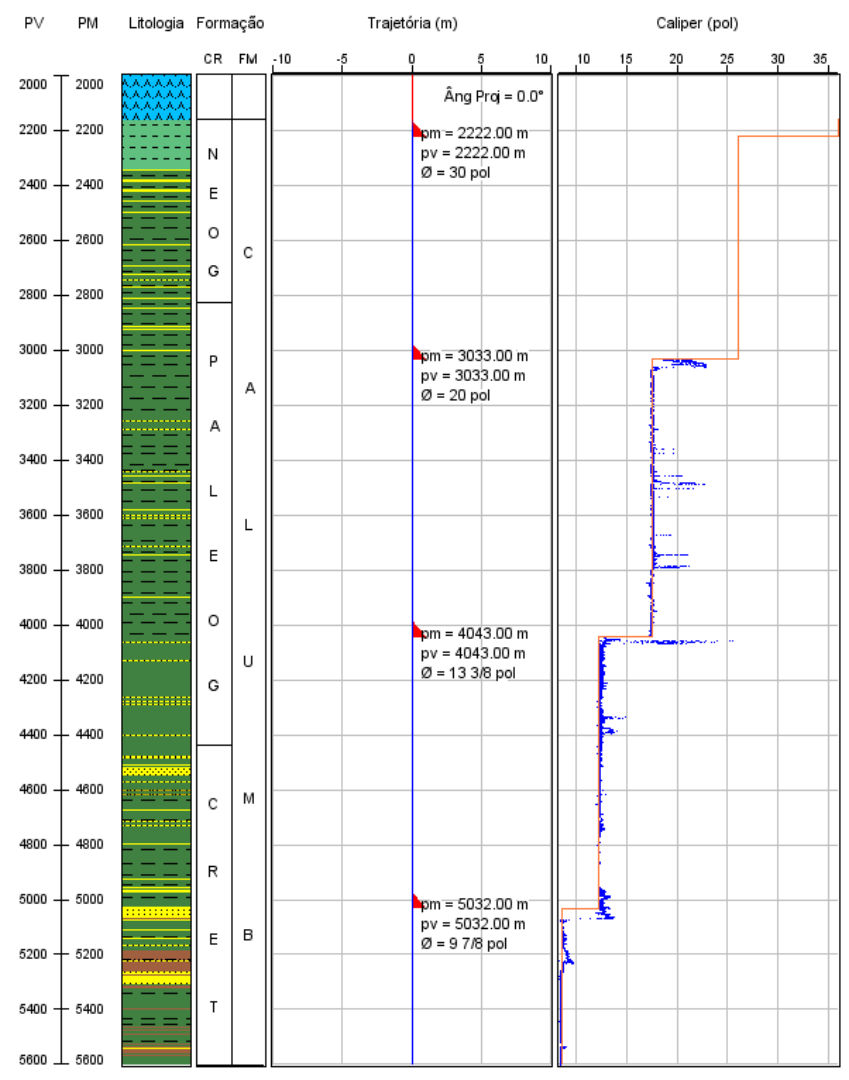

P.001

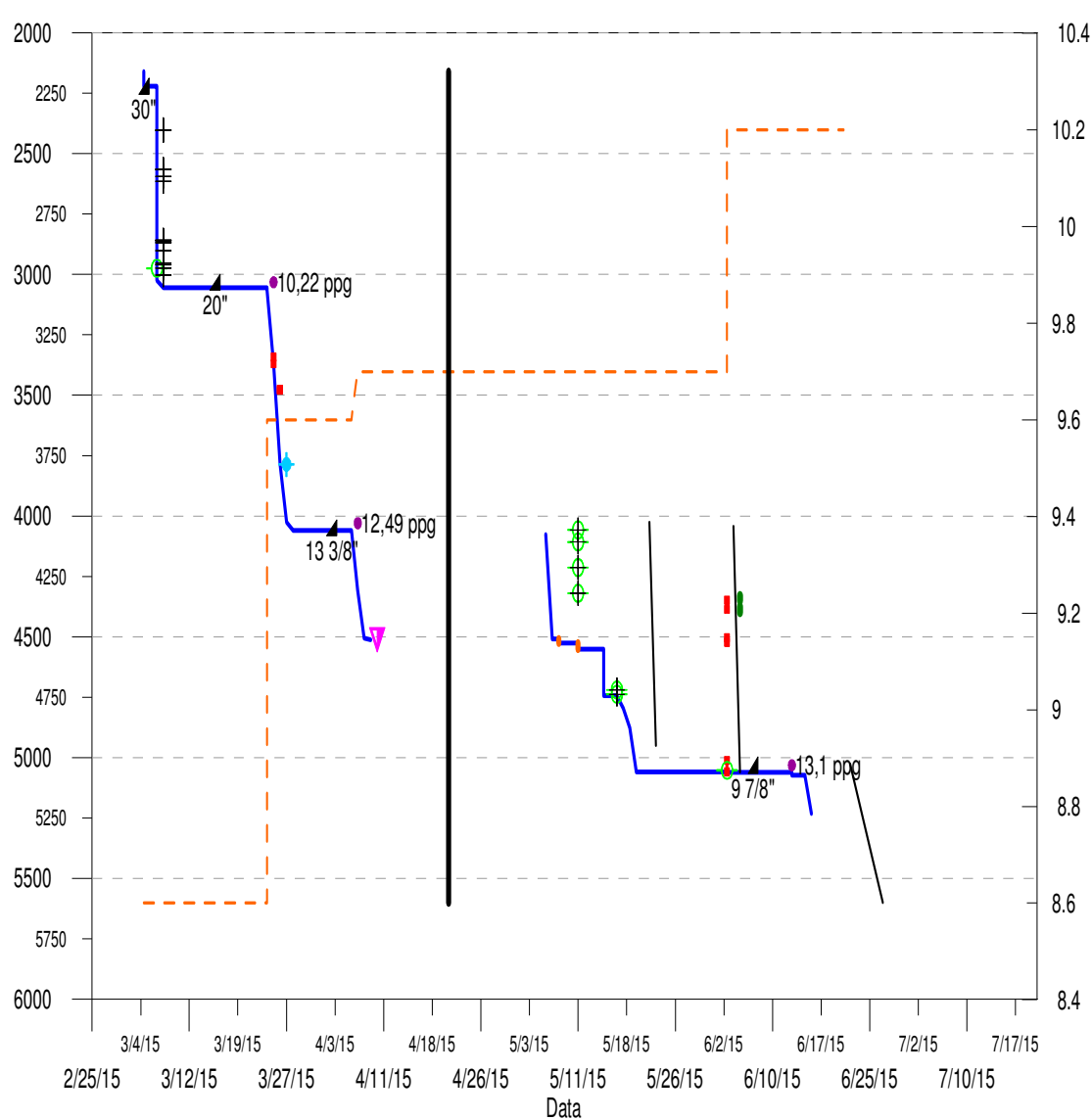

Figura 3.10 - Correlação da litologia, Trajetória, Perfil Caliper e Gráfico de Profundidade versus Tempo do poço P-001 (Relatório Técnico Parcial 4, 2017 - Projeto de Pesquisa e Desenvolvimento "Soluções em Folhelhos"). 
Na Figura 3.12 está representada a janela de cálculo do módulo de perfis, na qual, da esquerda para direita está composta pela profundidade do poço, tanto vertical como medida, a coluna litológica, a trajetória e os perfis sintéticos de Caliper, Tempo de Trânsito (DTC e DTS), de Gamma Ray e Densidade.

Pode-se observar que as leituras dos perfis mencionados começam a partir da sapata da fase 20" a 3033m (cor azul), exceto o perfil de Gamma Ray que foi feita ao longo de toda extensão do poço. É provável que, por questões econômicas, não costume-se fazer a leitura dos perfis na primeira fase. No entanto, foi realizado um ajuste de curva para obter a tendência do perfil desde o fundo do mar (cor vermelha).

Ainda na Figura 3.12 nota-se o comportamento contínuo do perfil Gamma Ray nas formações argilosas e um comportamento perturbado devido às intercalações das formações, principalmente na zona reservatório. O perfil de densidade aumenta ao longo da profundidade como produto da sobreposição das camadas subjacentes e também apresenta comportamento perturbado na zona reservatório devido às intercalações das formações.

Finalmente, através do perfil Caliper é possível constatar arrombamentos não somente nos trechos relatados no BDP (4330m a 4350m e 4375m a 4400m), como também nos trechos entre $3033 \mathrm{~m}$ a $3060 \mathrm{~m}$ e $5100 \mathrm{~m}$ a $5300 \mathrm{~m}$ cuja ocorrência, em sua maioria, é constatada em formações de folhelho, evidenciando uma possível condição de instabilidade.

A Figura 3.13 apresenta os perfis calculados a partir dos perfis de entrada. Observa-se através do perfil de densidade dos grãos que a coluna litológica em sua maioria é composta por folhelho uma vez que o valor de $2,75 \mathrm{~g} / \mathrm{cm}^{3}$ é apresentado de forma quase constante ao longo do poço. Os valores inferiores a $2,75 \mathrm{~g} / \mathrm{cm}^{3}$ correspondem às litologias intercaladas como arenito, principalmente.

No perfil de volume de argila, o comportamento é similar. Observa-se um volume de argila quase constante nas formações impermeáveis como folhelho e nos trechos de reservatório, principalmente, uma diminuição considerável do volume de argila devido às formações permeáveis, como o arenito.

Já no perfil de porosidade, nota-se um comportamento de um processo de compactação normal uma vez que a porosidade diminui ao longo da profundidade.

O cálculo do gradiente de sobrecarga no módulo de sobrecarga do SEST foi estimado através do perfil de densidade disponível. Já o gradiente de pressão de poros foi gerado através dos dados de pressão de poros Post Mortem disponibilizados pelo Centro de Pesquisa da PETROBRAS (CENPES). 
No módulo de propriedades mecânicas foi considerado como dado de entrada um ângulo de atrito fixo de $30^{\circ}$ para todas as rochas perfuradas, um coeficiente de Biot igual a 1, considerando a teoria da elasticidade e a coesão conforme Equação (3.12). As Figuras 3.14 e 3.15 apresentam os perfis das propriedades mecânica das rochas perfuradas.

No módulo de tensões in situ, obteve-se a estimativa das tensões horizontais considerando, a partir da teoria da elasticidade, a bacia como relaxada. O cálculo foi realizado em função da tensão de sobrecarga e dados de LOT relatado no BDP nas profundidades $3033 \mathrm{~m}$, 4030m e $5032 \mathrm{~m}$. Plotou-se o gráfico de LOT versus sobrecarga e traçou-se a linha de tendência que forneceu o melhor coeficiente de correlação (Figura 3.11). Esta relação estimou a curva da tensão horizontal mínima ao longo de todo o poço, definida como o limite superior da janela operacional.

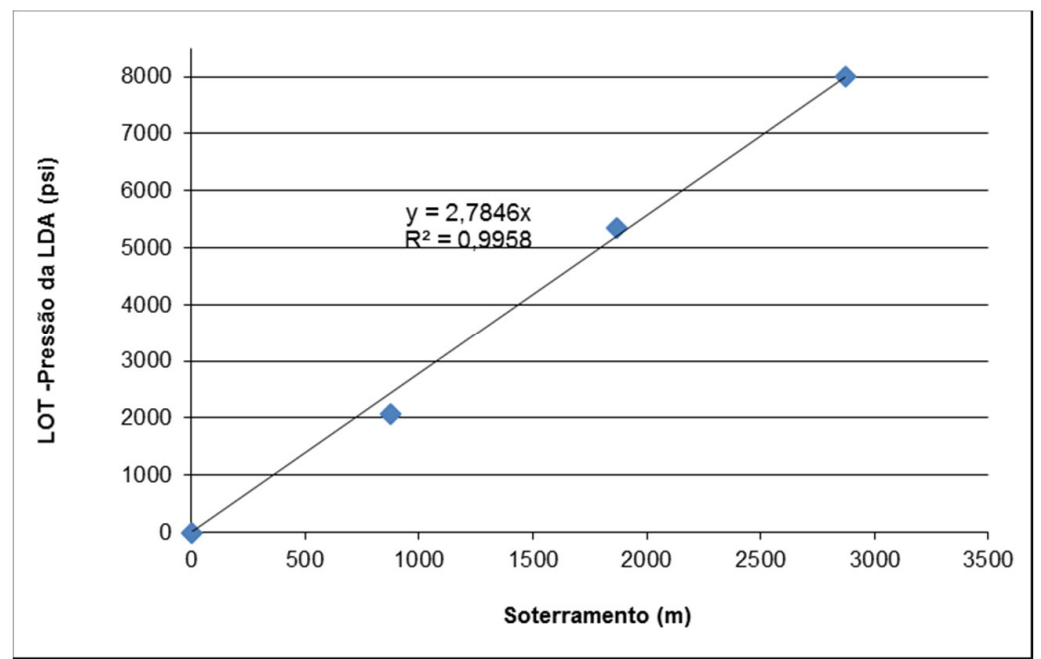

Figura 3.11 - Estimativa do coeficiente de correlação através da regressão linear.

Por último, no módulo de gradientes, foi adotado o critério de ruptura de Mohr-Coulomb e determinou-se os gradientes de colapso inferior, colapso superior, fratura os quais, em conjunto com os gradientes de sobrecarga, pressão de poros e as tensões in situ determinadas nos módulos anteriores e o peso de fluido de perfuração utilizado no poço P-001 geraram a janela operacional da Figura 3.16.

Foram plotados também, na Figura 3.16 todos os eventos de perfuração levantados do BDP, os quais podem ser correlacionados com a trajetória, litologia e perfil Caliper do poço. 
PUC-Rio - Certificação Digital No 1521452/CA

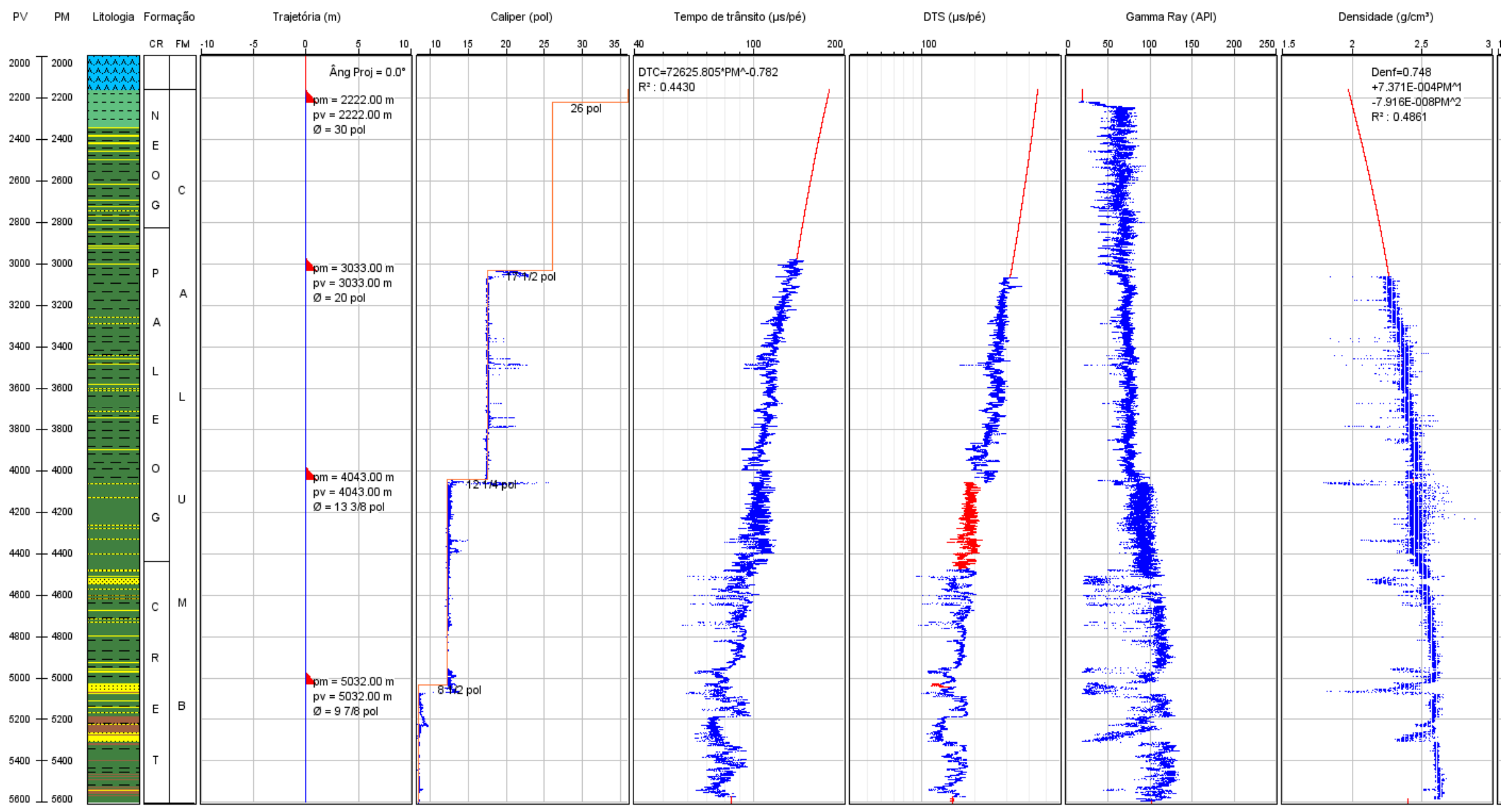

Figura 3.12 - Módulo de Perfis - Perfis de entrada do poço P-001 (Relatório Técnico Parcial 4, 2017 - Projeto de Pesquisa e Desenvolvimento "Soluções em Folhelhos"). 


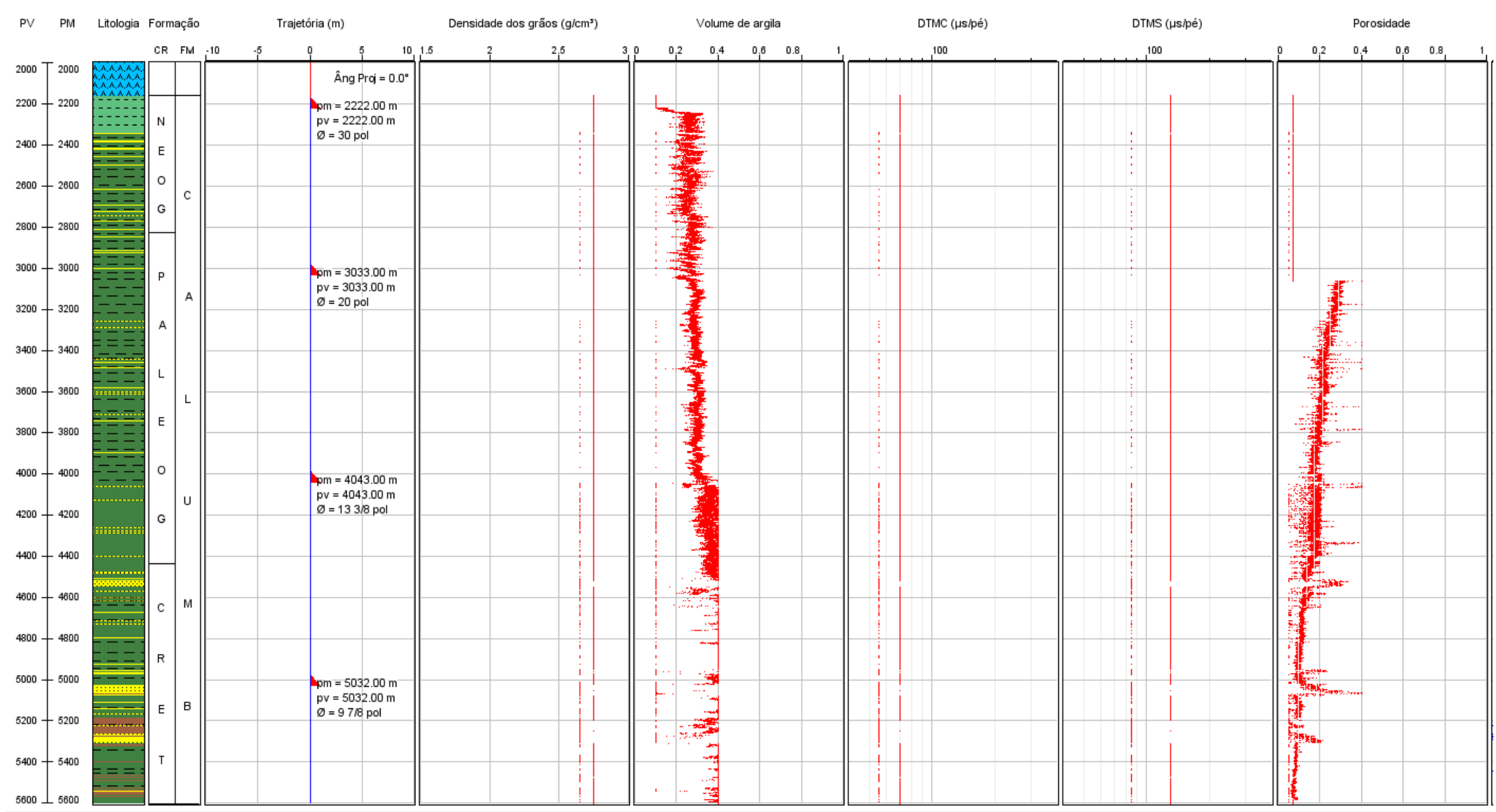

Figura 3.13 - Módulo de Perfis - Perfis calculados pelo SEST (Relatório Técnico Parcial 4, 2017 - Projeto de Pesquisa e Desenvolvimento "Soluções em Folhelhos"). 


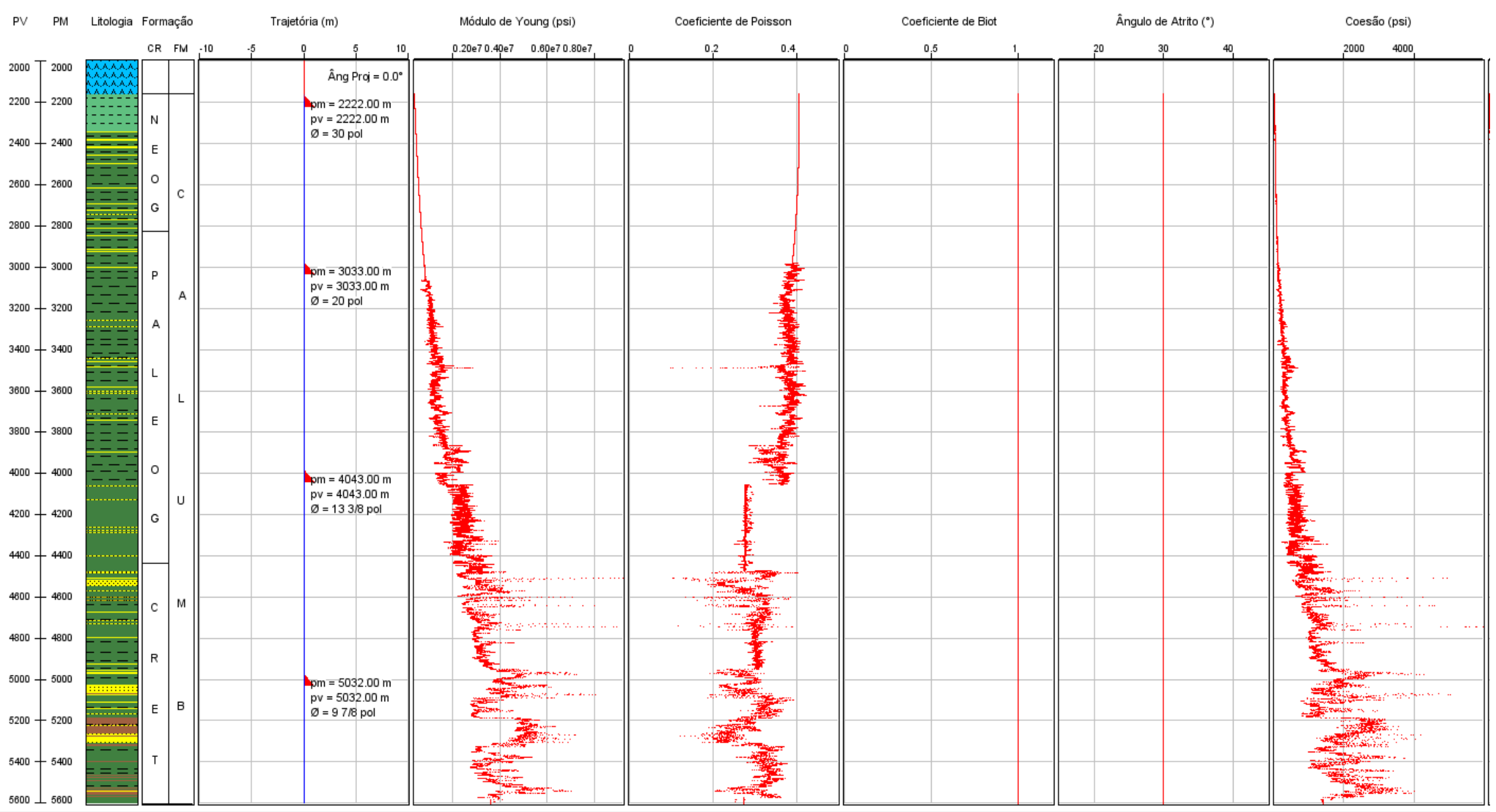

Figura 3.14 - Propriedades Mecânicas do poço P-001 (Relatório Técnico Parcial 4, 2017 - Projeto de Pesquisa e Desenvolvimento "Soluções em Folhelhos"). 


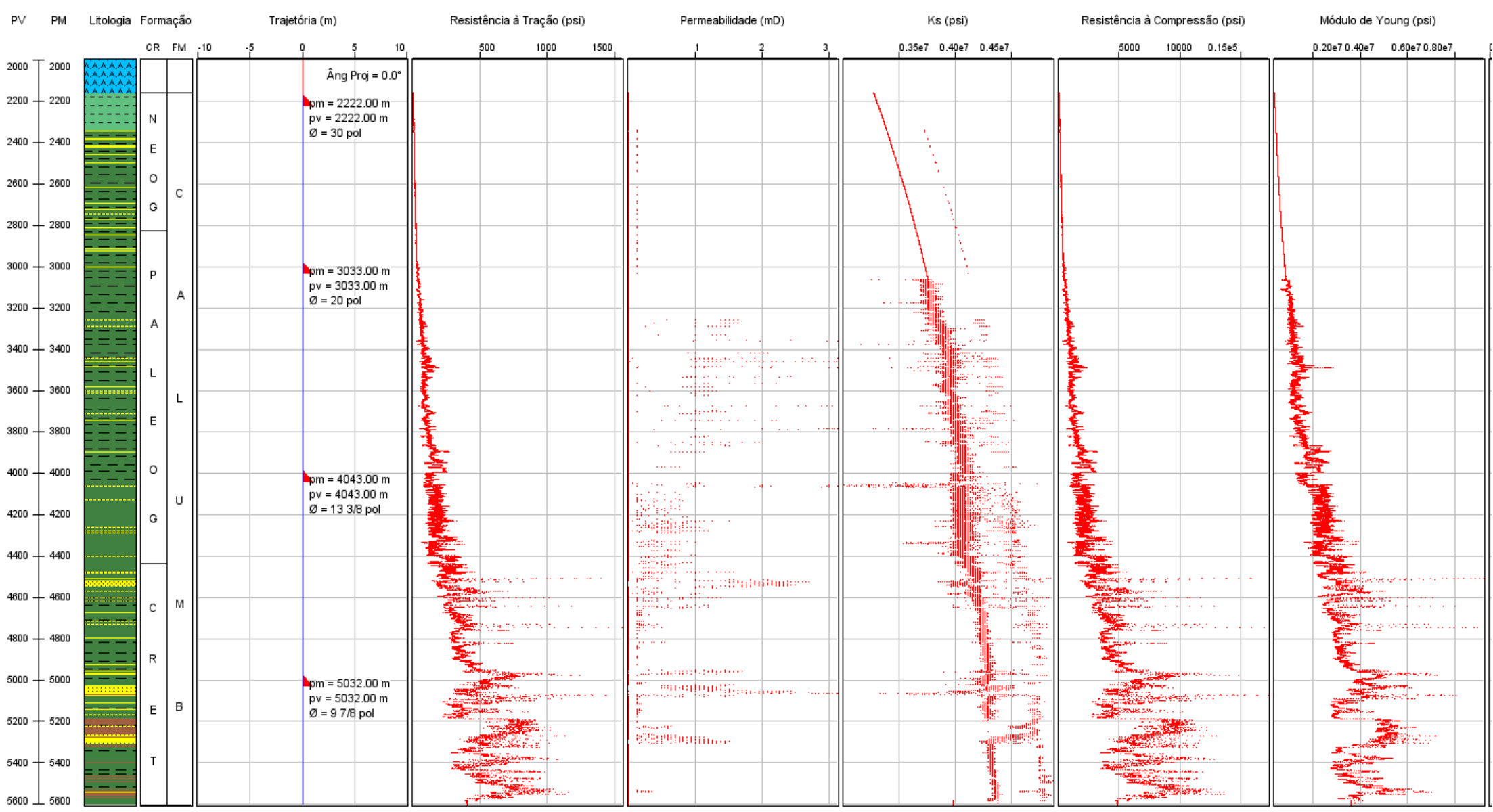

Figura 3.15 - Continuação das Propriedades Mecânicas do poço P-001 (Relatório Técnico Parcial 4, 2017 - Projeto de Pesquisa e Desenvolvimento "Soluções em Folhelhos"). 


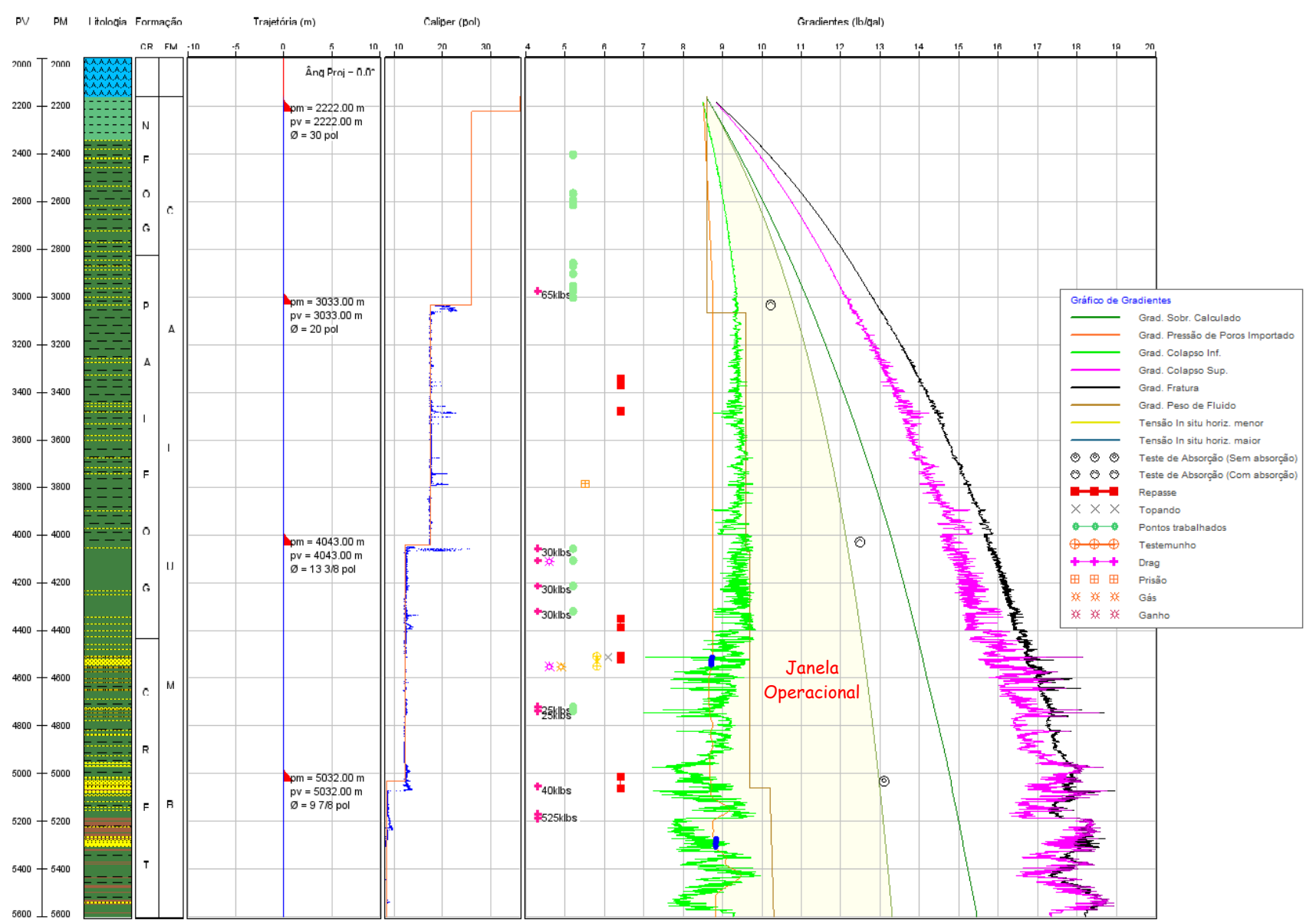

Figura 3.16 - Módulo de Gradientes - Janela Operacional do poço P-001 (Relatório Técnico Parcial 4, 2017 - Projeto de Pesquisa e Desenvolvimento "Soluções em Folhelhos"). 
A retroanálise do poço P-001 permitiu observar que a janela operacional do poço usando um fluido de perfuração sintético não penetrante é delimitada entre o colapso inferior e a tensão horizontal e que a densidade do fluido de perfuração se manteve próximo ao gradiente de colapso inferior, mas não menor. Portanto, os arrombamentos constatados que caracterizam a instabilidade do poço não foram de origem mecânica, excluindo a hipótese de que os fluidos de perfuração com peso insuficiente são os agentes causadores do problema.

Finalmente, através de todo o estudo feito correlacionando os arrombamentos à litologia, profundidade, eventos de perfuração relatados no BDP e análise de estabilidade, com base na relação de problemas e causas descrita por Rabelo (2008), algumas hipóteses de causas para o arrombamento constatado podem ser levantadas, como:

1- Perfuração através de folhelho frágil: indução de fragmentação através da vibração das colunas de perfuração.

2- Reatividade da formação ao fluido de perfuração: apesar do fluido utilizado ser um fluido sintético não penetrante (base óleo), a qualidade do fluido pode ter sido ineficiente, possibilitando a interação físico-química entre a formação.

\section{4 Considerações Finais}

Com o intuito de identificar os problemas de instabilidade do poço e seu possível agente causador, foi realizada uma retroanálise do poço P-001 através dos dados de perfuração, como Boletim Diário de Perfuração e Dados de Perfil, e da análise de estabilidade do poço,

Após as análises do BDP e dados de perfis, os principais problemas constatados foram arrombamentos nas fases 20 ", 13 3/8" e $97 / 8$ ".

A identificação dos agentes causadores dos problemas de instabilidade desta dissertação foi baseada nas descrições de Rabelo (2008) e Tavares (2006) que correlacionam os problemas a indícios e causas. Esta correlação é descrita brevemente no Capítulo 2 desta dissertação.

A análise de estabilidade gerada pelo software SEST, permitiu identificar que os agentes causadores do problema de instabilidade não foram de origem mecânica, uma vez que o peso de fluido estava dentro dos limites estabelecidos pela janela operacional, excluindo, portanto, a hipótese de que os fluidos de perfuração com peso insuficiente são os agentes causadores do problema. 
Identificação dos Problemas de Instabilidade do

Poço

Finalmente, conclui-se que a geração dos arrombamentos tem como possíveis agentes causadores: a ação mecânica da coluna de perfuração ou a reatividade da formação ao fluido de perfuração utilizado.

Finda a retroanálise de estabilidade do poço e com intuito de proporcionar um melhor desempenho econômico para futuras operações em poços correlacionados, esta dissertação propõe a realização de uma análise de estabilidade considerando os efeitos físico-químicos quando amostras de folhelhos do poço são submetidos a fluidos salinos hipotéticos a fim de simular fluidos base água. 


\section{4 \\ Análise de Testemunho em Laboratório}

\section{1}

\section{Introdução}

A seleção e a utilização de um fluido de perfuração adequado tem um importante papel técnico e econômico na perfuração de um poço. Finda a retroanálise de estabilidade do poço em estudo P-001 e com intuito de proporcionar um melhor desempenho econômico para futuras operações em poços correlacionados, o objetivo deste capitulo é obter os parâmetros de transporte de massa que influenciam no comportamento dos folhelhos expostos a diferentes soluções salinas a fim de simular os fluidos de perfuração à base de água.

Estes estudos foram realizados na célula de difusão, cujo equipamento é capaz de simular as condições de pressão no campo e avaliar aspectos físicoquímicos da interação folhelho-fluido, assim como determinar experimentalmente os parâmetros de transporte de massa (água e íons) devido aos gradientes hidráulicos e químicos. Os parâmetros de transporte obtidos do ensaio, necessários para a análise de estabilidade de poço considerando os efeitos físicoquímicos, foram: a eficiência de membrana ou coeficiente de reflexão ( $\Re$ ) e a permeabilidade absoluta do folhelho.

Quatro amostras de folhelho de diferentes profundidades do poço P-001 foram estudadas. No laboratório, para uma melhor identificação, as amostras de folhelho são nomeadas conforme Tabela 4.1. Durante a fase de difusão, os corpos de prova destes folhelhos foram submetidos a três fluidos de solução salina com diferentes concentrações químicas, conforme descrito na Tabela 4.2.

Uma campanha de caracterização foi realizada nas quatro amostras, com a finalidade de compreender, a partir das características estruturais, os processos de transferência de massa. 
Tabela 4.1 - Amostras de testemunho do poço P-001 e suas respectivas profundidades.

\begin{tabular}{cc}
\hline Amostra & Profundidade $(\mathrm{m})$ \\
\hline CP-A & 5048 \\
CP-B & 5135 \\
CP-C & 5193 \\
CP-D & 5336 \\
\hline
\end{tabular}

Tabela 4.2 - Composição química dos fluidos de solução salina em estudo.

\begin{tabular}{cc}
\hline Fluido & Composição \\
\hline Fluido 01 & $100 \mathrm{~g} / \mathrm{L} \mathrm{NaCl}+$ Goma Xantana + Água \\
\hline Fluido 02 & $200 \mathrm{~g} / \mathrm{L} \mathrm{NaCl}+$ Goma Xantana + Água \\
\hline Fluido 03 & Água do Mar \\
\hline
\end{tabular}

\section{2}

Caracterização do Folhelho

A caracterização de folhelhos tem como objetivo auxiliar na previsão de instabilidades geradas pelas interações entre os fluidos de perfuração e a formação argilosa, que podem ocorrer quando operações de perfuração de poços de petróleo atravessam pacotes destas rochas (Rabe et al.,2003).

Uma campanha de caracterização foi realizada nas quatro amostras de folhelho de diferentes profundidades, proveniente de um mesmo poço (Tabela 4.1), com a finalidade de compreender, a partir das características estruturais, os processos de transferência de massa.

A caracterização dos folhelhos foi realizada através dos seguintes ensaios laboratoriais: análise granulométrica, análise química e ensaios de porosimetria por injeção de mercúrio, os quais são descritos nessa seção, bem como os resultados gerados para cada amostra de folhelho.

\subsubsection{Análise Granulométrica}

A análise granulométrica quantifica e classifica os constituintes individuais dos folhelhos. Com este objetivo, foram realizadas análises granulométricas utilizando a técnica a laser em modo dispersão líquida, que garante maior precisão nas medições. O equipamento utilizado foi o analisador de tamanho de partículas a laser da marca Cilas modelo 1190 do Laboratório de Geotecnia do departamento de Engenharia Civil da PUC-Rio (Figura 4.1). 
Para realização do ensaio, foram necessários 10 gramas de cada amostra de folhelho, limpa, pulverizada (utilizando uma mão de gral em almofariz de porcelana) e peneiradas empregando uma peneira ASTM 40mesh.

As curvas granulométricas obtidas são apresentadas na Figura 4.2, Figura 4.3, Figura 4.4 e Figura 4.5, para as amostras de CP-A, CP-B, CP-C e CP-D, respectivamente. Observa-se que as amostras de folhelho se comportam de maneira bem similar.

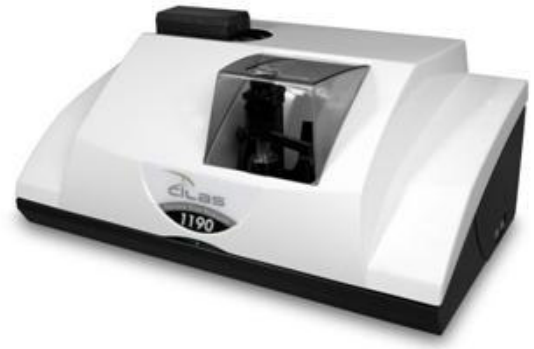

Figura 4.1 - Analisador de tamanho de partículas a laser da marca Cilas.

A Tabela 4.3 apresenta uma comparação dos diâmetros médios e a sua constituição em porcentagem dos corpos de prova dos folhelhos. Já a Tabela 4.4 apresenta a classificação das amostras quanto à distribuição de tamanho de grãos de acordo com a escala descrita pela ABNT (NBR6502/95). Observa-se que as amostras apresentam uma distribuição uniforme com alta porcentagem de material de fração silte e porcentagens consideravelmente menores de material fração argila e areia.

Segundo a classificação proposta por Shepard (1954), baseada nos conteúdos percentuais de areia, silte e argila, as amostras de CP-A, CP-B, CP-C e CP-D seriam denominadas folhelhos siltosos.

Tabela 4.3 - Tabela comparativa dos resultados dos ensaios de granulometria.

\begin{tabular}{ccccc}
\hline Comparação & $\begin{array}{c}\text { CP-A Média } \\
(\boldsymbol{\mu} \mathbf{m})\end{array}$ & $\begin{array}{c}\text { CP-B Média } \\
(\boldsymbol{\mu m})\end{array}$ & $\begin{array}{c}\text { CP-C Média } \\
(\boldsymbol{\mu m})\end{array}$ & $\begin{array}{c}\text { CP-D Média } \\
(\boldsymbol{\mu m})\end{array}$ \\
\hline Diâmetro a 10\% & 2,92 & 2,59 & 3,12 & 2,48 \\
Diâmetro a 50\% & 18,99 & 17,74 & 20,43 & 15,73 \\
Diâmetro a 90\% & 59,28 & 53,29 & 57,59 & 56,66 \\
Diâmetro médio & 26,09 & 23,84 & 26,37 & 23,54 \\
\hline
\end{tabular}

Tabela 4.4 - Classificação das amostras quanto a distribuição de tamanho de grãos.

\begin{tabular}{ccccc}
\hline Comparação & $\begin{array}{c}\text { CP-A } \\
\text { Média (\%) }\end{array}$ & $\begin{array}{c}\text { CP-B } \\
\text { Média (\%) }\end{array}$ & $\begin{array}{c}\text { CP-C } \\
\text { Média (\%) }\end{array}$ & $\begin{array}{c}\text { CP-D } \\
\text { Média (\%) }\end{array}$ \\
\hline Argila $(<0,002 \mathrm{~mm}$ ) & 6,17 & 7,15 & 5,69 & 7,56 \\
Silte (entre 0,06 e 0,002 mm) & 84,34 & 86,92 & 85,85 & 84,19 \\
Areia fina (entre 2,0 e 0,06 mm) & 9,49 & 5,93 & 8,46 & 8,25 \\
\hline
\end{tabular}




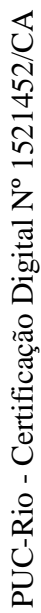

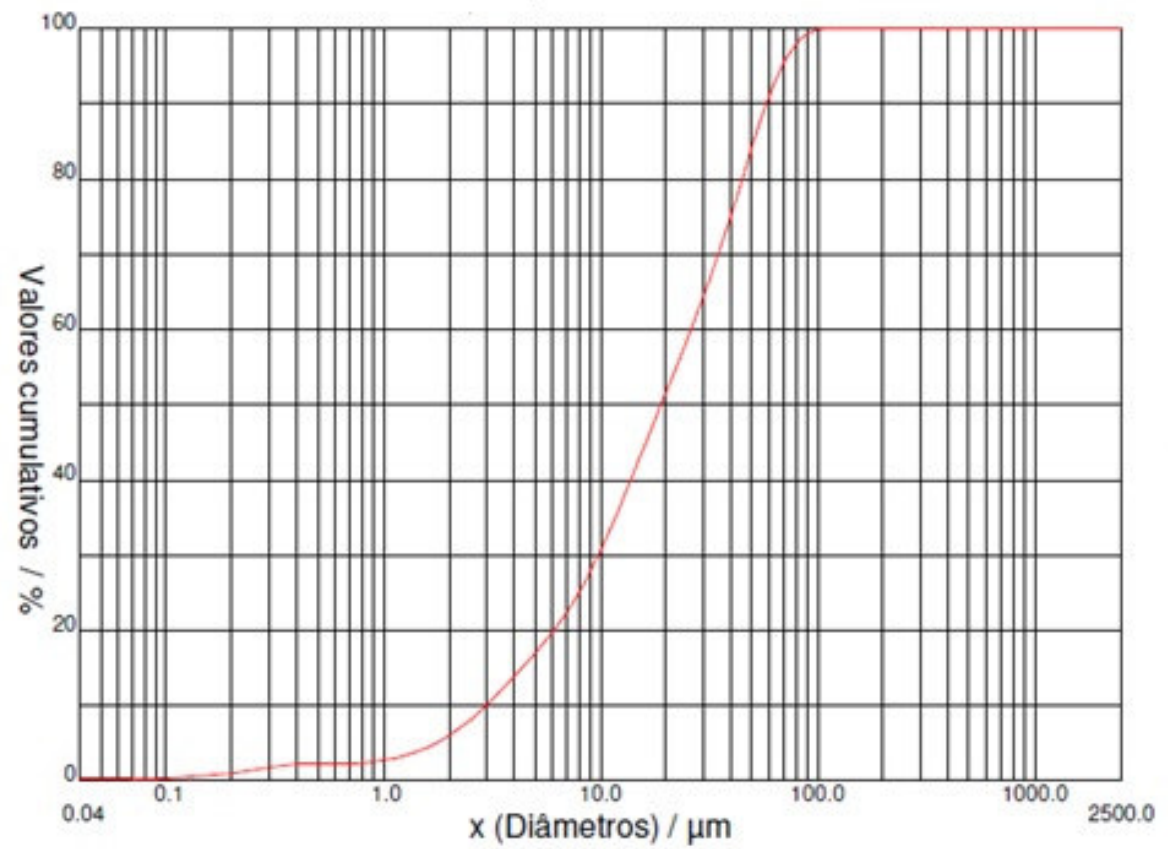

Figura 4.2 - Distribuição granulométrica do CP-A.

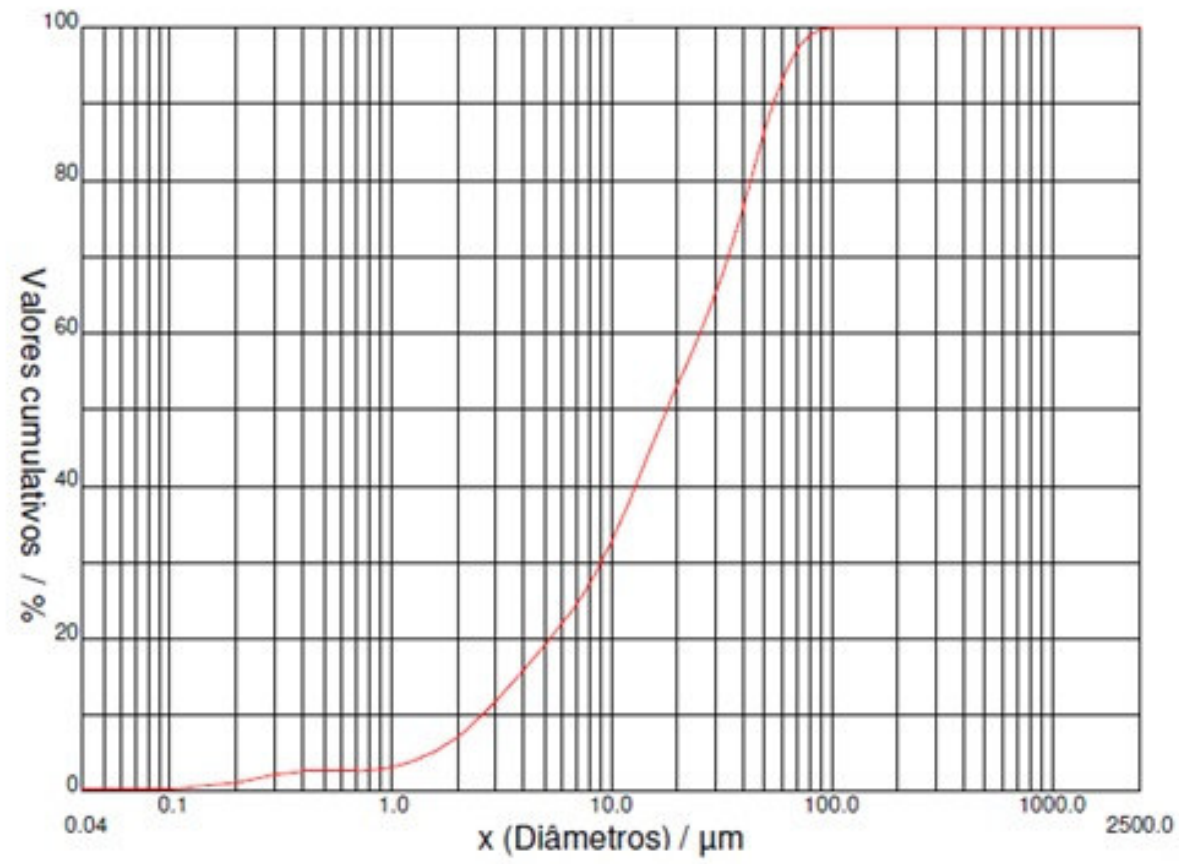

Figura 4.3 - Distribuição granulométrica do CP-B. 


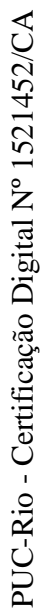

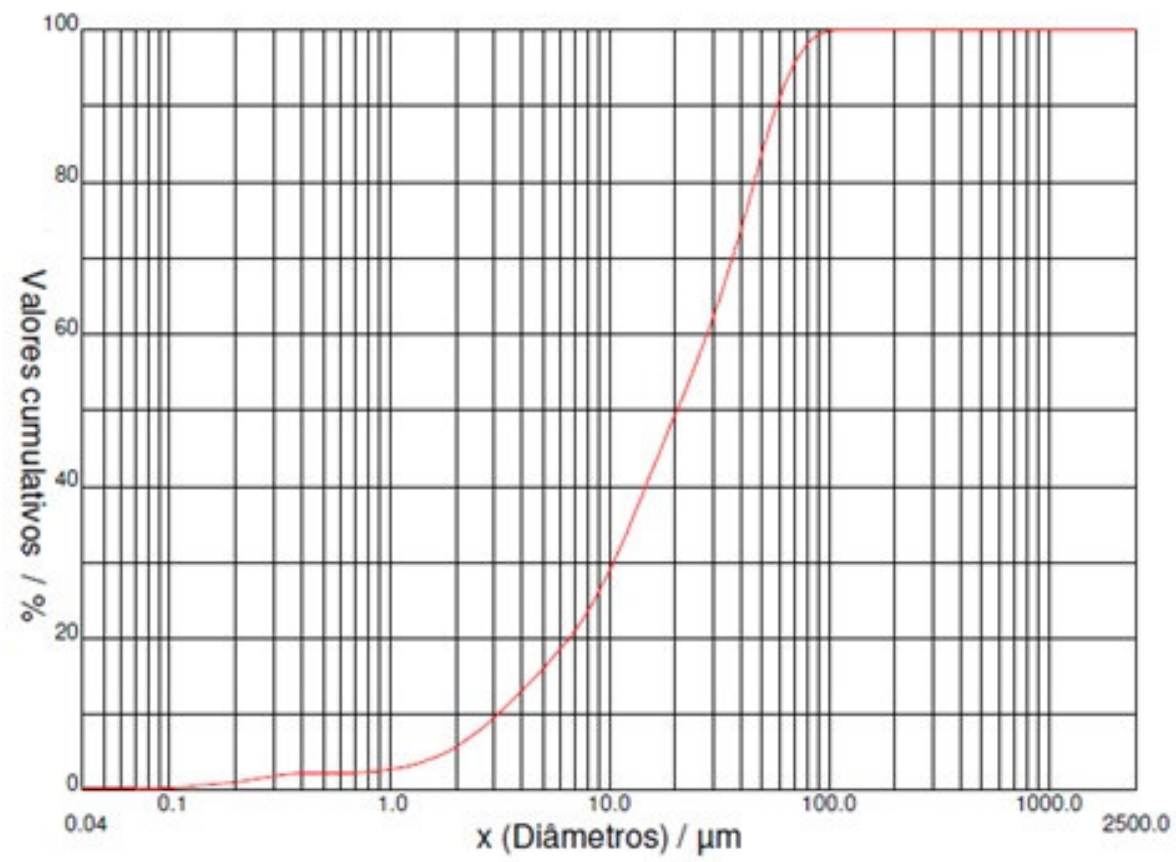

Figura 4.4 - Distribuição granulométrica do CP-C.

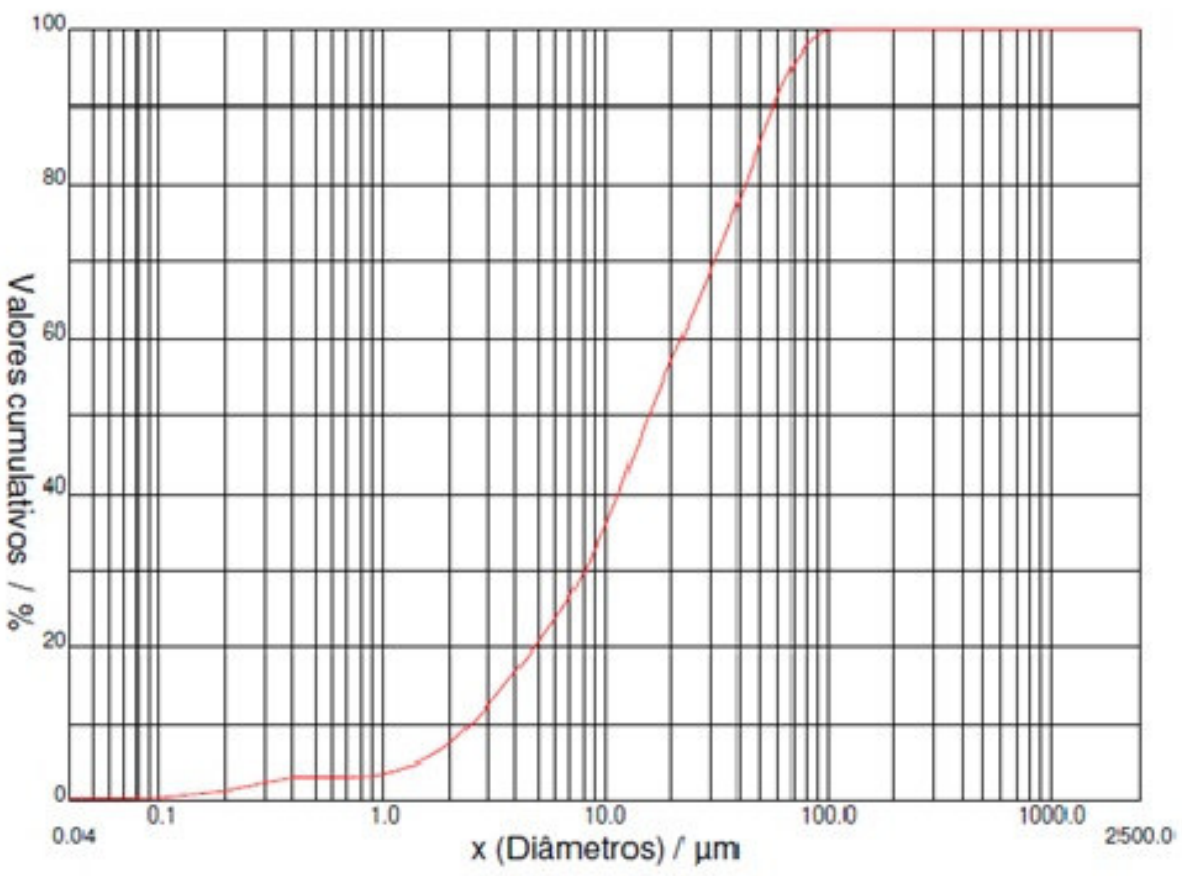

Figura 4.5 - Distribuição granulométrica do CP-D. 


\subsubsection{Composição Química}

A avaliação da composição química dos constituintes dos folhelhos em estudo foi realizada por meio de análises químicas utilizando a técnica de Fluorescência de Raios-X.

\subsubsection{Análise Química}

A fim de quantificar os óxidos que compõem as amostras, as análises químicas realizadas utilizaram a técnica de Fluorescência de Raios-X. O equipamento utilizado foi um analisador de fluorescência de raios- $X$ de energia dispersiva da marca Shimadzu modelo EDX-700 do departamento de Engenharia Química da PUC-Rio (Figura 4.6)

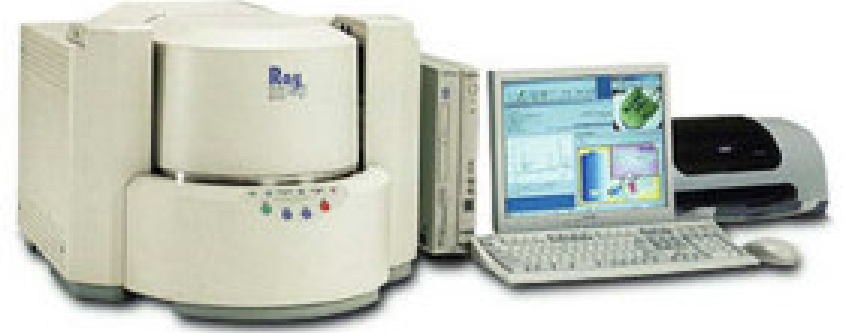

Figura 4.6 - Analisador de fluorescência de raio-x de energia dispersiva marca Shimadzu.

A preparação das amostras seguiu os mesmos procedimentos das amostras utilizadas no ensaio de distribuição granulométrica, ou seja, as amostras foram limpas, pulverizadas e peneiradas (peneira 40mesh).

A Tabela 4.5 apresenta os resultados das análises químicas dos folhelhos estudados nesta dissertação.

Tabela 4.5 - Análises químicas dos constituintes dos folhelhos.

\begin{tabular}{ccccc} 
Óxidos & CP-A (\%) & CP-B (\%) & CP-C (\%) & CP-D (\%) \\
\hline SiO2 & 56,09 & 55,25 & 59,49 & 54,04 \\
Al2O3 & 31,42 & 32,9 & 31,49 & 34,28 \\
\hline Fe2O3 & 4,37 & 4,81 & 3,65 & 4,86 \\
\hline K2O & 4,07 & 3,78 & 3,46 & 3,99 \\
CaO & 2,66 & 1,94 & 0,58 & 1,12 \\
\hline TiO2 & 0,72 & 0,74 & 0,77 & 0,78 \\
\hline SO3 & 0,53 & 0,41 & 0,44 & 0,79 \\
\hline TraçOS & 0,18 & 0,16 & 0,12 & 0,14 \\
\hline
\end{tabular}


Verifica-se que as quatro amostras de folhelhos apresentam maior proporção de óxidos de silício (SiO2) e alumínio (Al2O3), indicando a existência de quartzo e de argilominerais. Os argilominerais estão presentes normalmente nos estratos sedimentares rochosos (folhelhos e argilitos). O teor de óxido de cálcio $(\mathrm{CaO})$ indica a presença de calcita e a sua maior fração no folhelho $A$, quando comparado com os demais folhelhos, podem ser indícios da presença de microfósseis marinhos.

A presença de óxido de potássio (K2O) pode ser devido a presença de micas. Por outro lado, a presença de óxido de ferro (Fe2O3) pode indicar a possível presença de pirita e clorita em ambos os folhelhos.

Baixas porcentagens de óxido de titânio (TiO2) são verificadas nas amostras de folhelhos. Segundo Santos (1975), a presença de óxido de titânio ocorre em quase todas as argilas sedimentares, tendo como os minerais acessórios mais comuns rutilo, ilmenita ou anastásio. Portanto, segundo os resultados obtidos, seria possível conter um desses minerais acessórios na estrutura de ambos os folhelhos.

Verifica-se ainda que não foi reportada a presença de óxido de sódio (Na2O) e isto ocorre devido à sensibilidade do equipamento. Portanto, existe a possibilidade de conter este elemento formando parte da esmectita (montmorilonita) nas amostras.

\subsubsection{Porosimetria por Injeção de Mercúrio}

O estudo dos espaços vazios é de suma importância para compreender os processos de transporte de massa (íons e água) através dos folhelhos. Segundo Osuji et al. (2008), a maioria dos folhelhos exibe diâmetros dos poros maiores que os diâmetros dos íons hidratados; como consequência, os diâmetros dos poros têm um papel importante no ingresso de íons que diminui o fluxo osmótico em favor da estabilidade.

Neste contexto, a descrição dos espaços vazios (poros) dos folhelhos foi feita através de uma campanha de ensaios de porosimetria por injeção de mercúrio e o equipamento utilizado foi o porosímetro Autopore IV pertencente ao Laboratório de Interação Rocha-Fluido (LIRF) do Grupo de Tecnologia e Engenharia de Petróleo (GTEP) do Departamento da Engenharia Civil da PUCRio. O ensaio consiste na aplicação de um gradiente de pressão para que o fluido não molhante (mercúrio) penetre nos poros do folhelho. 
O material utilizado para os ensaios foram amostras estruturadas de cada folhelho secas em estufa a $105^{\circ} \mathrm{C}$ por 24 horas de modo a retirar a água livre. A temperatura adotada visou garantir a integridade dos argilominerais e prevenir possíveis trincamentos que mascarem o resultado.

A Figura 4.7 apresenta o gráfico de distribuição de raio de poros em termos de intrusão acumulativa de mercúrio para todas as amostras de folhelho. A partir deste gráfico é possível avaliar dois parâmetros importantes: a mediana dos raios dos poros em termos de volume (D50) e a porcentagem volumétrica de microporos. O primeiro representa o raio de poros correspondente a $50 \%$ do volume total de mercúrio intrudido e o segundo é caracterizado por possuir raios inferiores a $0,01 \mu \mathrm{m}$.

Observa-se que as curvas das amostras são similares, embora estas sejam de diferentes profundidades. As amostras são formadas por uma maior parcela de micro e mesoporos onde $90 \%$ de poros dos folhelhos possuem raio de poro inferior a 0,06 $\mu \mathrm{m}$, sendo um total de, aproximadamente, $70 \%$ de microporos nos CP-A, CP-B e CP-D e um total de $49 \%$ microporos no CP-C. Na avaliação mediana de raio dos poros as amostras tem raio de poro mediano no valor de $0,008 \mu \mathrm{m}$, exceto

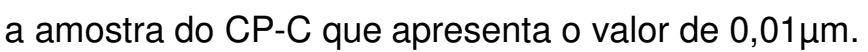

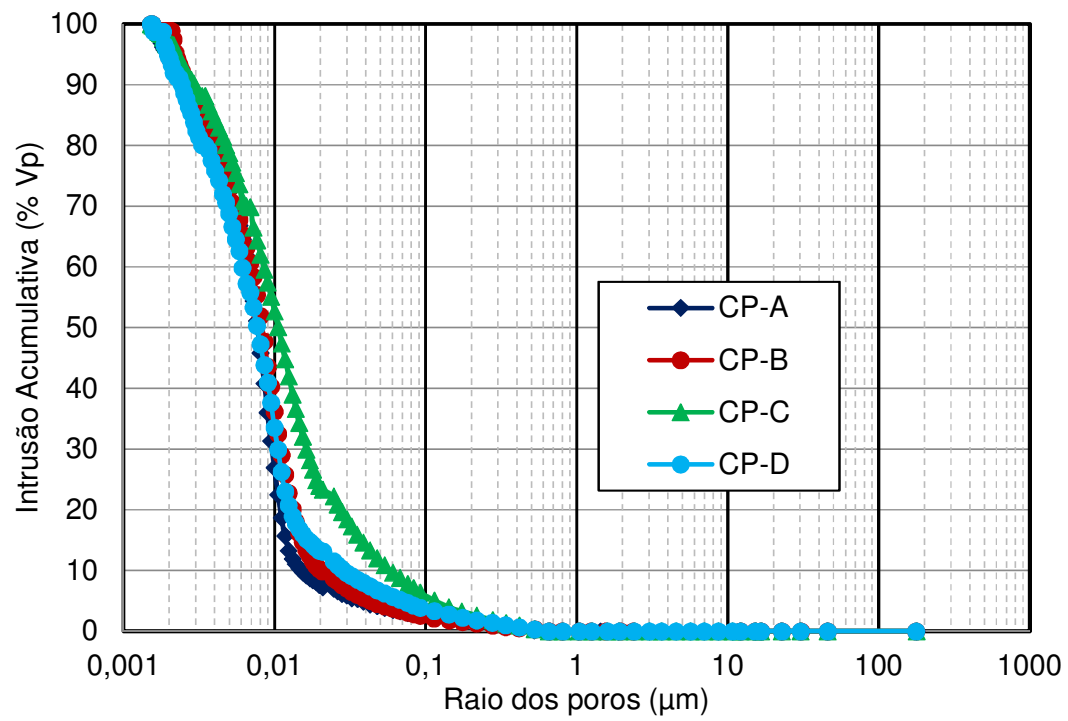

Figura 4.7 - Intrusão Acumulativa de mercúrio do CP-A, CP-B, CP-C e CP-D (Relatório Técnico, 2018 - Projeto de Pesquisa e Desenvolvimento "Soluções em Folhelhos").

A Figura 4.8 apresenta a distribuição de raio dos poros em função da intrusão incremental dos folhelhos. Verifica-se que as amostras de folhelho possuem uma distribuição uni-modal com o pico predominante entre 0,007 $\mu \mathrm{m}$ e 0,01 $\mu \mathrm{m}$. Pode-se inferir que os CP-A, CP-B, CP-C e CP-D apresentam, 
respectivamente, $5,26 \%, 4,20 \%, 3,36 \%$ e $4,13 \%$ de poros com raio igual a 0,0076 , $0,008,0,007$ e $0,009 \mu \mathrm{m}$.

O ensaio de injeção de mercúrio permite, também, obter a porosidade interconectada representada pelo somatório das áreas dos poros interconectáveis dos folhelhos. Desta forma, medem-se apenas os poros que se interconectam, ou seja, os poros que são alcançados pelo mercúrio introduzido.

Para fins comparativos, a Tabela 4.6 apresenta o resumo de todos os parâmetros obtidos mediante os ensaios de porosimetria para as quatro amostras de folhelho estudadas. Como podem ser observados, os valores de porosidade e raio de poros não estiveram diretamente relacionados com a profundidade. O CPB apresentou maior porosidade interconectada e segundo essa característica, apresentaria a menor restrição de íons e água dentro de sua estrutura; como consequência, apresentaria o menor coeficiente de reflexão quando comparado às demais amostras.

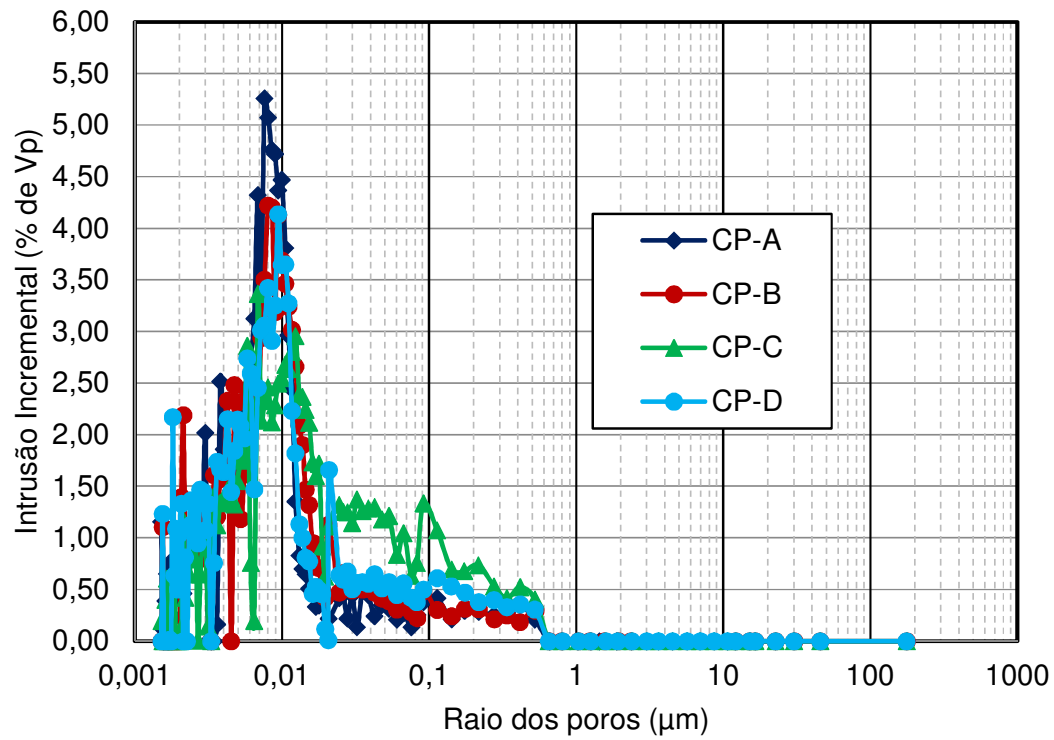

Figura 4.8 - Intrusão incremental dos CP-A, CP-B, CP-C e CP-D (Relatório Técnico 2018 - Projeto de Pesquisa e Desenvolvimento "Soluções em Folhelhos").

Tabela 4.6 - Parâmetros obtidos do ensaio de porosimetria por injeção de mercúrio.

\begin{tabular}{ccccc}
\hline Parâmetro & CP - A & CP - B & CP - C & CP - D \\
\hline $\begin{array}{c}\text { Raio de poro mediano } \\
(\mu \mathrm{m})\end{array}$ & 0,0080 & 0,0083 & 0,01 & 0,008 \\
$\begin{array}{c}\text { Massa específica } \\
\left(\mathrm{g} / \mathbf{c m}^{\mathbf{3}}\right)\end{array}$ & 2,55 & 2,59 & 2,53 & 2,57 \\
$\begin{array}{c}\text { Porosidade } \\
\text { interconectada (\%) }\end{array}$ & 6,38 & 6,53 & 5,85 & 5,72 \\
\hline
\end{tabular}




\section{3 \\ Ensaio na Célula de Difusão}

\subsubsection{Equipamento e Metodologia}

A célula de difusão (Figura 4.9) é um equipamento capaz de simular a interação físico-química entre folhelhos e os fluidos de perfuração através da aplicação de gradientes químicos e hidráulicos em um campo de tensões similares às condições in situ na qual a rocha é submetida. Mediante esta simulação, os parâmetros de transporte de massa como a permeabilidade e o coeficiente de reflexão (eficiência de membrana) são determinados.

Com o objetivo de obter tais parâmetros, a campanha experimental desta dissertação utilizou quatro células de difusão do Laboratório de Interação RochaFluido (LIRF) da PUC-Rio, desenvolvidas pelo GTEP (Grupo de Tecnologia e Engenharia de Petróleo). Diferente da célula de difusão desenvolvida por Muniz (2003), as quatro células de difusão utilizadas são projetadas unicamente para ensaios com aplicação de carregamento isotrópico por não possuírem célula de carga. A célula de difusão ensaia amostras de $38,1 \mathrm{~mm}$ de diâmetro e altura de $15 \mathrm{~mm}$ que podem ser submetidas à pressão confinante de até $21 \mathrm{MPa}$. Contudo, para a presente dissertação foram confeccionadas caps de $25,4 \mathrm{~mm}$ para trabalhos com amostras de folhelhos de 1 polegada. Na base da célula de difusão, encontram-se três canais que são destinados à medição de pressão de poros.

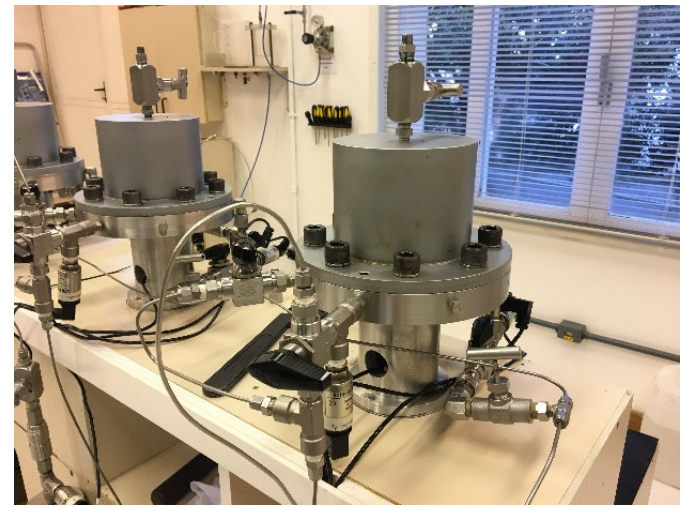

Figura 4.9 - Células de difusão do Laboratório de Interação Rocha-Fluido (LIRF).

O ensaio na célula de difusão é constituído por quatro fases ou etapas: saturação do corpo de prova, adensamento, transmissão de pressão e difusão de íons. Na descrição destas fases se incluem os conceitos básicos. O procedimento para realização dos ensaios foram os mesmos utilizados por Meléndez (2010). 


\subsubsection{Fase da Saturação}

A completa saturação ou um alto grau de saturação da amostra é de fundamental importância para uniformizar as propriedades medidas. Além do emprego do princípio das tensões efetivas, a saturação total permite obter medidas reais da variação de pressão de poros ao longo do ensaio.

O método de saturação por aplicação de contrapressão foi adotado nesta dissertação. A aplicação de acréscimos de pressão confinante é acompanhada por iguais acréscimos de contrapressão, de forma que a tensão efetiva seja constante, reduzindo a deformação do corpo de prova. Esta técnica, além de saturar o corpo de prova, dissolve bolhas de ar que possam existir entre a amostra e o geotêxtil e nas linhas de contrapressão.

Para verificar o grau de saturação do corpo de prova, utiliza-se o parâmetro B de Skempton (1954) dado pela Equação (4.1). Monitora-se o acréscimo de pressão de poros devido ao aumento da pressão de confinamento sob condições não drenadas. Os estágios de confinamento acontecem até o momento em que o valor do parâmetro $B$ se mostra próximo de 1 ou quando o valor se mantiver constante em dois estágios consecutivos.

$$
B=\frac{\Delta u}{\Delta \sigma_{\text {conf }}}
$$

Onde:

$\Delta u=$ variação da pressão de poros sob condições não drenadas

$\Delta \sigma_{\text {conf }}=$ variação da pressão confinante

\subsubsection{Fase de Adensamento}

Finalizada a saturação dos corpos de prova, inicia-se a fase de adensamento a fim de dissipar todo excesso de pressão de poros gerado devido ao carregamento imposto ao corpo de prova e de forma a garantir que não se tenha gradiente de pressão no mesmo.

A válvula de drenagem é aberta para o sistema de contrapressão, reduzindo o excesso de pressão de poros gradualmente até o valor da contrapressão aplicada. A dissipação de pressão de poros implica em redução de volume e aumento de tensão efetiva, que após ao adensamento, será igual à diferença entre a pressão confinante e a contrapressão aplicada (pressão na base e no topo do corpo de prova). 
$\mathrm{Na}$ fase de adensamento, os corpos de prova foram submetidos à pressão confinante de $12 \mathrm{MPa}$ e uma contrapressão de $5 \mathrm{MPa}$. Esta fase transcorreu por períodos de tempo não inferiores a 24 horas.

\subsubsection{Fase de Transmissão de Pressão}

Quando as pressões de poros e deformações do corpo de prova se estabilizam, ou seja, quando termina a fase de adensamento, inicia-se a fase de transmissão de pressão.

Esta fase consiste em aumentar a pressão no reservatório superior (topo do corpo de prova) e monitorar o crescimento de pressão no reservatório inferior (base do corpo de prova). Por possuir uma pressão na base inferior à pressão do topo, esta tende a se equilibrar, forçando o reservatório inferior a gradativamente aumentar sua pressão, pois a água sob pressão começa a migrar do topo para base. O tempo necessário para que a pressão na base atinja o valor da pressão do topo depende da permeabilidade e da compressibilidade do corpo de prova.

Nesta dissertação, adotou-se como pressão no reservatório superior (PP. Topo) o valor de 10MPa e como pressão no reservatório inferior (PP. Base) o valor de $5 \mathrm{MPa}$.

Nesta fase, pode-se avaliar o tempo que o corpo de prova necessita para uma total transmissão de pressão devido a um gradiente de pressão hidráulica imposto no topo e na base do corpo de prova. Em outras palavras, levando às condições de poço, pode-se simular o tempo para que a pressão hidráulica gerada pelo fluido de perfuração seja totalmente transmitida à parede do poço desde o momento que o maciço entre em contato com o fluido.

A fase de transmissão de pressão permite ainda estimar o coeficiente de permeabilidade do material com base na curva de crescimento de pressão da base através do programa FPORO conforme descrito no item 4.3.2.1.

\subsubsection{Fase de Difusão de Íons}

O objetivo desta fase é simular a interação físico-química do folhelho em contato com os fluidos de perfuração base água, impondo condições de pressão in situ.

A fase de difusão de íons inicia-se quando as pressões de topo e base do corpo de prova se igualam e se mantêm constantes, ou seja, ocorre a ausência do gradiente de pressão hidráulica. Nesta etapa, mantém-se as pressões nos 
reservatórios e substitui-se o fluido no topo do corpo de prova por um fluido de interesse; para o caso desta dissertação, introduz-se um fluido salino. A introdução de um gradiente químico, mantendo-se o gradiente hidráulico constante, acarreta no surgimento de um fluxo osmótico da água que sai da região menos concentrada (base) para a região mais concentrada (topo), diminuindo assim a pressão na base. Devido ao gradiente de concentração imposto, o fenômeno de difusão de íons será observado simultaneamente no transporte dos íons do reservatório de topo para o reservatório de base, elevando-se a concentração da base ao longo do ensaio. Esta variação de pressão na base do corpo de prova (PP. Base) pode ser monitorada pelo transdutor de pressão localizado no reservatório inferior.

\subsubsection{Parâmetros de Transporte}

\subsubsection{Permeabilidade}

O programa FPoro desenvolvido por Frydman \& Fontoura (1999), baseia-se no método dos elementos finitos e considera equações básicas de fluxo de água e íons devido a gradientes hidráulicos e químicos, chegando a uma formulação que acopla efeitos químicos, hidráulicos e mecânicos.

O programa permite diferentes modos de análise, nos quais se incluem a análise transiente e a análise físico-química. Na etapa de transmissão de pressão, o ajuste numérico dos dados experimentais pode fornecer uma estimativa do coeficiente de permeabilidade dos corpos de prova. Para isto, a análise transiente é adotada considerando-se o material isotrópico, necessitando assim, somente do módulo de Young $(E)$ e do coeficiente de Poisson $(v)$. Desta forma, executa-se o programa com diferentes valores para o coeficiente de permeabilidade até que a curva de crescimento de pressão na base seja similar à observada experimentalmente.

A metodologia é apresentada em detalhes por Muniz et al. (2004 e 2005). Mais informações sobre o programa podem ser encontradas em Frydman \& Fontoura (2001), Araújo (2002), Garcia (2003) e Pastor (2001).

\subsubsection{Coeficiente de Reflexão Experimental}

A metodologia proposta por van Oort et al. (1995), Tan et l. (2002), Ewy \& Stankovich (2002) e Al-Bazali (2005) para obtenção do coeficiente de reflexão

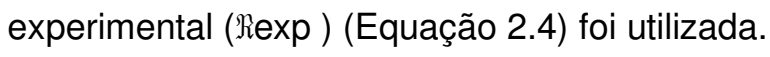


A pressão osmótica experimental $\left(\Delta P_{o s m}\right)$ é obtida ao final da etapa de difusão de íons, sendo igual à diferença da pressão do topo do corpo de prova em relação à pressão da base quando esta permanecer constante.

Segundo Meléndez (2010), a configuração do equipamento e a metodologia de ensaio adotada que utiliza água no reservatório inferior, permitem que a atividade química do fluido de poro do folhelho $\left(A_{f h}\right)$ seja considerada igual a atividade química da água. Logo a equação 2.2 é reformulada e descrita como a Equação (4.2) abaixo:

$$
\Pi=\frac{R T}{V_{w}} \ln \left(A_{f}\right)
$$

Onde:

$\Pi$ = pressão osmótica teórica gerada pelo fluido de perfuração em contato com o folhelho (Equação 2.2)

$R=$ constante universal dos gases $(0,082 \mathrm{I} . \mathrm{atm} / \mathrm{mol} . \mathrm{K})$

$T=$ temperatura absoluta $(\mathrm{K})$

$V_{w}=$ volume parcial molar da água $(0,018 \mathrm{I} / \mathrm{mol})$

$A_{f}=$ atividade química da solução salina utilizada

A atividade química de uma solução é definida como a razão entre a pressão de vapor da água medida nesta solução e a pressão de vapor da água pura, e é numericamente igual à umidade relativa do ar em uma câmara fechada contendo esta solução (Chenevert, 1970, 1990).

O equipamento utilizado para medição da atividade química foi o termohigromêtro da marca Testo Smart (Figura 4.10) pertencente ao LIRF (Laboratório de Interação Rocha-Fluido) do Grupo de Tecnologia e Engenharia de Petróleo (GTEP) do Departamento da Engenharia Civil da PUC-Rio.

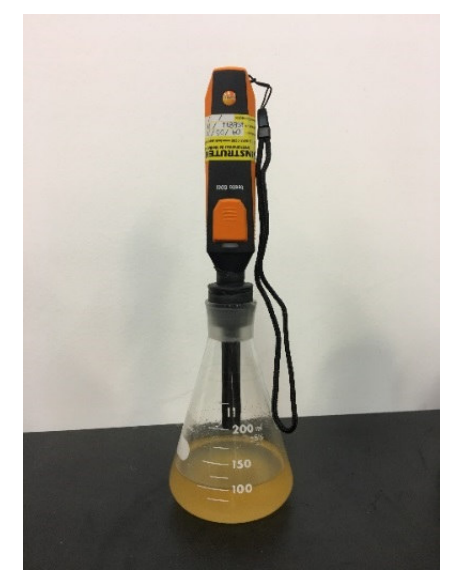

Figura 4.10 - Ensaio para obter a atividade química da solução. 
Neste caso, o fluido de interesse é inserido no interior de um erlenmeyer onde permanece hermeticamente fechado. Após um período de estabilização é medida a umidade relativa do ar que é numericamente igual à atividade química do mesmo.

\subsubsection{Análise e Resultado}

Definida a metodologia dos ensaios e o tratamento dos resultados experimentais, procede-se a realização dos ensaios nas células de difusão.

As quatro amostras de uma polegada dos respectivos folhelhos CP-A, CP$B, C P-C$ e CP-D foram ensaiadas simultaneamente nas quatro células de difusão disponíveis no LIRF. A montagem do corpo de prova e as fases de ensaio seguem o procedimento descrito por Meléndez (2010). A Figura 4.11 apresenta o corpo de prova devidamente preparado para ensaio na célula de difusão.

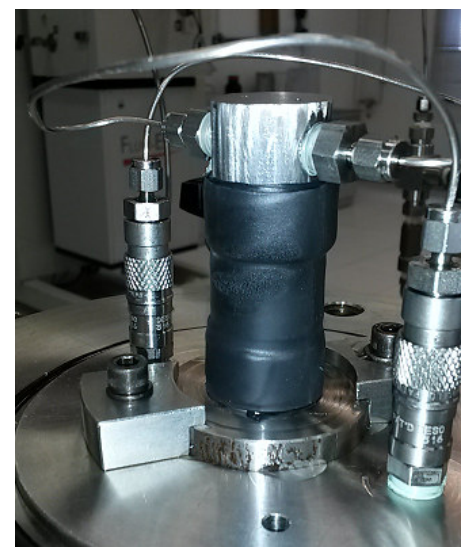

Figura 4.11 - Corpo de prova na célula de difusão.

\subsubsection{Fase de Saturação e Adensamento}

Os corpos de prova foram colocados sequencialmente nas quatro células de difusão e deu-se início à fase de saturação. No processo, os corpos de prova foram submetidos inicialmente a uma pressão confinante ( $P$. Confinante) de $1000 \mathrm{kPa}$ e a uma contrapressão (PP. Topo e PP. Base) de $500 \mathrm{kPa}$. Em sequência, a pressão confinante e a contrapressão foram elevadas em estágios de $500 \mathrm{kPa}$ mantendo-se a tensão efetiva de $500 \mathrm{kPa}$ constante, até a saturação ser obtida, condição observada no valor final do parâmetro B próximo a 1.

Finalizada a saturação, os corpos de prova foram adensados sob pressão confinante de 12MPa e contrapressão de 5MPa por 24 horas. 


\subsubsection{Fase de Transmissão de Pressão e Permeabilidade}

Terminada a fase de adensamento, iniciou-se a fase de transmissão de pressão. As Figuras 4.12, 4.13 e 4.14 apresentam as variações da pressão confinante (P.Confinante), da pressão na base (PP.Base) e da pressão no topo do corpo de prova (PP.Topo) dos CP's ao longo desta fase, assim como o ajuste numérico aos dados experimentais. Vale ressaltar que o CP-B e o CP-C apresentaram um comportamento bastante similar na fase de transmissão de pressão e por este motivo estão sendo figurados em um mesmo gráfico.

Conforme descrito no item 4.3.2.1, os ajustes numéricos dos dados experimentais obtidos nesta fase, através do programa FPORO, fornecem uma estimativa do coeficiente de permeabilidade dos corpos de prova ensaiados. $O$ coeficiente de Poisson $(v)$ e o módulo de Young $(E)$ adotados foram obtidos a partir do SEST por meio de correlações dos perfis de tempo de trânsito conforme Equações (3.7) e (3.8), cujo valores estão representados na Tabela 4.7.

A Tabela 4.7 apresenta ainda os valores de permeabilidade absoluta obtidos através do ajuste numérico para cada corpo de prova. O CP-A possui maior permeabilidade quando comparado com os demais. Os CP-B e CP-C apresentam valores de permeabilidade bem próximos devido à similaridade de comportamento na fase de transmissão de pressão; contudo conforme os ensaios de porosimetria de injeção de mercúrio, porosidades interconectadas diferentes. Já o CP-D possui a menor permeabilidade bem como menor porosidade interconectada.

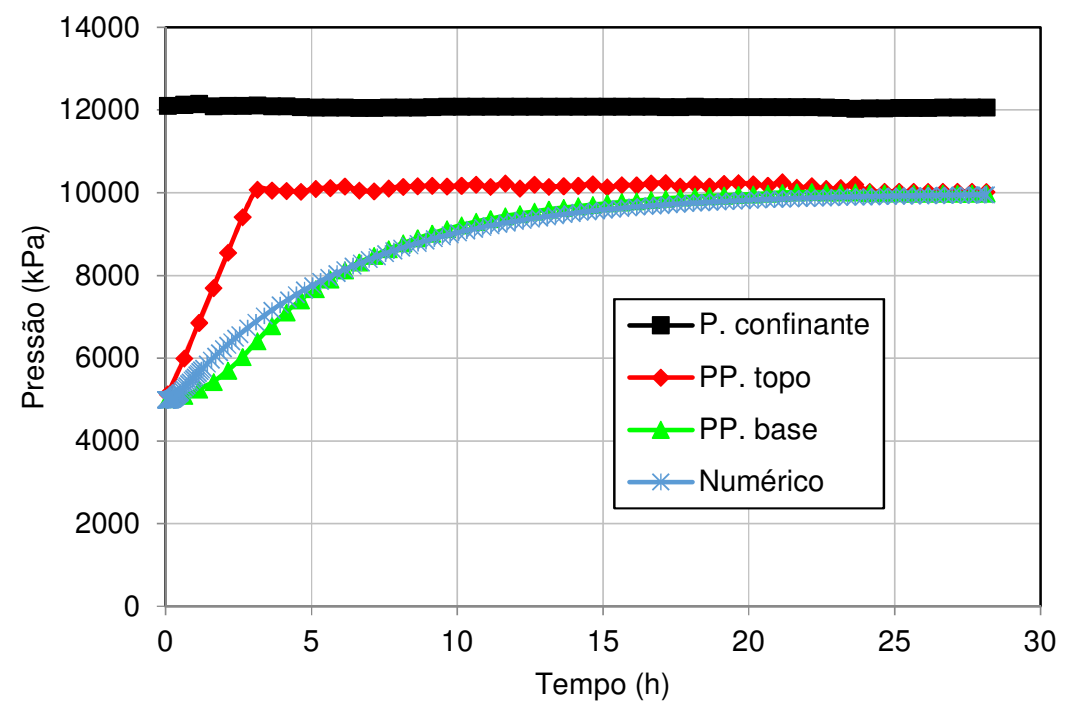

Figura 4.12 - Transmissão de pressão com água do CP-A (Relatório Técnico, 2018 - Projeto de Pesquisa e Desenvolvimento "Soluções em Folhelhos"). 


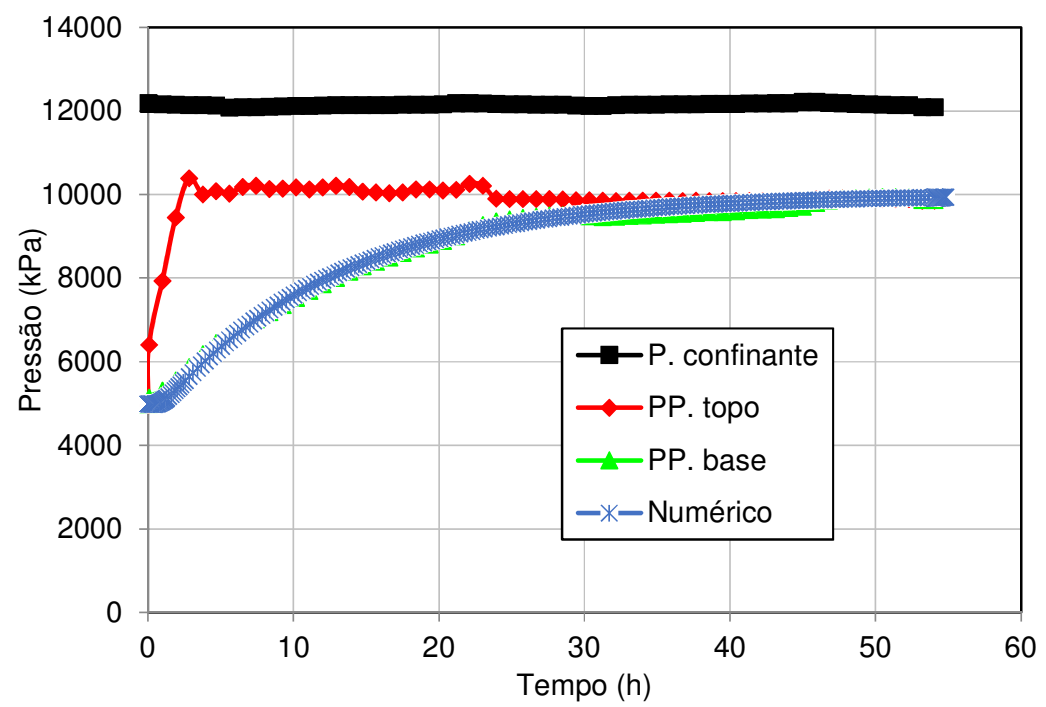

Figura 4.13 - Transmissão de pressão com água do CP-B e CP-C (Relatório Técnico, 2018 - Projeto de Pesquisa e Desenvolvimento "Soluções em Folhelhos").

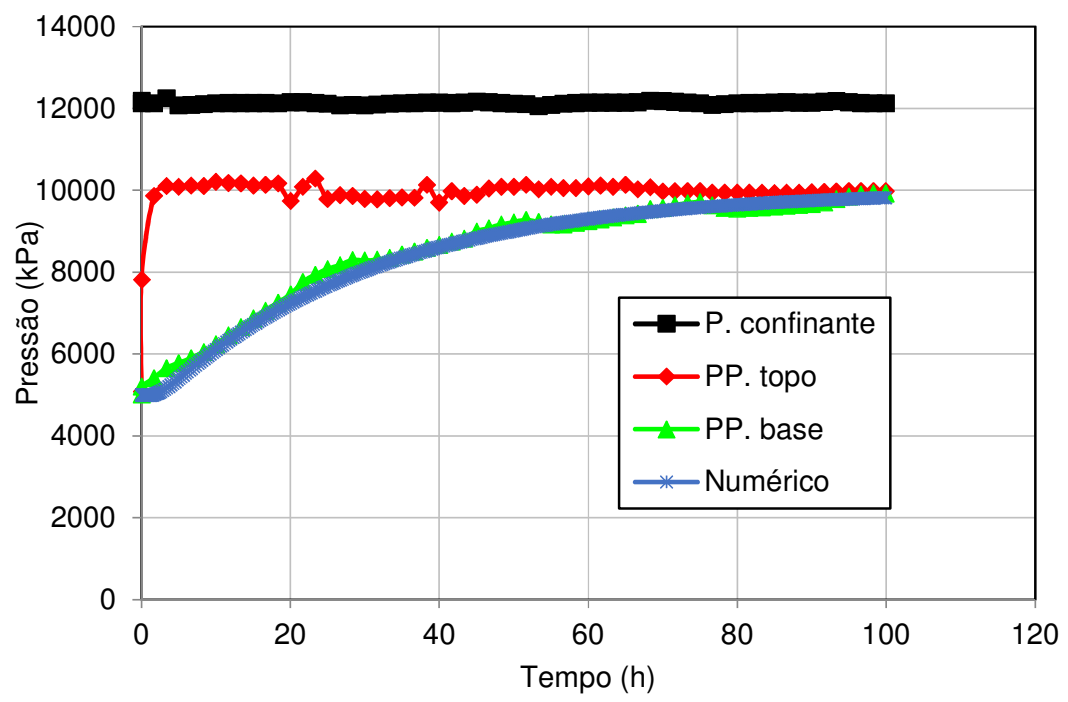

Figura 4.14 - Transmissão de pressão com água do CP-D (Relatório Técnico, 2018 - Projeto de Pesquisa e Desenvolvimento "Soluções em Folhelhos"). 
Tabela 4.7 - Valores da permeabilidade obtidos no ensaio de transmissão de pressão (Relatório Técnico, 2018 - Projeto de Pesquisa e Desenvolvimento "Soluções em Folhelhos").

\begin{tabular}{ccccc} 
Amostra & CP-A & CP-B & CP-C & CP-D \\
\hline Profundidade (m) & 5084 & 5135 & 5193 & 5336 \\
\hline Coef. Poisson & 0,31 & 0,32 & 0,29 & 0,33 \\
\hline Módulo Young (psi) & 4200882,33 & 3133588,37 & 4728298,68 & 3031999,59 \\
\hline Permeabilidade (m²) & $3,10 \mathrm{E}-21$ & $1,65 \mathrm{E}-21$ & $1,59 \mathrm{E}-21$ & $7,20 \mathrm{E}-22$ \\
\hline $\begin{array}{c}\text { Permeabilidade (mD) } \\
\text { Porosidade }\end{array}$ & $3,14 \mathrm{E}-06$ & $1,67 \mathrm{E}-06$ & $1,61 \mathrm{E}-06$ & $7,30 \mathrm{E}-07$ \\
\hline \begin{tabular}{c} 
interconectada (\%) \\
\hline
\end{tabular} & 6,38 & 6,53 & 5,85 & 5,72 \\
\hline
\end{tabular}

\subsubsection{Fase de Difusão de Íons e Coeficiente de Reflexão}

A fase de difusão de íons foi realizada utilizando os fluidos de soluções salinas para os respectivos corpos de prova de acordo com a Tabela 4.8, onde a marcação com o símbolo "x" representa os ensaios realizados.

Durante todo o ensaio, o fluido circulou com vazão constante de $0,2 \mathrm{~mL} / \mathrm{min}$.

Tabela 4.8 - Indicação dos ensaios realizados na fase de difusão de íons.

\begin{tabular}{ccccc}
\hline Fluido & CP-A & CP-B & CP-C & CP-D \\
\hline 1 & - & $\mathrm{X}$ & $\mathrm{X}$ & - \\
$\mathbf{2}$ & - & $\mathrm{X}$ & $\mathrm{X}$ & $\mathrm{X}$ \\
$\mathbf{3}$ & $\mathrm{X}$ & - & - & - \\
\hline
\end{tabular}

As Figuras 4.15 a 4.20 apresentam as variações das pressões ao longo da fase de difusão de íons para os CP's em estudo. 


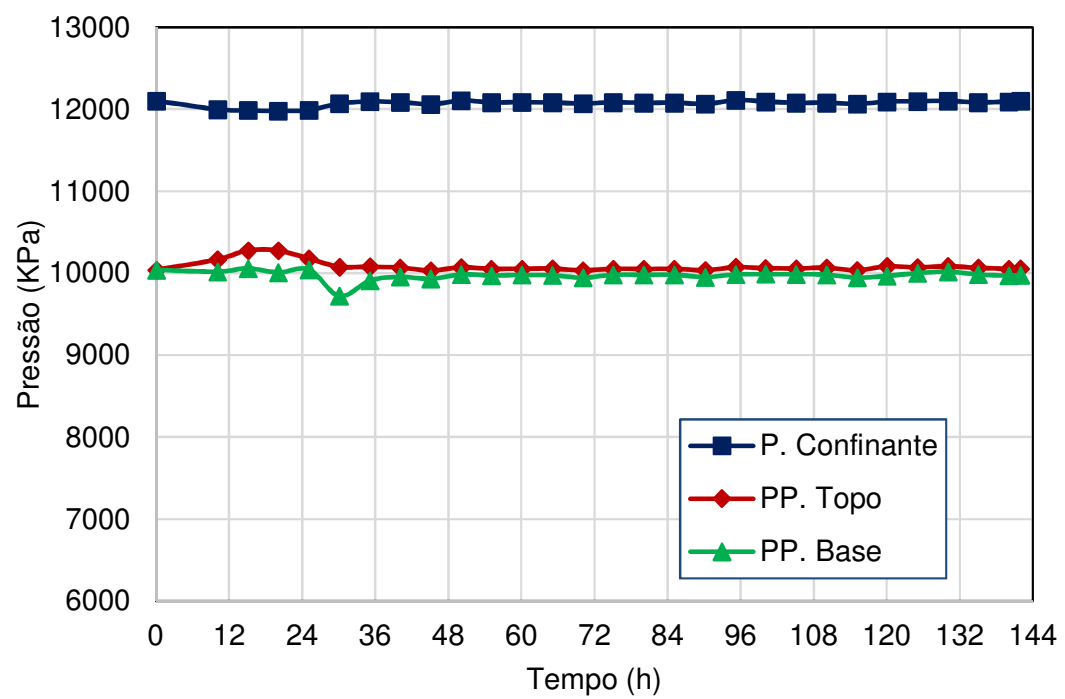

Figura 4.15 - Fase da difusão de íons do CP-A submetida ao fluido 03 (Relatório Técnico, 2018 Projeto de Pesquisa e Desenvolvimento "Soluções em Folhelhos").

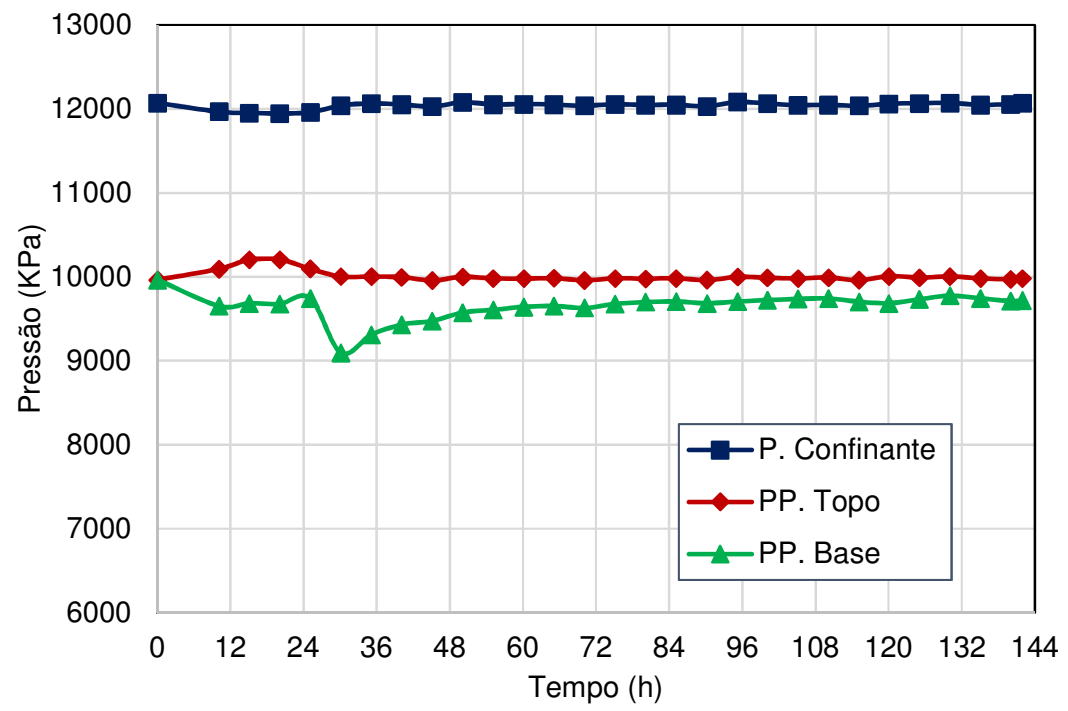

Figura 4.16 - Fase da difusão de íons do CP-B submetida ao fluido 01 (Relatório Técnico, 2018 Projeto de Pesquisa e Desenvolvimento "Soluções em Folhelhos"). 


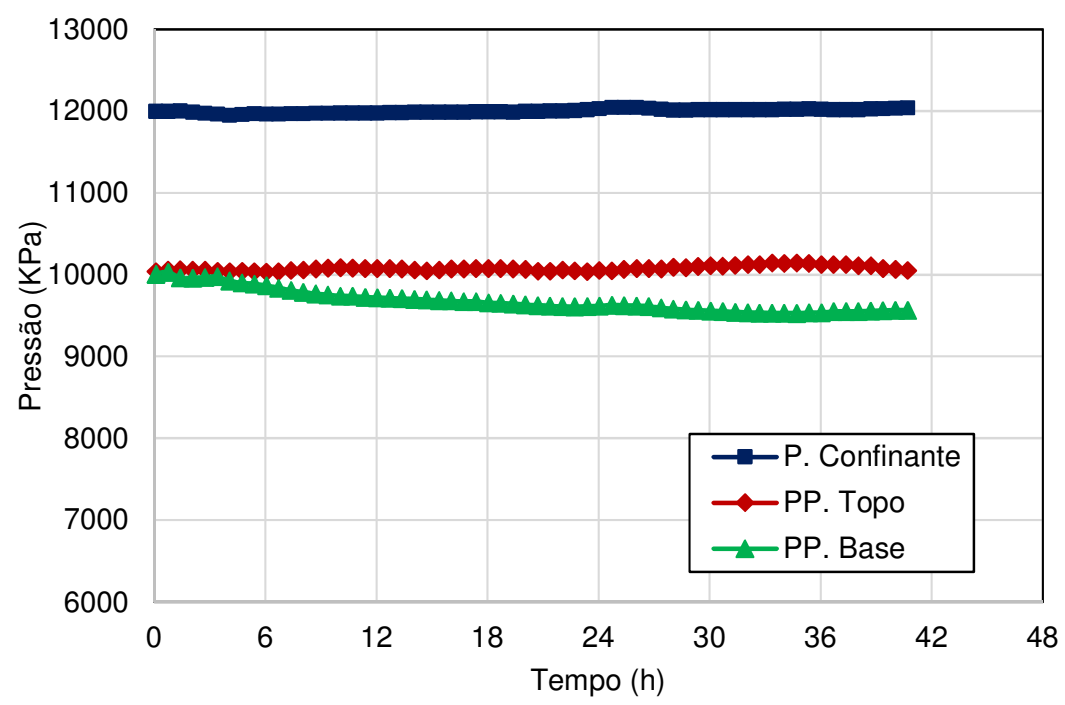

Figura 4.17 - Fase da difusão de íons do CP- B submetida ao fluido 02 (Relatório Técnico, 2018 Projeto de Pesquisa e Desenvolvimento "Soluções em Folhelhos").

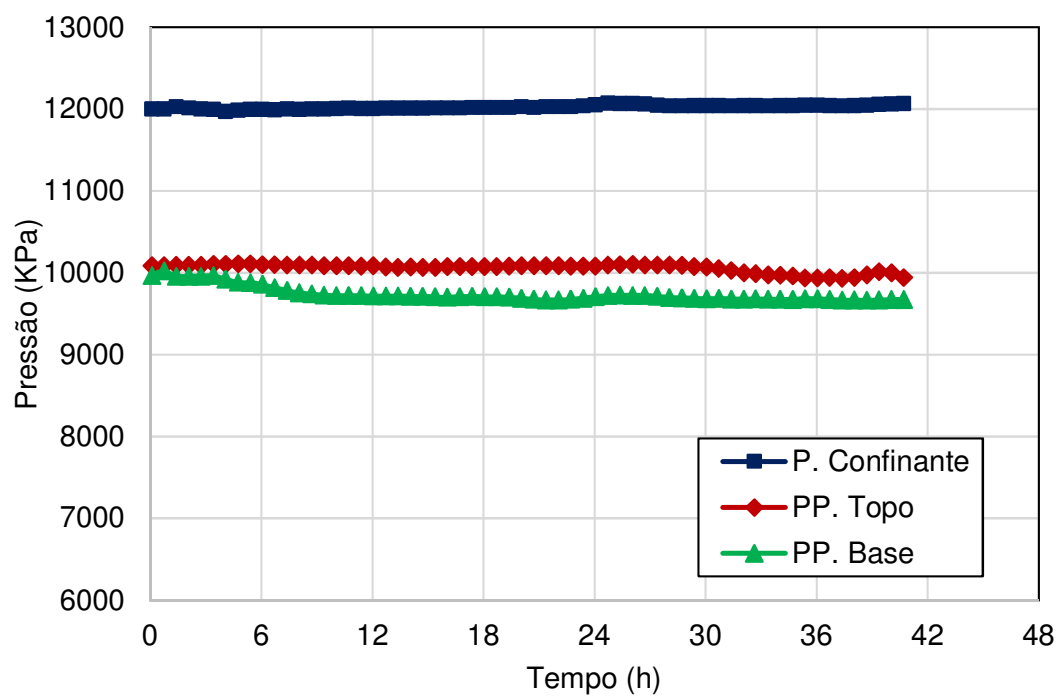

Figura 4.18 - Fase da difusão de íons do CP-C submetida ao fluido 01 (Relatório Técnico, 2018 Projeto de Pesquisa e Desenvolvimento "Soluções em Folhelhos"). 


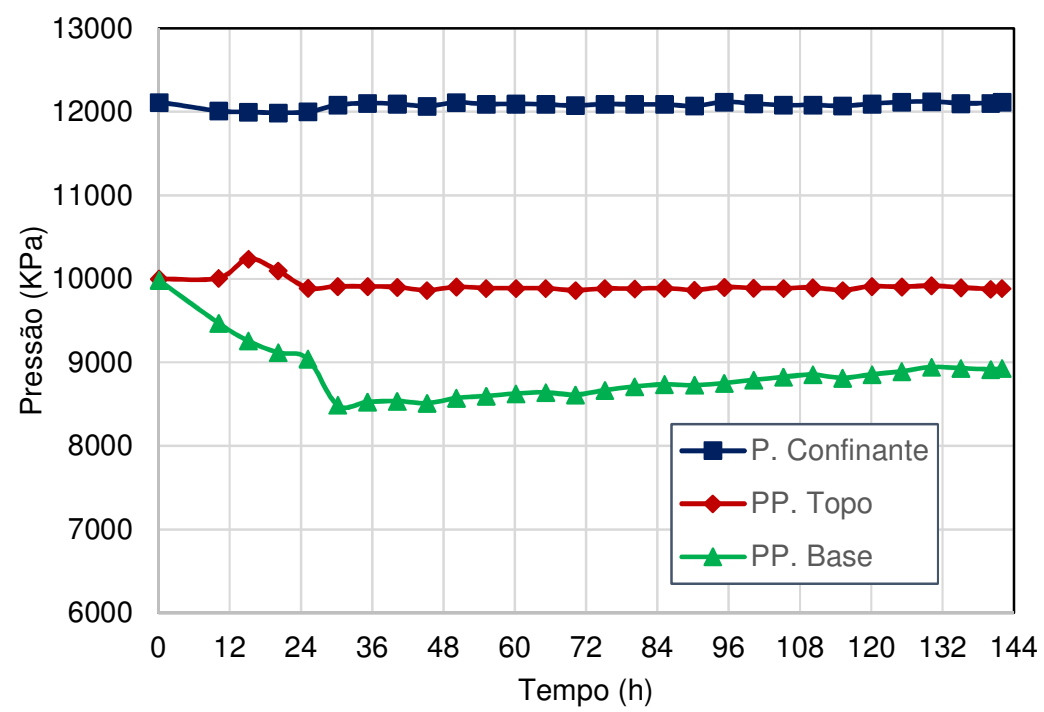

Figura 4.19 - Fase da difusão de íons do CP-C submetida ao fluido 02 (Relatório Técnico, 2018 -

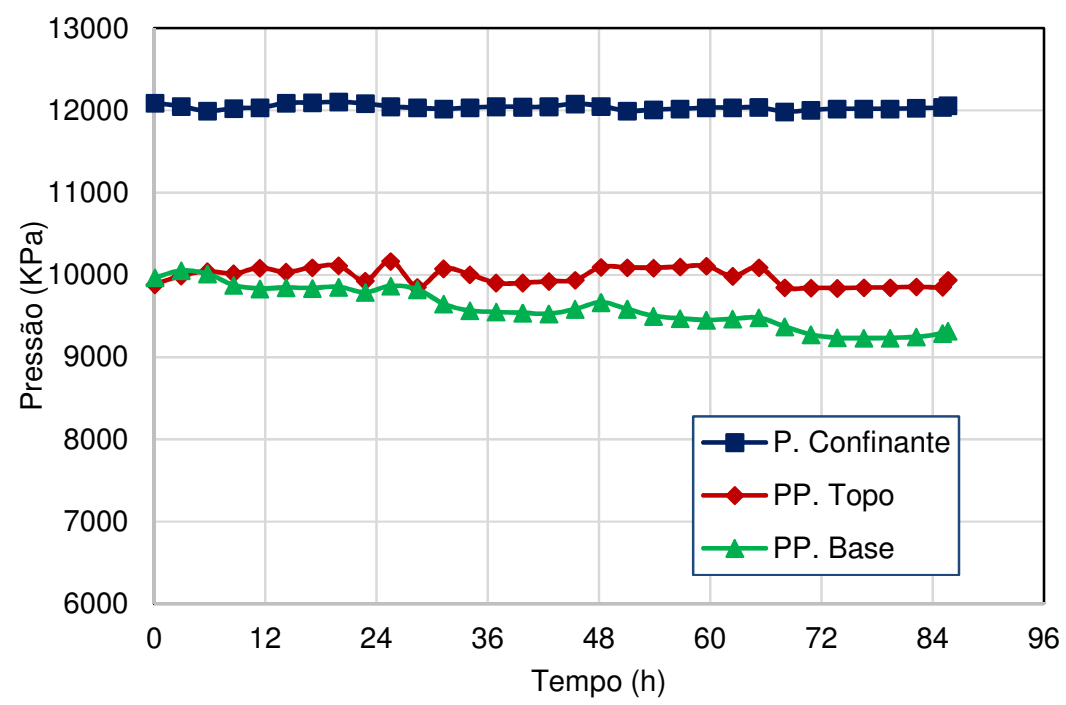

Figura 4.20 - Fase da difusão de íons do CP-D submetida ao fluido 02 (Relatório Técnico, 2018 Projeto de Pesquisa e Desenvolvimento "Soluções em Folhelhos"). 
Finalizada a fase de difusão de íons nos corpos de prova, é possível obter os coeficientes de reflexão para cada ensaio realizado, conforme descrito no item 4.3.2.2. A Tabela 4.9 apresenta os resultados da atividade química (Af) de cada solução utilizada, a pressão osmótica teórica (П), a pressão osmótica gerada experimentalmente $(\triangle \mathrm{Posm})$ e por fim o coeficiente de reflexão experimental ( $R$ exp) para cada corpo de prova.

Tabela 4.9 - Valores dos parâmetros obtidos após os ensaios de difusão.

\begin{tabular}{c|c|c|c|c|c|c}
\hline & CP-A & \multicolumn{2}{|c|}{ CP-B } & \multicolumn{2}{|c|}{ CP-C } & CP-D \\
\hline Fluido & 03 & 01 & 02 & 01 & 02 & 02 \\
\hline Af & 0,99 & 0,88 & 0,89 & 0,88 & 0,89 & 0,89 \\
\hline П (kPa) & - & 18130,52 & 16281,08 & 18130,52 & 16281,08 & 16281,08 \\
\hline posm (kPa) & 71,00 & 263,03 & 522,64 & 393,33 & 1030,81 & 608,99 \\
Rexp (\%) & 0,00 & 1,45 & 3,21 & 2,17 & 6,33 & 3,74 \\
\hline
\end{tabular}

Primeiramente, verifica-se que a atividade química obtida do fluido 03 (água do mar) teve valor aproximado igual a um. Assim, conforme descrito no Capítulo 2, quando o valor da atividade química do fluido é igual a um, ou seja, quando o valor da atividade química do fluido é igual ao valor da atividade química do folhelho, não ocorre fluxo osmótico e, consequentemente pressão osmótica. $O$ gráfico da difusão de íons para o CP-A (Figura 4.15) confirma essa evidência através do baixo valor da pressão osmótica experimental apresentada onde a pressão de topo é aproximadamente igual à pressão de base. Simultaneamente, o coeficiente de reflexão é igual a zero; em outras palavras, o soluto e o solvente podem fluir livremente através da membrana e por fim acarretar em problemas de instabilidade do poço. Em vista disso, a água do mar não pode ser utilizada como um fluido de perfuração, principalmente em regiões de folhelho e, por este motivo, a indústria a utiliza somente nas fases iniciais de perfuração do poço.

Observa-se que ambos os corpos de prova CP-B e CP-C, quando submetidos ao fluido 02, o qual é constituído por uma maior concentração de solução salina, apresentam maiores valores de coeficientes de reflexão experimental quando comparados ao fluido 01. Comprovando que, de fato, o aumento da salinidade pode influir para estabilidade de poços em folhelhos.

Paralelamente, através da comparação dos corpos de prova submetidos ao mesmo fluido, observa-se que para ambos os fluidos 01 e 02, o CP-B apresenta o menor coeficiente de membrana experimental. Este resultado estaria relacionado, possivelmente, à maior porosidade interconectada constatada através do ensaio de porosimetria por injeção de mercúrio. 


\section{4 \\ Considerações Finais}

Inicialmente, foram realizados ensaios de caracterização das quatro amostras dos folhelhos provenientes de diferentes profundidades do poço P-001.

Uma primeira avaliação na distribuição granulométrica sugere que o folhelho CP-B apresenta uma menor porcentagem de material fração areia quando comparado com as demais amostras. Já a amostra CP-C apresentou a menor porcentagem de material fração argila.

As análises químicas dos constituintes dos folhelhos mostraram que ambos os folhelhos são constituídos basicamente pelos minerais quartzo, calcita com possíveis presenças de muscovita, pirita e clorita, além de minerais acessórios e estruturas não identificadas.

Os ensaios de porosimetria por injeção de mercúrio indicaram que as amostras apresentaram distribuição de tamanho de poros bastante similar. Contudo, os CP-B e CP-D apresentaram, respectivamente, maior e menor valores de porosidade interconectada em relação as demais amostras.

Finalizada a campanha de caracterização dos folhelhos, pode-se ter uma idéia inicial do comportamento esperado das amostras em contato com os fluidos de perfuração, ou seja, do coeficiente de reflexão baseado em revisões da literatura.

Fontoura et al. (2007), por exemplo, sugerem que o coeficiente de reflexão é mais influenciado pela distribuição de tamanho de poros do que pelo conteúdo argilomineral. As menores medianas de diâmetros de poros e as maiores porcentagens de microporos fazem que o folhelho em contato com o fluido de perfuração atue como uma barreira que restringe a entrada de íons e água dentro da sua estrutura, o que significa maiores pressões osmóticas geradas no contato fluido-rocha e maiores valores de coeficiente de reflexão. Esta tendência é confirmada pelo CP-B que apresenta menores valores de coeficientes de reflexão com maior porosidade interconectada quando comparado com os demais folhelhos.

Para fins comparativos, a Tabela 4.10 apresenta um resumo dos parâmetros obtidos na caracterização e nos ensaios nas células de difusão. 
Tabela 4.10 - Resumo dos parâmetros obtidos nos ensaios de caracterização e difusão (Relatório Técnico, 2018 - Projeto de Pesquisa e Desenvolvimento "Soluções em Folhelhos").

Laboratório

\section{Amostra Profundidade Permeabilidade Porosidade Fluido Coef Reflexão}

(m)

(mD)

(\%)

(\%)

\begin{tabular}{ccccccc}
\hline CP-A & 5084 & $3,14 \mathrm{E}-06$ & 6,38 & 03 & - \\
\hline \multirow{2}{*}{ CP-B } & \multirow{2}{*}{5135} & \multirow{2}{*}{$1,67 \mathrm{E}-06$} & \multirow{2}{*}{6,53} & 01 & 1,45 \\
\cline { 5 - 7 } & & & & \multirow{2}{*}{5,85} & 02 & 3,21 \\
\hline CP-C & \multirow{2}{*}{5193} & $1,61 \mathrm{E}-06$ & 5,85 & 02 & 2,17 \\
\hline CP-D & 5336 & $7,30 \mathrm{E}-07$ & 5,72 & 02 & 3,33 \\
\hline
\end{tabular}

As campanhas de ensaios realizadas comprovam que a água do mar (fluido 03) não pode ser utilizada para perfuração de fases mais avançadas dos poços, principalmente em regiões de folhelhos, pois não ocorre a geração de pressão osmótica e, consequentemente, não há coeficiente de reflexão. Em outras palavras, quando o folhelho é submetido à água do mar, problemas de instabilidade do poço podem ocorrer.

Comprovou-se ainda que o aumento da salinidade influi no aumento do coeficiente de membrana e, consequentemente, para estabilidade de poços em folhelhos.

A partir da obtenção dos parâmetros de transporte de massa, foram desenvolvidas simulações com o SEST, cujo resultados e análises aparecem contidas no Capítulo 5. 


\section{5 Análise de Estabilidade considerando a Interação Rocha- Fluido}

\section{1 Introdução}

Durante a perfuração através de formações argilosas, as interações físicoquímicas e mecânicas que acontecem ao redor do poço entre o folhelho e o fluido de perfuração podem ter impacto na estabilidade. Apesar das características de resistência iniciais da rocha serem determinadas pela mineralogia, sua mudança com o tempo pode ser controlada pelas propriedades do fluido e técnicas de perfuração usadas.

O forte impacto dos problemas de estabilidade sobre os custos de perfuração, associado à relativa facilidade da incorporação de aditivos nos fluidos de perfuração, sem dúvida alguma têm tornado os efeitos químicos os mais estudados no comportamento de folhelhos (Araújo,2005).

Com intuito de aprimorar a eficiência dos fluidos base água, isto é, torná-los tão eficientes quanto os fluidos base óleo em relação às interações químicas com os folhelhos, o objetivo deste capítulo é analisar o comportamento dos folhelhos expostos a diferentes soluções salinas (a fim de simular os fluidos de perfuração à base de água) através da análise de estabilidade do poço considerando efeitos de interação físico-química a partir dos parâmetros de transporte de massa obtidos no Capítulo 4, visando esclarecer de que maneira as propriedades físicoquímicas podem influenciar na estabilidade de poços.

\section{2 Metodologia}

A análise de estabilidade pontual do poço considerando efeitos de interação físico-química foi determinada através do software de sistema de estabilidade de poços SEST (Sistema de ESTabilidade versão 5.72) criado pelo GTEP da PUCRio em conjunto com a PETROBRAS cujo principal objetivo é a avaliação da variação do gradiente de colapso inferior e, consequentemente, a variação da janela operacional na estabilidade do poço. 
Diferentemente da análise de estabilidade descrita no Capítulo 3 desta dissertação, cujo modelo elástico é adotado, a metodologia para determinar a análise de estabilidade considerando efeito físico-químico seguiu a sequência de cálculo do SEST adotando o modelo poroelástico com acoplamento químico para situações isotérmicas, ou seja, o fluido de perfuração possui a mesma temperatura da rocha. Portanto os efeitos térmicos não foram considerados nesta dissertação.

A solução foi desenvolvida por Ghassemi e Diek (2003), tomando como base as equações já estabelecidas por Detounay e Cheng (1993) e Cui et al. (1997), posteriormente modificada por Araújo (2005). Nesta solução são resolvidas as equações para fração de massa do soluto (concentração), pressão de poros e tensões. Por se tratar de um problema transiente, a solução das equações é obtida através da transformação de Laplace e invertida para o domínio do tempo através de um algoritmo numérico.

Mais informações sobre a formulação das equações utilizadas pelo programa podem ser obtidas no manual teórico do SEST e Araújo (2005).

A escolha do modelo poroelástico permite a análise da variação dos valores da janela operacional conforme o tempo evolui, pois diferentemente do modelo elástico, considera a presença do fluido no meio poroso como agente influente na distribuição de tensões ao redor do poço.

Segundo Araújo (2005), a presença destes fluidos nos poros, fissuras ou fraturas, alteram de modo significativo a resposta aos carregamentos mecânicos aplicados. Nos folhelhos, os efeitos poroelásticos podem impactar drasticamente a estabilidade de um poço devido às suas baixas permeabilidades. Numa análise poroelástica da estabilidade de um poço em folhelho, utilizando fluido base água, a pressão do fluido de perfuração exerce dois tipos de carregamento sobre as rochas perfuradas. No primeiro, a tensão total radial na parede do poço é igual à pressão do fluido de perfuração. Enquanto no segundo, a pressão de poros na parede do poço também é igual à pressão do fluido de perfuração. Um conceito já bem estabelecido é que o aumento da pressão do fluido de perfuração reduz o risco de ocorrência de colapsos (rupturas por cisalhamento) enquanto aumentase o risco de fraturas (rupturas por tração).

Quando são utilizados modelos elásticos para a determinação da janela de estabilidade de um poço, assume-se que esta permanece constante ao longo do tempo. Todavia, como já foi mencionado anteriormente, os efeitos poroelásticos podem alterar significativamente os resultados, como o fechamento da janela operacional à medida que o tempo evolui. 
Além de adotar o modelo poroelástico para gerar a análise de estabilidade, é necessário incorporar no SEST os parâmetros de propriedade hidromecânica e de propriedade físico-química descritos na Tabela 5.1 e adotar valores de tempo no qual o poço aberto é exposto ao fluido de perfuração, a fim de verificar a variação ao longo do tempo da janela de estabilidade.

Vale ressaltar que os parâmetros hidromecânicos podem ser obtidos tanto por correlações utilizadas pelo próprio programa conforme descrito no Capítulo 3 , quanto por ensaios de laboratório ou provenientes de trabalhos publicados na literatura. Para o caso desta dissertação, a análise é feita em dois cenários: no primeiro, os parâmetros hidromecânicos adotados são obtidos por correlações do SEST; no segundo, os parâmetros de permeabilidade e porosidade adotados são oriundos dos ensaios de laboratório, conforme Capítulo 4.

É importante notar que parâmetros como a geometria do poço (profundidade vertical, inclinação, azimute e diâmetro), tensões in situ e pressões de poros também são levados em conta na análise de estabilidade, sendo os dois últimos calculados conforme sequência de cálculos do SEST descritas no Capítulo 3 desta dissertação.

Como metodologia para alargamento da janela operacional de estabilidade, a utilização da área plastificada é utilizada. O termo área plastificada refere-se à razão entre a área da rocha ao redor da parede do poço que sofreu ruptura por cisalhamento e a área do poço. Assim, a rocha ao redor do poço é representada por uma malha constituída por triângulos, conforme a Figura 5.1.

Por fim, o programa calcula e retorna com o valor do gradiente de colapso inferior da profundidade de estudo cujo objetivo é verificar implicitamente os impactos da geração da pressão osmótica sobre o campo de pressão de poros e de tensões ao redor do poço e, diretamente, o impacto sobre a janela de estabilidade neste ponto. 
Análise de Estabilidade considerando a Interação Rocha-Fluido

Tabela 5.1 - Parâmetros necessário para cálculo pontual da janela operacional considerando efeitos de interação físico-química.

\begin{tabular}{|c|c|}
\hline Propriedades HidroMecânica & Propriedades Físico-Química \\
\hline Resistência à Tração & $\begin{array}{l}\text { Coeficiente de Reflexão ou } \\
\text { Eficiência de Membrana }\end{array}$ \\
\hline Resistência à Compressão & Coeficiente de Inchamento \\
\hline Ângulo de Atrito & Coeficiente de Difusão do Soluto \\
\hline Coeficiente de Poisson & Densidade do Fluido da Formação \\
\hline Coeficiente de Biot & Temperatura da Formação \\
\hline Módulo de Young & $\begin{array}{c}\text { Concentração de Soluto do Fluido } \\
\text { de Perfuração }\end{array}$ \\
\hline Densidade dos Grãos & Concentração Soluto na Rocha \\
\hline Permeabilidade & Tipo de Sal \\
\hline Porosidade & $\begin{array}{l}\text { Coeficiente de Dissociação do } \\
\text { Soluto }\end{array}$ \\
\hline Viscosidade & Massa Molar do Soluto \\
\hline
\end{tabular}

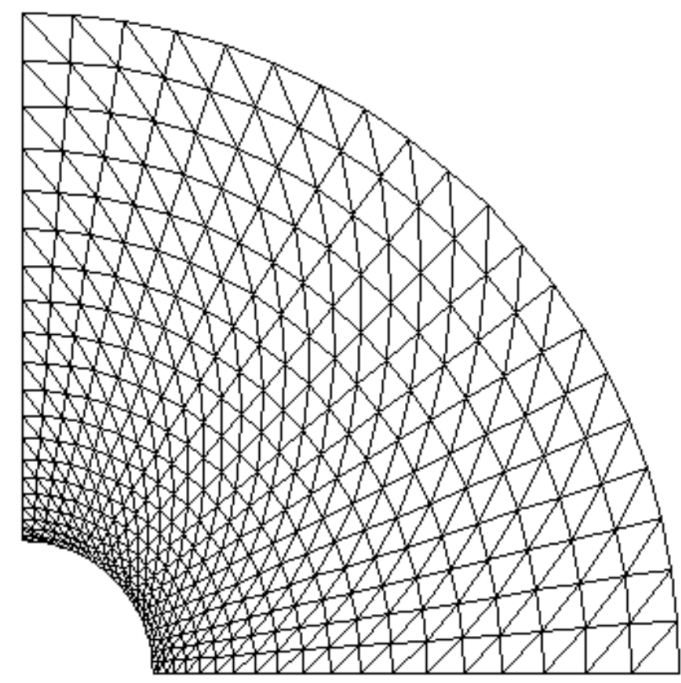

Figura 5.1 - Malha utilizada para calcular a área plastificada ao redor do poço (Araújo, 2005). 


\section{3}

\section{Análise e Resultado}

A fim de verificar os impactos dos efeitos físico-químicos na estabilidade de poços em folhelho, é tomado o caso do poço exploratório P-001 com base na metodologia proposta.

As profundidades de estudo são provenientes das análises das amostras de folhelho em laboratório descritas no Capítulo 4, as quais foram submetidas a diferentes soluções salinas a fim de simular os fluidos de perfuração à base de água e obter os parâmetros de transporte de massa necessários para gerar esta análise de estabilidade.

A primeira etapa da análise é realizada utilizando o modelo elástico e fluido penetrante. Esta etapa representa apenas a condição limite, na qual a difusão de pressão do fluido de perfuração para o interior do folhelho já alcançou o regime permanente.

Em seguida, o modelo poroelástico com acoplamento químico é adotado, com o objetivo de verificar a variação ao longo do tempo da janela de estabilidade. Os intervalos de tempo de exposição adotados são: 1 hora, 24horas, 10 dias, 30 dias e 60 dias.

Considerando o folhelho como a rocha em estudo, situações envolvendo os parâmetros em função da composição e profundidade na qual se encontra foram modeladas.

Conforme descrito anteriormente, foram criados dois cenários cujo objetivo é de caráter comparativo. No primeiro cenário, os valores dos parâmetros hidromecânicos adotados são obtidos por correlações do SEST (Capítulo 3) e no segundo, os parâmetros de permeabilidade e porosidade são adotados a partir dos ensaios de difusão e porosimetria por injeção de mercúrio realizados em laboratório, descritos no Capítulo 4.

Para ambos os cenários, os parâmetros físico-químicos tais como, coeficiente de reflexão ou eficiência de membrana, concentração de soluto do fluido de perfuração e tipo de sal são, também, provenientes dos ensaios de laboratório realizados. Os valores de coeficiente de difusão do soluto igual a 1,6E$10 \mathrm{~m}^{2} / \mathrm{s}$ e o coeficiente de inchamento no valor de 1160psi foram assumidos por serem normalmente utilizados em análises do Centro de Pesquisa da PETROBRAS.

Aplicando a metodologia citada para alargamento da janela operacional, adotou-se uma área plastificada de $15 \%$ ao redor do poço e obteve-se um 
Análise de Estabilidade considerando a Interação

Rocha-Fluido

aceitável alargamento da janela de estabilidade. Destaca-se aqui que foi utilizado o critério de ruptura de Mohr-Coulomb.

As Tabelas 5.2, 5.3 e 5.4 apresentam os valores de cada parâmetro adotado como dado de entrada para a análise de estabilidade de acordo com as profundidades $5135 \mathrm{~m}, 5193 \mathrm{~m}$ e $5336 \mathrm{~m}$, respectivamente, do poço em estudo.

Assumindo tais parâmetros e os intervalos de tempo adotados, as Tabelas 5.5, 5.6 e 5.7 apresentam, respectivamente, a variação dos valores de colapso inferior correspondente ao tempo de exposição do folhelho ao fluido de perfuração nas profundidades $5135 \mathrm{~m}, 5193 \mathrm{~m}$ e $5336 \mathrm{~m}$. Para fins comparativos, as Tabelas 5.5, 5.6 e 5.7 também apresentam os valores de colapso inferior adotando o modelo elástico para dois casos: no primeiro caso, o fluido é considerado como não penetrante (fluido base óleo) - simulando o caso do Capítulo 3 desta dissertação. Já no segundo caso, o fluido é considerado como penetrante (fluido base água) a fim de representar a condição limite, conforme já descrito anteriormente.

Primeiramente, são observados nas Tabelas 5.5 e 5.7 que os valores de colapso inferior aumentam conforme tempo de exposição do folhelho ao fluido de perfuração, ou seja, diminuem a janela operacional e, consequentemente, a estabilidade do poço. Este comportamento confirma e enfatiza a importância de considerar os efeitos de interação rocha-fluido na estabilidade do poço quando este é perfurado por fluidos de perfuração base água.

Já na Tabela 5,6, observa-se um comportamento oposto: os valores de colapso inferior diminuíram conforme tempo de exposição do folhelho ao fluido de perfuração, ou seja, aumentaram a janela operacional. Portanto, é possível concluir que a interação rocha-fluido, neste caso, foi satisfatória e contribuiu para o aumento de estabilidade do poço.

Em todas as profundidades analisadas (Tabela 5.5, Tabela 5.6 e Tabela 5.7), foram observados que a variação dos valores de coeficiente de reflexão e das concentrações salinas dos fluidos adotados não influenciaram no aumento da janela operacional, ou seja, na diminuição dos valores de gradiente de colapso inferior. Isto porque a variação dos parâmetros adotados foi relativamente pequena. Portanto, para que fosse notória a influência do aumento da salinidade e, consequentemente, do aumento do coeficiente de reflexão na estabilidade do poço, seria necessária a adoção de uma maior concentração salina do segundo fluido de perfuração.

Observa-se, ainda, que os valores de colapso inferior, para ambos os Cenários simulados, não apresentaram grandes variações quando comparados a 
Análise de Estabilidade considerando a Interação

uma mesma profundidade, mesmo tempo de exposição e mesma composição de fluido. Portanto, a análise cujos os parâmetros hidromecânicos são obtidos por correlações a partir dos perfis corridos do poço no programa SEST é validada, uma vez que representam valores bem próximos aos analisados e obtidos das amostras em laboratório.

Paralelamente, através da Tabela 5.6, observa-se que a análise elástica considerando fluido penetrante apresentou valor mínimo de gradiente de colapso inferior e, consequentemente, um falso alargamento da janela operacional. Em outras palavras, esta análise não apresenta valores de colapso inferior nos quais, de fato, os folhelhos apresentam conforme o tempo. Caso o projeto do poço considere tal valor como limite inferior da janela operacional e o projetista, portanto, adote um peso de fluido próximo ao colapso inferior, ocorreria instabilidade na profundidade $5193 \mathrm{~m}$ caso a cimentação não venha a ser realizada em menos de 60 dias.

Por outro lado, na Tabela 5.7 a análise elástica considerando fluido penetrante apresentou valores conservadores, isto é, valores de gradientes de colapso maiores em relação aos valores obtidos através da análise poroelástica. Assim, adotar unicamente a análise elástica para um projeto de estabilidade de um poço com perfuração de fluidos base água pode gerar instabilidade do poço, uma vez que esta pode apresentar valores de gradiente de colapso inferiores ao real, enfatizando novamente a importância de analisar a estabilidade do poço conforme o tempo de exposição do folhelho ao fluido de perfuração.

Em relação às análises considerando fluidos não penetrantes (base óleo), observa-se que estes apresentaram comportamentos satisfatórios somente na profundidade $5336 \mathrm{~m}$, pois agem de maneira a aumentar a janela operacional devido aos valores de colapso inferior serem menores quando comparados aos valores da análise poroelástica para fluidos penetrantes (base água).

Já nas profundidades 5135m (Tabela 5.5) e 5193m (Tabela 5.6) observa-se, respectivamente, valores de gradiente de colapso inferior iguais aos do fluido não penetrante e uma diminuição dos valores de colapso inferior conforme o tempo de exposição do folhelho ao fluido de perfuração. Concluindo, assim, que os fluidos salinos adotados para estas profundidades se mostraram tão e, até mesmo, mais eficazes que os fluidos não penetrantes (base óleo) adotados no Capítulo $3 \mathrm{e}$ podem atuar numa melhoria da estabilidade do folhelho devido aos seus efeitos físico-químicos.

Por fim, quando comparados os valores de gradiente de colapso entre as profundidades para a mesma composição de fluido, observa-se que na 
Análise de Estabilidade considerando a Interação

profundidade de $5193 \mathrm{~m}$, onde a amostra (CP-C) ensaiada em laboratório obteve maior coeficiente de reflexão, os valores de gradiente de colapso inferior foram menores, ou seja, ocorreu menor interação rocha-fluido, como o esperado.

Tabela 5.2 - Dados de entrada para análise de estabilidade na profundidade 5135m do poço P001.

\begin{tabular}{|c|c|c|c|}
\hline \multirow{4}{*}{$\begin{array}{c}\text { Geometria } \\
\text { do poço }\end{array}$} & Profundidade vertical & 5135 & $\mathrm{~m}$ \\
\hline & Inclinação & 0 & o \\
\hline & Azimute & 0 & $\underline{\circ}$ \\
\hline & Diâmetro do poço & $81 / 2$ & pol \\
\hline \multirow{4}{*}{$\begin{array}{l}\text { Tensões } \\
\text { in situ }\end{array}$} & Tensão vertical ( $\sigma \mathrm{v})$ & 13054,07 & psi \\
\hline & Tensão horizontal maior $(\sigma H)$ & 11412,55 & psi \\
\hline & Tensão horizontal menor ( $\sigma \mathrm{h})$ & 11412,55 & psi \\
\hline & Pressão de poros (Pp) & 7963,81 & psi \\
\hline \multirow{15}{*}{$\begin{array}{c}\text { Propriedades } \\
\text { Hidro- } \\
\text { mecânicas }\end{array}$} & Resistência à tração (ot) & 397,93 & psi \\
\hline & Resistência à compressão (UCS) & 4775,19 & psi \\
\hline & Ângulo de atrito $(\varnothing)$ & 30 & o \\
\hline & Coeficiente de Poisson (v) & 0,32 & \\
\hline & Coeficiente de Biot $(\alpha)$ & 1 & \\
\hline & Módulo de Young (E) & 3133588,37 & psi \\
\hline & Densidade dos Grãos (G) & 2,75 & \\
\hline & Viscosidade $(\mu)$ & 0,3 & $\mathrm{cP}$ \\
\hline & Kf & 2500 & psi \\
\hline & Cenário 1 - SEST & & \\
\hline & Permeabilidade (K) & $3,86 \mathrm{E}-07$ & $\mathrm{mD}$ \\
\hline & Porosidade (n) & 0,1 & \\
\hline & Cenário 2 - Laboratório & & \\
\hline & Permeabilidade (K) & $1,67 \mathrm{E}-06$ & $\mathrm{mD}$ \\
\hline & Porosidade interconectada (n) & 0,0653 & \\
\hline \multirow{15}{*}{$\begin{array}{c}\text { Propriedades } \\
\text { Físico- } \\
\text { Químicas }\end{array}$} & Coeficiente de inchamento $(\omega)$ & 1160 & psi \\
\hline & Coeficiente de difusão do soluto (D) & $1,60 \mathrm{E}-10$ & $\mathrm{~m}^{2} / \mathrm{s}$ \\
\hline & Densidade do fluido de formação ( $\rho f$ ) & 1000 & $\mathrm{Kg} / \mathrm{m}^{3}$ \\
\hline & Temperatura da formação ( $T$ ) & 60 & $\stackrel{\circ}{C}$ \\
\hline & Concentração do soluto na rocha (Csh) & 25,44 & $\mathrm{Kg} / \mathrm{m}^{3}$ \\
\hline & Coeficiente de dissociação do soluto (d) & 1,864 & \\
\hline & Massa molar do soluto (Ms) & 0,0585 & $\mathrm{Kg} / \mathrm{mol}$ \\
\hline & Fluido 01 & & \\
\hline & Concentração do soluto no fluido de perfuração & 100 & $\mathrm{Kg} / \mathrm{m}^{3}$ \\
\hline & Tipo de Sal & $\mathrm{NaCl}$ & \\
\hline & Coeficiente de reflexão ( $\Re)$ & 0,0145 & \\
\hline & Fluido 02 & & \\
\hline & Concentração do soluto no fluido de perfuração & 200 & $\mathrm{Kg} / \mathrm{m}^{3}$ \\
\hline & Tipo de Sal & $\mathrm{NaCl}$ & \\
\hline & Coeficiente de reflexão $(\mathfrak{R})$ & 0,0321 & \\
\hline
\end{tabular}


Análise de Estabilidade considerando a Interação

Tabela 5.3 - Dados de entrada para análise de estabilidade na profundidade 5193m do poço P001

\begin{tabular}{|c|c|c|c|}
\hline \multirow{4}{*}{$\begin{array}{c}\text { Geometria } \\
\text { do poço }\end{array}$} & Profundidade vertical & 5193 & \\
\hline & Inclinação & 0 & $\underline{0}$ \\
\hline & Azimute & 0 & $\underline{0}$ \\
\hline & Diâmetro do poço & $81 / 2$ & pol \\
\hline \multirow{4}{*}{$\begin{array}{l}\text { Tensões } \\
\text { in situ }\end{array}$} & Tensão vertical (бv) & 13266,57 & psi \\
\hline & Tensão horizontal maior $(\sigma H)$ & 11572,8 & psi \\
\hline & Tensão horizontal menor ( $\sigma \mathrm{h})$ & 11572,8 & psi \\
\hline & Pressão de poros (Pp) & 7782 & psi \\
\hline \multirow{15}{*}{$\begin{array}{l}\text { Propriedades } \\
\text { Hidro- } \\
\text { mecânicas }\end{array}$} & Resistência à tração ( $\sigma \mathrm{t}$ ) & 765,17 & psi \\
\hline & Resistência à compressão (UCS) & 9182,07 & psi \\
\hline & Ângulo de atrito $(\varnothing)$ & 30 & $\underline{\circ}$ \\
\hline & Coeficiente de Poisson (v) & 0,29 & \\
\hline & Coeficiente de Biot $(\alpha)$ & 1 & \\
\hline & Módulo de Young (E) & 4728298,68 & psi \\
\hline & Densidade dos Grãos (G) & 2,75 & \\
\hline & Viscosidade $(\mu)$ & 0,3 & $\mathrm{cP}$ \\
\hline & Kf & 2500 & psi \\
\hline & Cenário 1 - SEST & & \\
\hline & Permeabilidade (K) & $3,54 \mathrm{E}-07$ & $\mathrm{mD}$ \\
\hline & Porosidade (n) & 0,09 & \\
\hline & Cenário 2 - Laboratório & & \\
\hline & Permeabilidade (K) & 1,61E-06 & $\mathrm{mD}$ \\
\hline & Porosidade interconectada (n) & 0,0585 & \\
\hline \multirow{15}{*}{$\begin{array}{l}\text { Propriedades } \\
\text { Físico- } \\
\text { Químicas }\end{array}$} & Coeficiente de inchamento $(\omega)$ & 1160 & psi \\
\hline & Coeficiente de difusão do soluto (D) & $1,60 \mathrm{E}-10$ & $\mathrm{~m}^{2} / \mathrm{s}$ \\
\hline & Densidade do fluido de formação ( $\rho f)$ & 1000 & $\mathrm{Kg} / \mathrm{m}^{3}$ \\
\hline & Temperatura da formação (T) & 60 & $\stackrel{\circ}{C}$ \\
\hline & Concentração do soluto na rocha (Csh) & 25,44 & $\mathrm{Kg} / \mathrm{m}^{3}$ \\
\hline & Coeficiente de dissociação do soluto (d) & 1,864 & \\
\hline & Massa molar do soluto (Ms) & 0,0585 & $\mathrm{Kg} / \mathrm{mol}$ \\
\hline & Fluido 01 & & \\
\hline & Concentração do soluto no fluido de perfuração & 100 & $\mathrm{Kg} / \mathrm{m}^{3}$ \\
\hline & Tipo de Sal & $\mathrm{NaCl}$ & \\
\hline & Coeficiente de reflexão ( $(\mathfrak{R})$ & 0,0217 & \\
\hline & Fluido 02 & & \\
\hline & Concentração do soluto no fluido de perfuração & 200 & $\mathrm{Kg} / \mathrm{m}^{3}$ \\
\hline & Tipo de Sal & $\mathrm{NaCl}$ & \\
\hline & Coeficiente de reflexão ( $(\mathfrak{R})$ & 0,0633 & \\
\hline
\end{tabular}


Análise de Estabilidade considerando a Interação

Tabela 5.4 - Dados de entrada para análise de estabilidade na profundidade $5336 \mathrm{~m}$ do poço P001.

\begin{tabular}{|c|c|c|c|}
\hline \multirow{4}{*}{$\begin{array}{c}\text { Geometria } \\
\text { do poço }\end{array}$} & Profundidade vertical & 5336 & $\mathrm{~m}$ \\
\hline & Inclinação & 0 & $\underline{0}$ \\
\hline & Azimute & 0 & $\underline{0}$ \\
\hline & Diâmetro do poço & $81 / 2$ & pol \\
\hline \multirow{4}{*}{$\begin{array}{l}\text { Tensões } \\
\text { in situ }\end{array}$} & Tensão vertical (бv) & 13780,8 & psi \\
\hline & Tensão horizontal maior $(\sigma H)$ & 11969,83 & psi \\
\hline & Tensão horizontal menor ( $\sigma \mathrm{h})$ & 11969,83 & psi \\
\hline & Pressão de poros $(\mathrm{Pp})$ & 8200,74 & psi \\
\hline \multirow{15}{*}{$\begin{array}{c}\text { Propriedades } \\
\text { Hidro- } \\
\text { mecânicas }\end{array}$} & Resistência à tração (ot) & 391,61 & psi \\
\hline & Resistência à compressão (UCS) & 4699,36 & psi \\
\hline & Ângulo de atrito $(\varnothing)$ & 30 & $\underline{0}$ \\
\hline & Coeficiente de Poisson ( $v$ ) & 0,33 & \\
\hline & Coeficiente de Biot $(\alpha)$ & 1 & \\
\hline & Módulo de Young (E) & 3031999,59 & psi \\
\hline & Densidade dos Grãos (G) & 2,75 & \\
\hline & Viscosidade $(\mu)$ & 0,3 & $\mathrm{cP}$ \\
\hline & $\mathrm{Kf}$ & 2500 & psi \\
\hline & Cenário 1 - SEST & & \\
\hline & Permeabilidade (K) & $2,96 \mathrm{E}-07$ & $\mathrm{mD}$ \\
\hline & Porosidade (n) & 0,08 & \\
\hline & Cenário 2 - Laboratório & & \\
\hline & Permeabilidade (K) & $7,30 \mathrm{E}-07$ & $\mathrm{mD}$ \\
\hline & Porosidade interconectada (n) & 0,0572 & \\
\hline \multirow{11}{*}{$\begin{array}{c}\text { Propriedades } \\
\text { Físico- } \\
\text { Químicas }\end{array}$} & Coeficiente de inchamento $(\omega)$ & 1160 & psi \\
\hline & Coeficiente de difusão do soluto (D) & $1,60 \mathrm{E}-10$ & $\mathrm{~m}^{2} / \mathrm{s}$ \\
\hline & Densidade do fluido de formação ( $\rho f$ ) & 1000 & $\mathrm{Kg} / \mathrm{m}^{3}$ \\
\hline & Temperatura da formação $(T)$ & 60 & $\stackrel{\circ}{\mathrm{C}}$ \\
\hline & Concentração do soluto na rocha (Csh) & 25,44 & $\mathrm{Kg} / \mathrm{m}^{3}$ \\
\hline & Coeficiente de dissociação do soluto (d) & 1,864 & \\
\hline & Massa molar do soluto (Ms) & 0,0585 & $\mathrm{Kg} / \mathrm{mol}$ \\
\hline & Fluido 02 & & \\
\hline & Concentração do soluto no fluido de perfuração & 200 & $\mathrm{Kg} / \mathrm{m}^{3}$ \\
\hline & Tipo de Sal & $\mathrm{NaCl}$ & \\
\hline & Coeficiente de reflexão $(\Re)$ & 0,0374 & \\
\hline
\end{tabular}


Análise de Estabilidade considerando a Interação Rocha-Fluido

Tabela 5.5 - Valores do colapso inferior em lb/gal correspondente ao tempo de exposição do folhelho ao fluido de perfuração e ao modelo elástico para fluido não penetrante e para fluido penetrante na profundidade de 5135m (Relatório Técnico, 2018 - Projeto de Pesquisa e Desenvolvimento "Soluções em Folhelhos").

\begin{tabular}{|c|c|c|c|c|}
\hline \multirow{2}{*}{$\mathbf{P V}=\mathbf{5 1 3 5 m}$} & \multicolumn{2}{|c|}{ Cenário 1} & \multicolumn{2}{c|}{ Cenário 2} \\
\cline { 2 - 5 } & $\Re=0.0145$ & $\Re=0.0321$ & $\Re=0.0145$ & $\Re=0.0321$ \\
\hline $\begin{array}{c}\text { Tempo de } \\
\text { Exposição }\end{array}$ & $\begin{array}{c}\text { Conc. } \mathrm{NaCl}: \\
100 \mathrm{~kg} / \mathrm{m}^{3}\end{array}$ & $\begin{array}{c}\text { Conc. } \mathrm{NaCl}: \\
200 \mathrm{~kg} / \mathrm{m}^{3}\end{array}$ & $\begin{array}{c}\text { Conc. } \mathrm{NaCl}: \\
100 \mathrm{~kg} / \mathrm{m}^{3}\end{array}$ & $\begin{array}{c}\text { Conc. } \mathrm{NaCl}: \\
200 \mathrm{~kg} / \mathrm{m}^{3}\end{array}$ \\
\hline 1h (60min) & 9,10 & 9,10 & 9,10 & 9,10 \\
\hline 24H (1440min) & 9,10 & 9,11 & 9,12 & 9,11 \\
\hline 10d (14400min) & 9,12 & 9,13 & 9,12 & 9,15 \\
\hline 30d (43200min) & 9,12 & 9,15 & 9,12 & 9,16 \\
\hline 60d (86400min) & 9,12 & 9,15 & 9,13 & 9,16 \\
\hline \multirow{2}{*}{ Elástico } & \multicolumn{2}{|c|}{ Não Penetrante } & \multicolumn{2}{|c|}{9,10} \\
\cline { 2 - 5 } & \multicolumn{3}{|c|}{ Penetrante } \\
\hline
\end{tabular}

Tabela 5.6 - Valores do colapso inferior em lb/gal correspondente ao tempo de exposição do folhelho ao fluido de perfuração e ao modelo elástico para fluido não penetrante e para fluido penetrante na profundidade de 5193m (Relatório Técnico, 2018 - Projeto de Pesquisa e Desenvolvimento "Soluções em Folhelhos").

\begin{tabular}{|c|c|c|c|c|}
\hline \multirow{2}{*}{$\mathbf{P V}=\mathbf{5 1 9 3 m}$} & \multicolumn{2}{|c|}{ Cenário 1} & \multicolumn{2}{c|}{ Cenário 2} \\
\cline { 2 - 5 } & $\Re=0.0217$ & $\Re=0.0633$ & $\Re=0.0217$ & $\Re=0.0633$ \\
\hline $\begin{array}{c}\text { Tempo de } \\
\text { Exposição }\end{array}$ & $\begin{array}{c}\text { Conc. } \mathrm{NaCl}: \\
100 \mathrm{~kg} / \mathrm{m}^{3}\end{array}$ & $\begin{array}{c}\text { Conc. } \mathrm{NaCl}: \\
200 \mathrm{~kg} / \mathrm{m}^{3}\end{array}$ & $\begin{array}{c}\text { Conc. } \mathrm{NaCl}: \\
100 \mathrm{~kg} / \mathrm{m}^{3}\end{array}$ & $\begin{array}{c}\text { Conc. } \mathrm{NaCl}: \\
200 \mathrm{~kg} / \mathrm{m}^{3}\end{array}$ \\
\hline 1h (60min) & 7,54 & 7,60 & 7,54 & 7,60 \\
\hline 24H (1440min) & 7,46 & 7,47 & 6,79 & 6,80 \\
\hline 10d (14400min) & 6,65 & 6,68 & 5,96 & 5,99 \\
\hline 30d (43200min) & 6,25 & 6,27 & 5,70 & 5,72 \\
\hline 60d (86400min) & 6,01 & 6,05 & 5,56 & 5,61 \\
\hline \multirow{2}{*}{ Elástico } & \multicolumn{2}{|c|}{ Não Penetrante } & \multicolumn{2}{|c|}{5,93} \\
\cline { 2 - 5 } & \multicolumn{3}{|c|}{ Penetrante } \\
\hline
\end{tabular}

Tabela 5.7 - Valores do colapso inferior em lb/gal correspondente ao tempo de exposição do folhelho ao fluido de e ao modelo elástico para fluido não penetrante e para fluido penetrante na profundidade de 5336m (Relatório Técnico, 2018 - Projeto de Pesquisa e Desenvolvimento "Soluções em Folhelhos").

\begin{tabular}{|c|c|c|c|}
\hline \multirow{2}{*}{ PV=5336m } & \multicolumn{2}{|c|}{ Cenário 1 } & Cenário 2 \\
\cline { 2 - 4 } & $\Re=0.0374$ & $\Re=0.0374$ & $\Re=0.0374$ \\
\hline $\begin{array}{c}\text { Tempo de } \\
\text { Exposição }\end{array}$ & $\begin{array}{c}\text { Conc. NaCl: } \\
100 \mathrm{~kg} / \mathrm{m}^{3}\end{array}$ & $\begin{array}{c}\text { Conc. } \mathrm{NaCl}: \\
200 \mathrm{~kg} / \mathrm{m}^{3}\end{array}$ & $\begin{array}{c}\text { Conc. NaCl: } \\
200 \mathrm{~kg} / \mathrm{m}^{3}\end{array}$ \\
\hline 1h (60min) & 9,29 & 9,30 & 9,30 \\
\hline 24H (1440min) & 9,35 & 9,35 & 9,44 \\
\hline 10d (14400min) & 9,54 & 9,57 & 9,68 \\
\hline 30d (43200min) & 9,63 & 9,66 & 9,75 \\
\hline 60d (86400min) & 9,70 & 9,72 & 9,80 \\
\hline \multirow{2}{*}{ Elástico } & \multicolumn{2}{|c|}{ Não Penetrante } & 9,30 \\
\cline { 2 - 4 } & \multicolumn{2}{|c|}{ Penetrante } & 9,79 \\
\hline
\end{tabular}




\section{4}

\section{Considerações Finais}

A fim de analisar os efeitos físico-químicos dos fluidos salinos ao longo do tempo na estabilidade do poço, foi gerada a análise de estabilidade no SEST tomando como estudo de caso três profundidades do poço P-001.

As propriedades das diferentes soluções salinas elaboradas no Capítulo 4, bem como os parâmetros de transporte de massa como o coeficiente de reflexão, porosidade e permeabilidade, foram inseridos na análise de estabilidade.

Da mesma forma, com intuito comparativo, foram realizadas análises considerando tais parâmetros de transporte de massa previstos pelo próprio programa e descritos no Capítulo 3.

As semelhanças entre os cenários simulados indicaram a validação da análise cujos os parâmetros hidromecânicos são obtidos por correlações a partir dos perfis corridos do poço no programa SEST.

Salienta-se ainda a importância da consideração físico-química no comportamento do poço ao longo do tempo. Foi verificada a variação da janela de estabilidade ao longo do tempo incorporando na análise o modelo poroelásticos com acoplamento físico-químico. Segundo Azevedo (2005), esses efeitos em folhelhos são muito importantes, devido às baixas permeabilidades dessas rochas que, além de manter os excessos de pressão de poros devido ao carregamento não drenado por longos períodos de tempo, não permitem a formação de reboco na parede do poço quando de utiliza fluidos base água e, portanto, estabelecem um processo transiente de difusão de pressão de poros do fluido de perfuração para o interior da rocha. Sendo esta difusão de pressão, a principal responsável pelo fechamento da janela operacional, pois eleva a pressão de poros e, consequentemente, reduz as tensões efetivas.

A análise foi finalizada considerando que o que melhor representa a situação real de perfuração em folhelhos é a atuação conjunta dos efeitos físico-químicos ao longo do tempo quando estes são expostos a fluidos base água.

Os resultados mostraram que os fluidos salinos hipotéticos propostos foram satisfatórios quando comparado ao fluido base óleo utilizado no Capítulo 3 desta dissertação, pois resultaram no aumento da janela operacional e, consequentemente, na estabilidade do poço. Comprovou-se que um dimensionamento adequado da concentração salina do fluido de perfuração resulta em um controle da estabilidade do poço. Em outras palavras, para obter 
Análise de Estabilidade considerando a Interação

Rocha-Fluido

estabilidade de poços em folhelhos é necessário muito mais do que apenas dimensionar a pressão do fluido de perfuração.

Por fim, com base nos casos analisados, pôde-se observar que os parâmetros que influenciam no estado de tensão e, consequentemente, na estabilidade do poço são: o tipo de fluido de perfuração, seu peso e fatores característicos da formação. 


\section{6 Conclusão e Sugestão para Trabalhos Futuros}

\section{1 \\ Conclusão}

Durante a perfuração de um poço, fatores mecânicos e físico-químicos atuam conjuntamente e contribuem para os problemas de instabilidade das formações perfuradas. A relevância da análise dos dados de perfuração como fonte de conhecimento e aprendizado para elaboração de novos projetos é evidenciada inicialmente por diversos autores.

A metodologia proposta de realização de uma retroanálise do poço, em função dos eventos de perfuração identificados no BDP, foi representativa o suficiente para avaliar as condições de instabilidade e identificar os seus possíveis agentes causadores.

A elaboração do gráfico da profundidade versus tempo acoplados aos eventos de perfuração, bem como ao perfil Caliper e a litologia, permitiram reconstruir o histórico de perfuração do poço e obter informações essenciais de quando, em quais profundidades e em quais formações os eventos tendem a ocorrer e em como estes influenciam na instabilidade do poço.

A análise de estabilidade considerando o modelo elástico gerada pelo software SEST permitiu concluir que as causas do problema de instabilidade identificado não foram de origem mecânica, uma vez que o peso de fluido estava dentro dos limites estabelecidos pela janela operacional. Com base na relação de problemas e causas descrita por Rabelo (2008), algumas hipóteses de causas para o arrombamento constatado podem ser levantadas, como: ação mecânica da coluna de perfuração ou reatividade da formação ao fluido de perfuração utilizado.

Finda a retroanálise do poço e com o intuito de propor um fluido que apresente melhor desempenho econômico para futuras operações em poços correlacionados, amostras de testemunhos de diferentes profundidades foram submetidas a soluções salinas de diferentes concentrações a fim de simular e analisar a influência da interação rocha-fluido na estabilidade dos folhelhos quando estes são expostos a fluidos de perfuração base água ao longo do tempo. 
A realização da caracterização das amostras dos folhelhos permitiu compreender os fenômenos de transferência de massa entre o folhelho e o fluido de perfuração. A distribuição de tamanho de poros, por exemplo, é função inversa dos coeficientes de reflexão, isto é, menores medianas de diâmetros de poros e maiores porcentagens de microporos geram maiores pressões osmóticas no contato rocha-fluido e maiores valores de coeficiente de reflexão.

Os parâmetros de transporte obtidos através dos ensaios das amostras nas células de difusão foram satisfatórios. Obteve-se uma boa correlação do coeficiente de reflexão com o aumento da salinidade do fluido de perfuração. Posteriormente, estes foram implementados na análise de estabilidade no SEST.

A fim de analisar os efeitos físico-químicos das soluções salinas ao longo do tempo na estabilidade do poço, a análise de estabilidade adotou o modelo poroelástico e investigou os valores de gradiente de colapso inferior.

Foi verificada, inicialmente, a variação dos valores do colapso inferior e, consequentemente da janela operacional, concluindo que a estabilidade do poço é, de fato, dependente do tempo. Enfatiza-se, portanto, que os efeitos físicoquímicos da interação rocha-fluido devem ser levados em consideração no projeto de fluidos de perfuração e no gerenciamento de instabilidade de folhelhos pois representam a situação real de perfuração quando estes são expostos à fluidos base água.

As semelhanças entre os cenários simulados indicaram a validação da análise cujos os parâmetros hidromecânicos são obtidos por correlações a partir dos perfis corridos do poço no programa SEST.

Os resultados mostraram que os fluidos salinos hipotéticos propostos foram satisfatórios quando comparado ao fluido base óleo utilizado no poço, pois resultaram no aumento da janela operacional e, consequentemente, na estabilidade do poço. Comprovou-se que um dimensionamento adequado da concentração salina do fluido de perfuração resulta em um controle da estabilidade do poço. Assim, para obter estabilidade de poços em folhelhos é necessário muito mais do que apenas dimensionar a pressão do fluido de perfuração.

\subsection{Sugestão para Trabalhos Futuros}

Sugere-se que trabalhos futuros avaliem a instabilidade do poço por meio da modelagem tridimensional, conforme metodologia proposta por Argote (2012) a fim de adquirir conhecimento geomecânico não somente do poço, mas do campo 
em estudo. Implementar junto a modelagem tridimensional, os efeitos físicoquímicos para toda extensão do poço.

Recomenda-se para futuros trabalhos, realizar uma análise de sensibilidade dos parâmetros de transporte obtidos através de ensaios de interação rocha-fluido em corpos de prova que levem em consideração a anisotropia do material.

Recomenda-se ainda a realização de uma extensa caracterização mineralógica das amostras por meio de ensaios como Difração de Raio X, Capacidade de Troca Catiônica (CTC) e Testes de inchamento, a fim de correlacionar os minerais, bem como seu coeficiente de inchamento, com o comportamento físico-químico ao longo do tempo.

Elaborar um estudo paramétrico, simulando os efeitos físico-químicos em diferentes composições de fluidos para estudo. Adicionando ainda, o estudo da variação da permeabilidade das amostras conforme exposição ao fluido de perfuração e os efeitos térmicos nas análises de interação rocha-fluido. 


\section{Referências bibliográficas}

ARAÚJO, E. M. P. (2002). Influência da Variação da Permeabilidade na Estabilidade de Poços de Petróleo. Dissertação de mestrado, Departamento de Engenharia Civil, Pontifícia Universidade Católica, Rio de Janeiro.

ARAÚJO, E. W. P. (2005). Modelo Acoplado Termo-Químico-Poroelástico para a Análise de Estabilidade de Poços em Folhelhos. Tese de doutorado, Departamento de Engenharia Civil, Pontifícia Universidade Católica, Rio de Janeiro.

AL-BAZALI T. M. (2005). Experimental Study of the Membrane Behavior of Shale During Interaction with Water-Based and Oil-Based Muds. PhD Thesis, University of Texas at Austin.

AL-BAZALI, T. M., KUWAIT, U., ZHANG, J., ATLAS, B., CHENEVERT, M. E., SHARMA, M. M. (2006). Factors Controlling the Membrane Efficiency of Shales when Interacting with Water-Based and Oil-Based Muds. Society of Petroleum Engineers, paper SPE 100735, International Oil \& Gas Conference and Exibition, China, Dec.

AMANULLAH, MD., AL-ARFAJ, MOHAMMED, K., SAUDI, A., ABDULLAH, S. S., ENAMUL, H. ABDULAZEEZ, A. (2014). Chemical and Mechanical Aspects of Wellbore Stability in Shale Formations: A Literature Review. Society of Petroleum Engineers, paper SPE 1716822-MS, Abu Dhabi International Petroleum Exhibition and Conference, UAE, Nov.

ARGOTE, S. M. R. (2012). Modelo Geomecânico Aplicado à Análise de Estabilidade de Poços com Ênfase em Folhelhos. Dissertação de metrado, Departamento de Engenharia Civil, Pontifícia Universidade Católica do Rio de Janeiro.

AZEVEDO, M. S. (2011). Análise geomecânica aplicada à análise de estabilidade de poços. Projeto de Graduação. Curso de Engenharia de Petróleo, Universidade Federal do Rio de Janeiro, Rio de Janeiro.

BAI, M., GUO, Q., JIN, Z. H. (2008). Study of Wellbore Stability due to Drilling Fluid/Shale Interactions. American Rock Mechanics Association, paper ARMA 08-325, 42th US Rock Mechanics Symposium and 2th US Canada Rock Mechanics Symposium, San Francisco, Jun.

BOL, G. M., WONG, S-W, DAVIDSON, C. J., WOODLAND, D. C. (1994). Borehole Instability in Shales. Society of Petroleum Engineers, SPE Drilling \& Completation, Paper SPE-24975. Jun. 
BELLOTTI, P.; GIACCA, D. (1978). Pressure evaluation improves drilling programs. The Oil and Gas Journal.

BROWN, G. AND BRINDLEY, G. W. (1980). X-Ray Diffraction Procedure for Clay Mineral Identification, In: Brindley, G. W., Bronw, G., Cristal structures of clays minerals and their x-ray identification, Mineralogical Society, London

COATES, G.R.; DENOO, S. A. (1981). Mechanical properties program using borehole analysis and Mohr's circle. Society of Petrophysicists \& Well Log Analysts-SPWLA.

CHEN, G. (2001). A Study of Wellbore Stability including poroelastic, chemical and thermal effects. Doctor's dissertation. Faculty of the Graduate School of the University of Texas at Austin, Texas.

CHEN, G., EWY, R., YU, M. (2006). Analytical solutions with ionic flow for a pressure transmission test on shale. Proc. Of 41th US Syposium on Rock Mechanics, Golden, Colorado.

CHENEVERT, M. E. (1970). Shale Control with balanced-activity oilcontinuous muds. Society of Petroleum Engineers, paper SPE 2559, SPE 44th Annual Fail Meeting, Denver.

CHENEVERT, M. E. (1990). Lecture: Diffusion of Water and Ions into Shales. Eurock 1990. Rotterdam, September.

CHOI, S. K., TAN, C. P., FREIJ-AYOUB, R. (2004). A Coupled MechanicalThermal-Phsyco-Chemical Model for the Study of Time-Dependent Wellbore Stability in Shale. CSIRO Petroleum, Australia.

COLLINS, R. E., LORD, M. E., LAKE, L., ROUSE, B. (1989). Measurement of Diffusion Coefficients in Shale. Proc. Int. Symp. on Class I and II Injection Well Technology, UIPC, Dallas, Texas.

DARLEY, H. C. H., GRAY, G. R. (1988). Composition and Properties of Drilling and Completion Fluids. 5th Ed., Gulf Publishing Company, Houston, TX.

DEVILLE, J., FRITZ, B., JARRETT, M. (2011). Development of Water-Based Drilling Fluids Customized for Shale Reservoirs. SPE Drilling and Completion, Dec.

DUARTE, R. G. (2004). Avaliação de Interação Folhelho-Fluido de Perfuração para Estudo de Estabilidade de Poços. Dissertação de mestrado, Departamento de Engenharia Civil, Pontifícia Universidade Católica, Rio de Janeiro.

EWY, R. T. \& STANKOVICH, R. J. (2002). Shale-Fluid Interactions Measured Under Simulated Downhole Conditions. Society of Petroleum Engineers and 
International Society for Rock Mechanics, paper SPE/ISRM 78160, SPE/ISRM Rock Mechanics Conference, Irving, Oct.

FJÆR E., HOLT, R.M., HORSRUD, P. et al. (2008). Petroleum Related Rock Mechanics. $2^{\mathrm{a}}$ Edição, Elsevier Science Publishing Company Inc, New York, USA.

FONTOURA, S. A. B., GAGGIOTTI, K. B., BRAGANÇA, M. J. C., BERTOLINO, L. C. (1999). Shale Characterization. Report GTEP-001/99, submitted to Joint Industry Project Steering Committee, Rio de Janeiro, 37 p.

FONTOURA, S. A. B., MUNIZ E. S. AND LOMBA, R. F. T. (2007). Pressure Diffusion and Ion Diffusion Properties of Terciary Shales. 11th Congress of International Society for Rock Mechanics - The Second Half Century of Rock Mechanics. Taylor \& Francis/Balkema - London. vol 2, pp 1261-1264.

FRYDMAN, M., FONTOURA, S. A. B. (1999). Algorithms for Wellbore Stability in Shales - numerical formulation. Report GTEP-24/1999, submitted to Joint Industry Project Steering Committee, Rio de Janeiro, 49p.

FRYDMAN, M., FONTOURA, S. A. B. (2001). Modeling Aspects of Wellbore Stability In Shales. Society of Petroleum Engineers, paper SPE 69529, Latin American and Caribbean Petroleum Enginnering Conference, Buenos Aires, 8 p.

GARCIA, O. C. C. (2003). Avaliação da Influência da Interação Rocha-Fluido na Estabilidade de Poços. Dissertação de metrado, Departamento de Engenharia Civil, Pontifícia Universidade Católica, Rio de Janeiro.

GARDNER, G.; GARDNER, L.; GREGORY, A. (1974). Formation velocity and density: the diagnostic basis for stratigraphic traps. Geophysics, 1974, Tulsa, Okla. Proceedings... Tulsa, Okla, v.39, n.6, p. 770-780.

HAWKES, C. D., McLELLAN, P. J., RUAN, C., MAURER, W. (2000). Wellbore Instability in Shales: A Review of Fundamental Principles, Physico-Chemical Mechanism in Mud-Shale Interaction and Gri-Funded Research. Gas Research Institute Report Number GRI-99/0025.3.

HE, W., JIMBI, E., CHAMBERLIN, M. (2016). Invasion and Movement of Fluids in Shale Formations and Wellbore Stability. Paper IADC/SPE-178766MS. IADC/SPE Drilling Conference and Exhibition in Fort Worth, Texas, March.

HORSRUD, P.; HOLT, R. M.; SONSTEBO, E. F.; SVANO, G.; BOSTROM, B. (1994). Time dependent borehole stability: Laboratory studies and numerical simulation of different mechanisms in shale. Rock Mechanics in Petroleum Engineering, Delft, Netherlands. Proceedings... Delft, Netherlands: Society of Petroleum Engineers, SPE 28060.

IDAGAWA, L. S. (1990). Estudo do diagnóstico de problemas na perfuração. Dissertação de Mestrado. Departamento de Engenharia de Petróleo, Universidade Estadual de Campinas, São Paulo, 1990. 
KATCHALSKY, A. K. AND CURRAN, P. F. (1965). Non-Equilibrium Thermodynamics in Biophysics. Harvard University Press, Cambridge, 248p.

LAL M. (1999). Shale Stability: Drilling Fluid Interaction and Shales Strength. Society of Petroleum Engineers, paper SPE 54356, Latin American and Caribbean Petroleum Engineering Conference, Venezuela, Apr., 10p.

LOMBA, R. F. T. (1998). Membrane Behavior of Shales and Ionic Solutions. Tese de doutorado, University of Texas, Austin, 238 p.

MACHADO, J. C. V.; OLIVEIRA, M. M. (1986). Concentração Ótima de Cloreto de Potássio para Reduzir a Capacidade de Hidratação de Formações Argilosas. Publicação interna, Petrobras.

MELENDEZ, V. M. A. (2010). Avaliação Experimental dos Parâmetros de Transporte em Folhelhos. Dissertação de mestrado, Departamento de Engenharia Civil, Pontifícia Universidade Católica, Rio de Janeiro.

MCINTYRE, B.; DIXON, R.; MOHAMED, F.; BIRAN, V.; LIU, C.; ISLAM, S. A.; DONALD, J. A. (2009). Wellbore Instability in Forties: Diagnosis of Root Causes for Improved Drilling Performance. Offshore Europe, 2009, Aberdeen, UK.Proceedings... Aberdeen, UK: Society of Petroleum Engineers, SPE 124670.

MCINTYRE, B.; HIBBERT, E. D.; DIXON, R.; KEIR, D.; OROURKE, T.; MOHAMMED, F.; DONALD, J. A.; CHANG, L.; SYED, A.; BIRAN, V. (2009). Managing Drilling Risk in a Mature North Sea Field. Offshore Europe, 2009. Aberdeen, UK. Proceedings... Aberdeen, UK: Society of Petroleum Engineers, SPE 124666.

MIURA, K. (1991). Método para aquisição e representação do conhecimento sobre procedimentos operacionais em serviços de completação de poços marítimos. Dissertação de mestrado, Departamento de Engenharia de Petróleo. Universidade Estadual de Campinas, Campinas.

MIURA, K.; GUILHERME, I. R.; MOROOKA, C. K.; MENDES, J. R. P.(2003). Processing Technical Daily Reports in Offshore Petroleum Engineering - An experience. Journal Advanced Computational Intelligence and Intelligent Informatics. v.7, n.2.

MODY, F. K., HALE, A. H. (1993). Borehole Stability Model to Couple the Mechanics and Chemistry Of Drilling Fluid Shale Interaction. Society of Petroleum Engineers Journal, paper SPE 25728, SPE/IADC Drilling Conference, Amsterdam, Feb., pp. 1093-1101.

MUNIZ, E. S. (2003). Desenvolvimento de Equipamento e Metodologia de Testes para Avaliação da Interação Folhelho-Fluido de Perfuração. Tese de doutorado, Departamento de Engenharia Civil, Pontifícia Universidade Católica, Rio de Janeiro, $174 \mathrm{p}$. 
MUNIZ, C. S. (2005). Interação Fluidos Sintéticos Base Óleo e Base Água e Folhelhos. Dissertação de mestrado, Pontifícia Universidade Católica, Rio de Janeiro, 97 p.

NBR 6502/95 (1995). Rochas e Solos - Terminologia. ASSOCIAÇÃO BRASILEIRA DE NORMAS TÉCNICAS (ABNT).

NES, O-M., BOE, R., SONSTEBO, E. F., GRAN, K., WOLD, S., SAASEN, A., FJOGSTAD, A. (2013). Post-Well Shale-Stability Modeling and History Matching in Norwegian North Sea. Society of Petroleum Engineers, paper SPE150714, SPE Deepwater Drilling and Completions Conference, Galveston, Texas. Jun.

O'BRIEN, D. E.; CHENEVERT, M. E. (1973). Stabilizing Sensitive Shales With Inhibited Potassium-Based Drilling Fluids. SPE Journal of Petroleum Technology, v. 25, n. 9, p. 1089-1100.

OLSEN, H. W., YEARSLEY, E. N., NELSON, R. K. (1990). Chemico-osmosis Versus Diffusion-osmosis. Transportation Research Record, pp.15-22.

OORT, E. V. (1994). A novel technique for the investigation of drilling fluid induced borehole instability in shales. Rock Mechanics in Petroleum Engineering, 1994,Delft, Netherlands. Proceedings... Delft, Netherlands: Society of Petroleum Engineers, SPE 28064.

OSUJI C. E., CHENEVERT M. E., SHARMA M. M. (2008). Effect of Porosity and Permeability on the Membrane Efficiency of Shales. Society of Petroleum Engineers, paper SPE 1163

PASTOR, J. A. S. C. (2001). Modelagem de Reservatórios de Petróleo Utilizando Formulação Acoplada de Elementos Finitos. Tese de doutorado, Pontifícia Universidade Católica, Rio de Janeiro, 167 p.

RABE, C., FONTOURA, S. A. B. (2002). Determinação dos Diâmetros dos Poros de Folhelhos Através da Técnica de Injeção de Mercúrio. Anais do $10^{\circ}$ Congresso Brasileiro de Geologia de Engenharia e Ambiental, Ouro Preto/MG, 25 a 28 de Agosto, pp.78-85.

RABE, C. (2003). Estudo Experimental da Interação Folhelho-Fluido de Perfuração Através de Ensaios de Imersão. Tese de doutorado, Departamento de Engenharia Civil, Pontifícia Universidade Católica, Rio de Janeiro, 290 p.

RABE, C., ARAÚJO E. M. P., GAGGiOTTI, K. V. B., FONTOURA, S. A. B. (2003). Caracterização de um Folhelho da Bacia de Campos a partir de Perfilagem de Poços e Ensaios de Laboratório. $2^{\circ}$ Congresso Brasileiro de P\&D em Petróleo e Gás. Rio de Janeiro.

RABELO, C. A. C. (2008). Uma metodologia para análise de dados de perfuração de poços de desenvolvimento. Dissertação de mestrado. Faculdade de 
Engenharia Mecânica e Instituto de Geociências, Universidade Estadual de Campinas, São Paulo.

Relatório Técnico Parcial 4 (2017). Projeto de Pesquisa e Desenvolvimento "Soluções em Folhelhos" Projeto PETROBRAS-PUC-Rio (GTEP). N ${ }^{\circ}$ 0050.0098223.15.9. SAP 4600501027. Relatório semestral confidencial: abril 2017 - setembro 2017. Rio de Janeiro, Brasil. SIGITEC - Gestão de Investimentos em Tecnologia.

Relatório Técnico (2018). Projeto de Pesquisa e Desenvolvimento "Soluções em Folhelhos" Projeto PETROBRAS-PUC-Rio (GTEP). N ${ }^{\circ}$ 0050.0098223.15.9. SAP 4600501027. Relatório Final Confidencial. Rio de Janeiro, Brasil. SIGITEC Gestão de Investimentos em Tecnologia.

ROCHA, L. A. S., AZEVEDO, C. T. (2007). Projetos de Poços de Petróleo: Geopressões e Assentamentos de Colunas de Revestimentos, 2.ed. Rio de Janeiro: Ed. Interciência, Petrobras.

SANTOS, P. S. (1975). Tecnologia de Argilas Aplicadas às Argilas Brasileiras. Vol. 1 Fundamentos, Ed. Edgard Blücher Ltda. São Paulo.

SEST@-Sistema de ESTabilidade, versão 5.72, (2012). GTEP/PUC-RIO e TEP/CENPES/PETROBRAS.

SCHLEMMER, R., FRIEDHEIM, J. E., GROWCOCK, F. B., BLOYS, J. B., HEADLEY, J. A., POLNASZEK, S. C. (2003). Chemical Osmosis, Shale, and Drilling Fluids. Society of Petroleum Engineers, paper SPE 86912, SPE Drilling \& Completion, December, Vol. 18, No. 4, pp.318-331.

SHEPARD, F. P. (1954). Nomenclature Based on Sand-Silt-Clay Ratios. Journal of Sedimentary Petrology 24, pp.151-158.

SIMPSON, J. P. \& DEARING, H. L., (2000). Diffusion Osmosis-An Unrecognized Cause of Shale Instability. Society of Petroleum Engineers and International Association of Drilling Contractors, paper IADC/SPE 59190, IADC/SPE Drilling Conference, New Orleans, Febr., 2000, pp.1-14.

SKeMPTON, A. W. (1954). The Pore-Pressure Coefficients A and B. Geotechnique, 4, pp. 143-147.

SOARES, J. A. (1992). Um estudo da estabilidade mecânica de poços a partir de perfis geofísicos em formações pouco consolidadas. Dissertação de mestrado. Departamento de geofísica. Universidade Federal do Pará, Belém.

SONE, H. ZOBACK, M. (2013). Mechanical Properties of Shale-Gas Reservoirs Rocks - Part 1: Static and Dynamic Elastic Properties and Anisotropy. Geophysics Journal, Vol 78, No 5, September-October.

STEIGER, R. P. \& LEUNG P. K. (1992). Quantitative Determination of the Mechanical Properties of Shales. SPE Drilling Engineering1 18024. 
STOWE, C., HALLIDAY, W., XIANG, T., CLAPPER, D., MORTON, K., AND HARTMAN, S. (2001). Laboratory Pore Pressure Transmission Testing of Shale. Paper AADDE-01-NC-HO-44, AADE National Drilling Conference, 27-29 March.

SUGUIO, K. (1998). Dicionário de geologia sedimentar e áreas afins. BDC União Editoras S.A.

TAN, C. P., RICHARDS, B. G., RAHMAN, S. S. (1996). Managing physichemical wellbore instability in shales with the chemical potential mechanism. Society of Petroleum Engineers, paper SPE36971, Asia Pacific Oil and Gas Conference, Adelaide, Oct., pp. 107-116.

TAN C. P., RICHARDS, B. G., RAHMAN, S. S. (1997). Effects of swelling and hydrational stress in shales on wellbore stability. Society of Petroleum Engineers, paper SPE38057, Asia Pacific Oil and Gas Conference and Exhibition, Kuala Lumpur. Apr., pp. 345,349.

TAN, C. P., RAHMAN, S. S., CHEN, X. (1998). Wellbore Stability Analysis and Guidelines for Efficient Shale Instability Management. Society of Petroleum Engineers and International Association of Drilling Contractors, paper SPE/IADC 47795, SPE/IADC Asia Pacific Drilling Technology Conference and Exhibition, Indonesia, Sept., 10p.

TAN, C. P., WU, B., MODY, F. K., TARE, U. A. (2002). Development and Laboratory Verification of High Membrane Efficiency Water-Based Drilling Fluids with Oil-Based Drilling Fluid-Like Performance in Shale Stabilization. Society of Petroleum Engineers, paper SPE 78159, SPE/ISRM Rock Mechanics Conference, Irving, Oct., 12p.

TARE, U. A., MODY, F. K., MESE, A. I. (2000). Understanding ChemicalPotential-Related Transient Pore-Pressure Response to Improve Real-Time Borehole (in) Stability. Predictions. SPE/Petroleum Society of CIM 65514, Alberta, 8 p.

TAVARES, R. M. (2006). Interpretação e análise de dados de perfuração em poços de petróleo. Dissertação de mestrado, Departamento de Engenharia de Petróleo. Universidade Estadual de Campinas, São Paulo.

THOMAS, J. E. (2001). Fundamentos de Engenharia de Petróleo. Editora Interciência, 2 ed. Rio de Janeiro 2004, PETROBRAS, 271p.

VAN OORT, E. (1994). A Novel Technique for the Investigation of Drilling Fluid Induced Borehole Instability in Shales. Society of Petroleum Engineers, paper SPE 28064, SPE/ ISRM Rock Mechanics in Petroleum Engineering Conference, Delft, Aug., pp. 293-308.

VAN OORT, E., HALE, A. H., MODY, F. K. (1995). Manipulation of Coupled Osmotic Flows for Stabilization of Shales Exposed to Water-Based Drilling 
Fluids. Society of Petroleum Engineering, paper SPE 30499, SPE Annual Conference \& Exhibition, Dallas, Oct., pp. 22-25.

VAN OORT, E. (1997). Physico-chemical Stabilization of Shale. Society of Petroleum Engineers, paper SPE 37263, SPE International Symposium on Oilfield Chemistry, Houston, Feb., 18-21, pp. 523-538.

VAN OORT, E. (2003). On the Physical and Chemical Stability of Shales. Journal of Petroleum Science and Engineering 38, Elsevier Science B.V, pp. 213235.

VOS, B. E., REIBER F. (2000). The Benefits of Monitoring Torque \& Drag in Real Time. IADC/SPE Asia Pacific Drilling Technology, Kuala Lumpur, Malaysia. Proceedings... Kuala Lumpur, Malaysia: Society of Petroleum Engineers, SPE 62784-MS.

WARD, I., WILliAMSON, R. (1996). Silicate Water Based Muds - A Significant Advance in Water Based Drilling Fluid Technology. Paper presented at the IBC Conference on the prevention of oil discharge from drilling operation, Aberdeen, Jun., 21p.

YARIM, G.; RITCHIE, G. M.; MAY, R. B. A. (2010). Guide to Successful Backreaming: Real-Time Case Histories. SPE Drilling \& Completion, v. 25, n. 1, p. 27-38.

ZHOU, Z., LAW, D. (1998). Swelling Clays in Hydrocarbon Reservoirs: The Bas, The Less, and The Useful. 